\title{
OS TALENTOS DO CORPO: UMA EXPERIÊNCIA DE TRABALHO CORPORAL COM PACIENTES COM TRANSTORNO MENTAL
}

\begin{abstract}
Dissertação apresentada ao Programa de PósGraduação da Escola de Enfermagem da Universidade de São Paulo para obtenção do tíltulo de Mestre em Enfermagem, na área de concentração de Enfermagem Psiquiátrica.
\end{abstract}

Orientadora: Prof ${ }^{a}$ Drª Luciana de Almeida Colvero 
Catalogação na Publicação (CIP)

\section{Biblioteca "Wanda de Aguiar Horta"}

Escola de Enfermagem da Universidade de São Paulo

Tessitore, Eliana Cappelletti.

Os talentos do corpo: uma experiência de trabalho corporal com pacientes com transtorno mental. / Eliana Cappelletti Tessitore. - São Paulo, 2006.

$129 \mathrm{p}$.

Dissertação (Mestrado) - Escola de Enfermagem da Universidade de São Paulo.

Orientadora: $\operatorname{Prof}^{\mathrm{a}} \mathrm{Dr}^{\mathrm{a}}$ Luciana de Almeida Colvero.

1. Fisioterapia 2. Saúde mental 3. Expressão corporal. I. Título. 


\section{DEDICATÓRIA}

À memória de minha mãe, professora dedicada que me ensinou as primeiras letras.

Ao meu pai, que não parou de se preocupar com o andamento do trabalho.

Às razões de minha vida, Enzo e Ricardo, presentes em cada passo, que compreenderam cada momento, muitas vezes opinando e me surpreendendo.

A Douglas, meu irmão, por ter acreditado.

À minha tia Therezinha, enfermeira ímpar que, com seu cuidado e amor, é exemplo de vida.

À minha querida Célia, grande parceira, escolhida como irmã, por ter me escutado, acolhido e mostrado coisas que eu nem imaginava ... 


\section{DEDICATÓRIA ESPECIAL}

À Luciana Colvero, do que as palavras alcançam, um dos presentes que recebi nesses tempos, com quem pude partilhar as inquietações, dúvidas, segredos, desabafos e conquistas ... 


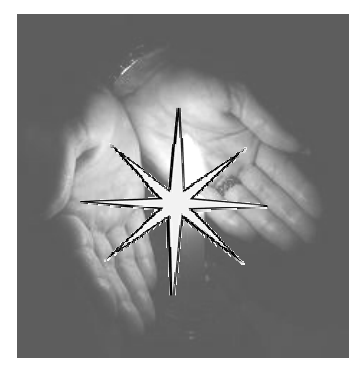

\section{AGRADECIMENTOS}

Como tantos dizem, é bem verdade que não se constrói um trabalho sem a ajuda de muitas pessoas, porque quando percebe, suas inquietações e anseios encarnam em você, nos seus pensamentos, nos seus desejos e no seu cotidiano. Ao novo projeto, juntam-se aqueles que dele tomam conhecimento e partilham sua construção verdadeiramente. Por isso, esse trabalho, embora leve meu nome, pertence a muita gente. Por isso corro o risco de não conseguir registrar todos os que participaram do processo....

Em agradecimento, reverencio a Grande Força do Universo por ter me presenteado com uma resplandecente constelação, composta por todos e, ao mesmo tempo, cada um de vocês, que brilha no céu de minha memória.

Em agradecimento a cada um fiz uma "Estrela de Luz" com o Amor que cria Vida. Ansiosa por entregá-las, enfim, chegou a hora!

Levadas pelo vento do meu pensamento, gostaria que a recebessem e a usassem como um presente para enfeitar seu coração, seu quarto, sua roupa, sua vida...você pode escolher. Num eterno devir, ela pode nunca acabar!

Aos pacientes que estiveram e estão no Grupo Corpo, por buscarem comigo modos de celebrar a vida, sem os quais não haveria jornada.

$1 / 2$ À equipe de profissionais e trabalhadores do Centro de Reabilitação e Hospital, por terem acreditado, acolhido, compreendido, e pela tolerância com essa estrangeira (eu) com quem partilharam seus conhecimentos e espaços. Em especial agradeço Oswaldo Hakiot, que me apresentou ao CRHD, me falou as primeiras palavras de trabalho corporal em saúde mental e me incentivou a cada momento.

À amiga Letícia Reis que partilhou comigo as reflexões, desabafos, frustrações, tristezas, risadas, alegrias e a coordenação do Grupo Corpo.

Ao Dr. Sergio Bettarello pelas valiosas orientações e sugestões em muitas etapas dessa dissertação. 
1 LÀ querida Fabiana Takiuti, que construiu comigo a concepção do Grupo Corpo e durante o ano de 2004 como uma irmã, partilhou cada passo e deixou imensas saudades.

A Ana Lucia Machado e Juarez Furtado pelas importantes sugestões na ocasião do exame de qualificação.

$1 \leq$ Às professoras das disciplinas que cursei na Escola de Enfermagem da USP, pelo envolvimento e ensinamento sensível, o que proporcionou um diferencial nesse estudo.

Aos amigos que construí durante as aulas das disciplinas da pósgraduação, , que me deixam saudades.

1 À Escola de Enfermagem da USP por oferecer a oportunidade de um curso de pós- graduação a profissionais de diferentes áreas e ao Instituto de Psiquiatria do HCFMUSP por possibilitar a realização desse trabalho.

1 Às funcionárias da secretaria pela recepção afável. Em especial à Silvana pela disponibilidade e compreensão em vários momentos.

IL Aos funcionários da informática, pela paciência e disposição em me atender, procurando comigo caminhos para as apresentações.

$1 \leq$ Aos funcionários da cozinha, que muitas vezes me acalentaram com sua comida quentinha.

Aos funcionários da biblioteca, que com presteza e dedicação me atenderam em cada momento.

IL À querida Maria Inês Okai pelo incentivo e por ter me mostrado as possibilidades estatísticas nesse estudo. 
1 À Mariana Loch, do meu coração, pela ajuda tão inesperada quanto caprichada.

Ao prof. João Pedro Farah, que acompanhou cada passo das minhas descobertas e com acolhimento e tolerância ajudou a ampliar minhas percepções por "nossos" gráficos e seus significados para esta dissertação.

1 - Ao prof. Cintra que, como "saído de um livro" (a bem dizer de um DVD), disponibilizou-se em me ajudar.

$1<$ Ao amigo Sergio Nobel por todo apoio, sempre acreditando.

12

Aos pacientes e alunas do consultório pelo encorajamento e compreensão por tantas mudanças nesse trajeto.

Aos amigos e familiares que compreenderam (ou não) minha ausência em muitos momentos durante esse período.

Sei que possivelmente não mencionei todos a quem devo agradecimentos, mas peço humildemente que cada um que se identificar e reconhecer, aceite uma "Estrela de Luz" e saiba perfeitamente que está em meu coração e tem minha disponibilidade e companheirismo para o que der e vier, acreditando que tudo poder ser diferente, melhor e prazeroso.

Quero ainda presenteá-los com a poesia de Carlos Pantoja:

"Borboletas humanas

Voam através da estrada

Trazendo pólen das estrelas

Para os olhos das flores

Que esperam chorando

Lágrimas coloridas

Sobre folhas

De Paz" 
Quem sou?

De onde venho?

Eu sou Antonin Artaud

E basta dizê-lo,

Como sei dizê-lo,

Imediatamente

Vereis o meu corpo atuar

Voar em estilhaços

E em dois mil aspectos notórios

Refazer

Um novo corpo

Onde nunca mais

Podereis

Esquecer-me.

(ARTAUD A, in KEIL, 2004, p.138) 
TESSITORE, Eliana Cappelletti. Os Talentos do Corpo: uma experiência corporal com pacientes com transtorno mental. São Paulo, 2006.

Orientadora: Profa. Dra. Luciana de Almeida Colvero.

\section{RESUMO}

A pesquisa se insere na interface da Fisioterapia e Saúde Mental. Buscou-se descrever e analisar a experiência do "Grupo Corpo" enquanto estratégia de atendimento de abordagem corporal, incluindo técnicas fisioterápicas e dança, face ao processo de reabilitação de pessoas com transtorno mental grave e de longa duração, realizada no Centro de Reabilitação e Hospital Dia (CRHD) do Instituto de Psiquiatria do Hospital das Clinicas da Faculdade de Medicina da Universidade de São Paulo. Os sujeitos dessa pesquisa foram dez pacientes matriculados no Instituto de Psiquiatria do Hospital das Clinicas, pertencentes ao programa de reabilitação do CRHD, participantes do Grupo Corpo durante o ano de 2004 e dez profissionais que atenderam os pacientes nos diferentes grupos do CRHD. Dados sobre o Grupo Corpo foram colhidos a partir registros efetuados pelos terapeutas nos prontuários dos pacientes sujeitos do estudo, após cada sessão do grupo; registros sobre as sensações corporais escritos por cada participante no início e no final da sessão; entrevistas semi-estruturadas realizadas pela pesquisadora com cada um dos pacientes; e, com cada um dos profissionais pertencentes aos diferentes grupos de atendimento dos quais 0 paciente faz parte. Como referenciais teóricos, apresentam-se: a origem e trajetória da fisioterapia ao longo do tempo, como ela configurou seu núcleo profissional, por meio do destaque dos momentos importantes dos seus modos de conceber o corpo, a saúde e a doença e seus modos de intervenção para questionar os modelos fisioterápicos hegemônicos de intervenção no corpo das pessoas focalizando aquelas acometidas de transtornos mentais; a articulação da história da fisioterapia com a história da psiquiatria; as diferentes concepções de abordagem do corpo, da perspectiva de filósofos e de acordo com abordagens não convencionais, como a dança e a música. Os resultados indicam que o Grupo Corpo desenvolveu-se de acordo com necessidades expressas pelos pacientes, prevalecendo a demanda dos pacientes sobre 0 roteiro pretendido. A análise da compreensão dos pacientes sobre o Grupo Corpo foi feita a partir de quatro casos, sob o formato de pequenas histórias que, segundo suas características singulares, representaram as vivências dos pacientes no Grupo Corpo. Essa análise nos mostrou que o Grupo Corpo contribuiu para o desenvolvimento pessoal dos pacientes, com efeitos motores e não motores, que contribuíram para o incremento da contratualidade e exercício de autonomia desses pacientes. Os profissionais entrevistados enfatizaram a necessidade de um trabalho corporal para os pacientes em reabilitação, consideraram que o Grupo Corpo potencializou os trabalhos da equipe, preencheu uma lacuna no Programa de Reabilitação. Discutiu-se o papel de uma "fisioterapia ampliada" e de uma "clinica do inusitado": uma forma de ver e tratar pessoas portadoras de transtorno mental grave e de longa duração, em que "a ênfase não é mais colocada no processo de "cura" mas no projeto de "invenção de saúde" (Rotelli, 1990, p. 30)

Palavras-chave: fisioterapia, saúde mental; expressão corporal. 
Tessitore, E.C. Os Talentos do Corpo: a bodily work experience with mentally disordered patients. [Treatise] São Paulo (SP): Escola de Enfermagem da Universidade de São Paulo; 2006.

\begin{abstract}
The research is inserted in the Physiotherapy and Mental Health interface. It tried to describe and analyze the "Grupo Corpo's experience" as strategy to assist the bodily approach, including physiotherapeutic techniques and dance, facing the process to rehabilitate people with severe and long lasting mental disorder, accomplished at Centro de Reabilitação e Hospital Dia (CRHD) of the Instituto de Psiquiatria do Hospital das Clínicas da Faculdade de Medicina da Universidade de São Paulo. The individuals of this research were ten patients enrolled at Instituto de Psiquiatria do Hospital das Clínicas, belonging to CRHD's rehabilitation program, participants of Grupo Corpo during 2004, and ten professionals who assisted the patients in the different groups from CRHD.Data on Grupo Corpo were collected from records accomplished by therapists in the patients' medical registers, after each show of the group: records on bodily sensations written by each participant at the beginning and at the end of the show; semi-structured interviews accomplished by the researcher with each patient, and with each professional belonging to the different assistance groups of which the patient is part of. As theoretical references: the physiotherapy's origin and path as time goes by; how it has configured its professional core through the distinction of important moments from its manners of conceiving body, health and disease, and its intervention ways to question the hegemonic physiotherapist models of intervention in the people's bodies focusing the ones accessed by mental disorders; the articulation of the physiotherapy history with the psychiatry history; the different conceptions of the body approaching, of the philosophers' perspective and according to unconventional approaches as dance and music. The results reveal that Grupo Corpo has been developed according to the needs expressed by the patients, being prevailed the patients' demand on the intended path. The analysis of the patients' understanding on Grupo Corpo was accomplished based on four cases, presented as brief histories that, according to their unique characteristics, they represent the patients' experiences in the Grupo Corpo. This analysis has shown us that Grupo Corpo has contributed to the patients' personal development, with motor and non-motor effects, which aided to improve the contracture and independence exercise to patients. The professionals who were interviewed emphasized the need of a bodily work to patients during rehabilitation stage, and they considered that Grupo Corpo has empowered the work group, fulfilling the Rehabilitation Program. The role of a "broaden phisiotherapy" and an "untold clinic" was discussed: a way to see and treat people suffering with severe and long lasting mental disorder in which "the emphasis does not focus the "cure" process, but the "health invention" project (Rotelli, 1990,p. 30).
\end{abstract}

Key-words: Physiotherapy, Mental health, Bodily expression. 


\section{SUMÁRIO}

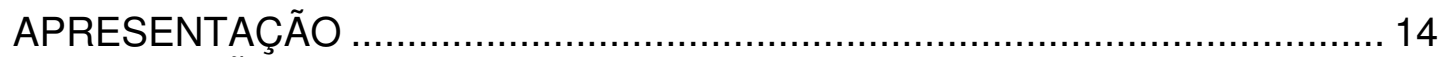

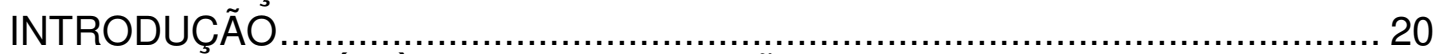

FRANÇOISE MÉZIĖRES: A REVOLUÇÃO NA FORMA DE

TRABALHAR O CORPO ................................................................. 22

A EXPERIÊNCIA DA FISIOTERAPIA NA SAÚDE MENTAL ....................... 29

OBJETIVOS DA PESQUISA ………………………................... 33

ESTRUTURA DA DISSERTAÇÃO ..................................................... 34

CAPÍTULO I: A FISIOTERAPIA E A PSIQUIATRIA - INTERFACES

HISTÓRICAS ............................................................................ 36

1.1 A FISIOTERAPIA E A PSIQUIATRIA DA ANTIGÜIDADE À IDADE

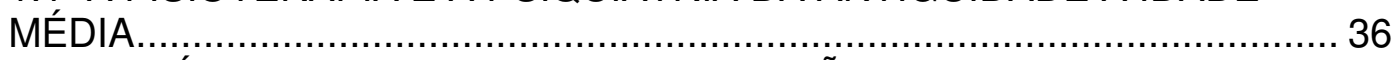

1.2 RENÉ DESCARTES: PAI DA CONCEPÇÃO DA DUALIDADE

CORPO-ESPÍRITO ..................................................................... 37

1.3 A FISIOTERAPIA E A PSIQUIATRIA DA REVOLUÇÃO

INDUSTRIAL AOS TEMPOS ATUAIS ………..................................... 39

CAPITULO II: DE QUE CORPO QUEREMOS FALAR? ……........................ 44

2.1 FRIEDRICH WILHELM NIETZSCHE: CELEBRAÇÃO DA VIDA .............46 46

2.2 DE QUE CLÍNICA QUEREMOS FALAR? ....................................... 48

2.3 A MÚSICA, A DANÇA, O LÚDICO E OS TALENTOS DO CORPO. .......51

CAPÍTULO III: METODOLOGIA ……........................................................5 54

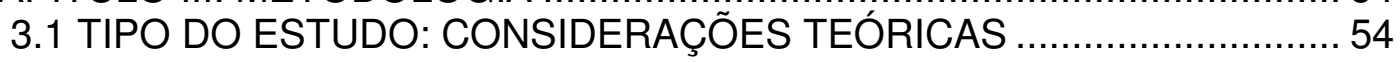

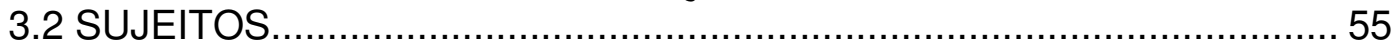

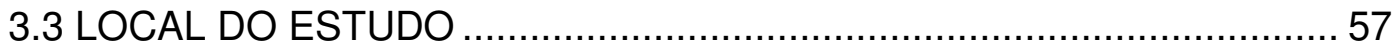

3.4 PROCEDIMENTOS E INSTRUMENTOS DE COLETA DOS DADOS .... 58

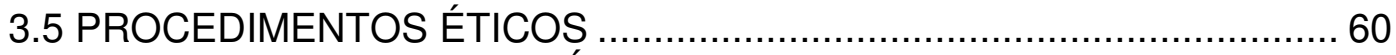

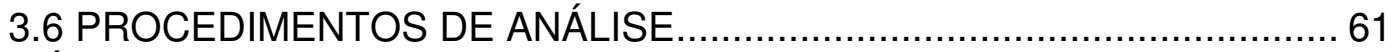

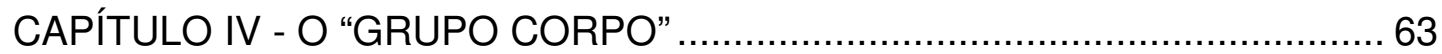

4.1 O "GRUPO CORPO": SUA ORIGEM ………………..................... 63

4.2 O "GRUPO CORPO": SEU FUNCIONAMENTO ……….......................6

CAPÍTULO V: ANÁLISE E DISCUSSÃO DOS RESULTADOS ……………......69

5.1 ANÁLISE DOS DADOS DOS PACIENTES ..........................................69

5.1.1 A história de Ana: uma desorganização comovente .......................69

5.1.2 A história de Lúcia: uma talentosa dançarina sem limites............... 74

5.1.3 A história de Alice: uma flor que desabrochou no "Grupo Corpo" .. 80

5.1.4 A história de João: um paciente marcante para todos do "Grupo Corpo"

5.2 ANÁLISE DAS ENTREVISTAS COM OS PROFISSIONAIS ................... 98

CONSIDERAÇÕES FINAIS ................................................................... 110

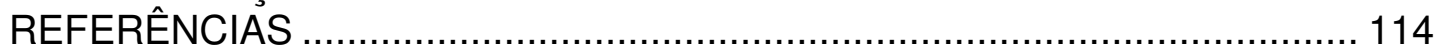

ANEXO I: Termo de consentimento para o paciente ……………………... 122

ANEXO II: Termo de consentimento para o profissional ................................ 124

ANEXO III: Roteiro da entrevista com o paciente .......................................... 126

ANEXO IV: Roteiro da entrevista com o profissional .................................. 127

ANEXO V: Roteiro dos relatórios dos pacientes no inicio e final da sessão ... 128

ANEXO VI: Aprovação do Comitê de Ética................................................... 129

ANEXO VII: Aprovação do Comitê de Ética.................................................. 130 


\section{APRESENTAÇÃO}

A história profissional que me conduz até esta dissertação se inicia com uma formação profissional em fisioterapia. Percorri um caminho diverso do convencional, em busca de uma abordagem do corpo humano considerado não só como arcabouço músculo-esquelético.

Nesta trajetória, experiências com a reabilitação física, e posteriormente com a reabilitação sensorial, me permitiram desenvolver a atuação fisioterápica para pessoas portadoras de acometimentos físicos (neurológicos e/ou ortopédicos) e acometimentos sensoriais (deficiência visual), trabalhando como integrante de uma equipe de reabilitação interdisciplinar. Ao longo dessas experiências de trabalho com ênfase no corpo humano em seu aspecto anátomo-funcional, acabei por encontrar um corpo somático, energético, reflexivo, capaz de pensar e sentir o mundo e de expressar nas posturas e nos gestos a relação mente-corpo e a relação corpo- mundo. Este novo modo de olhar passou a sustentar minha prática fisioterápica.

Entretanto, esta prática suscitou-me uma inquietação: se estava desvelada, pelas posturas e pelos gestos ${ }^{1}$, a existência de uma comunicação entre mente/corpo/mundo, de quais maneiras uma abordagem corporal terapêutica poderia colaborar para uma organização dos estados mental e/ou emocional e assim contribuir para a pessoa se relacionar com sua realidade de vida?

A integração fisio-psíquica parecia-me um referencial básico para atuar como fisioterapeuta junto a pessoas adoecidas ou não. Percebia que havia uma estreita correlação entre determinadas posturas e gestos com determinadas funções psíquicas, qualquer que fosse o contexto de vida das pessoas que acompanhava como fisioterapeuta. Tal constatação instigou a

1 gestos: são a incorporação da expressão e da percepção na da realidade vivida (MACHADO, 1997). 
me aproximar da realidade de pessoas acometidas de um transtorno mental: de que modo uma abordagem corporal terapêutica poderia contribuir?

Foi assim que, em 2003, iniciei minha atuação como fisioterapeuta colaboradora, na equipe interdisciplinar do Centro de Reabilitação e Hospital Dia do Instituto de Psiquiatria do Hospital das Clínicas da Universidade de São Paulo (CRHD/IPq), que atende pessoas portadoras de transtorno mental grave e de longa evolução.

Com a intenção de encontrar uma possibilidade de tratamento fisioterápico para essas pessoas, desenvolvi, numa primeira fase um projeto que pretendia estabelecer protocolos de atendimento, avaliação, tratamento e reavaliações individuais: estratégia fisioterápica científica comumente aplicada em suas diversas áreas de atuação.

Ao adotar essa prática terapêutica deparei-me com algumas dificuldades: os pacientes não mantinham sua freqüência para os atendimentos; outras vezes, não conseguiam colaborar e acompanhar o que estava sendo proposto durante a sessão; ou ainda, não tinham condições de se lembrar das orientações domiciliares recebidas na sessão anterior.

Esses fatores fizeram com que eu repensasse o sentido da estratégia escolhida, qual seja a de seguir protocolos para atendimento fisioterápico individuais, pois não conseguia dar continuidade aos planejamentos, nem tampouco $o$ atendimento individual parecia atender as necessidades dos pacientes naquele momento.

Em busca de uma outra estratégia de atendimento que contemplasse a demanda dos pacientes e considerasse as dificuldades já observadas, passei, numa segunda fase do trabalho, a desenvolver uma experiência de atendimento em grupo juntamente com outro membro da equipe, que foi denominada de "Grupo Corpo".

Realizávamos encontros semanais com os pacientes, desenvolvendo atividades de trabalho corporal, composto por técnicas fisioterápicas e de dança. O "Grupo Corpo", objeto de estudo desta pesquisa, me proporcionou um contato mais próximo e uma melhor compreensão dos pacientes diagnosticados como psicóticos. 
Segundo a Psiquiatria, diferentes são os conceitos sobre as psicoses, não havendo até hoje uma definição de consenso, já que suas definições estão relacionadas aos diversos momentos históricos e vertentes do pensamento psicológico. Em geral, aceita- se que o termo psicose refere-se a disfunções psíquicas cujas causas são orgânicas ${ }^{2}$ ou funcionais ${ }^{3}$ que acarretam uma fragilização do vínculo com a realidade, manifestando-se freqüentemente por delírios, alucinações, comprometimento das funções cognitivas e identidade corporal. Na utilização psiquiátrica mais comum e recente do termo, "psicótico" pode significar também um comprometimento grave do funcionamento social e pessoal, caracterizado por retraimento social e incapacidade para desempenhar as tarefas e papéis habituais (Louza Neto at al; 1995).

Os pacientes participantes do "Grupo Corpo" apresentavam alterações psíquicas que conseqüentemente refletiam-se nos diversos campos de suas vidas. Suas histórias de vida incluíam graves rupturas psicossociais associadas a inúmeros danos nos âmbitos físico, psíquico e social. De modo singular, os pacientes apresentavam diferentes maneiras de se comunicar corporalmente, ora exagerando, ora diminuindo, ora estereotipando sensivelmente suas expressões corporais.

Identificávamos, em alguns pacientes, posturas e gestos que davam a impressão de um estado de isolamento, um corpo que muitas vezes expressava uma falta de presença, como se a pessoa não sentisse seu corpo, não estivesse apropriada dele e nem fosse agente das suas ações, como se a pessoa não se sentisse pertencer ao mundo em que vive ou àquele ambiente. Muitas vezes esta falta de presença no corpo interferia não só em aspectos pessoais, mas também nas relações interpessoais.

2 A psicose orgânica refere-se a uma condição reversível ou não de disfunção mental, que pode ser identificada como um distúrbio da anatomia, fisiologia ou bioquímica do cérebro. (Louza Neto, 1995)

3 A psicose funcional refere-se a uma condição de disfunção mental de origem endógena, identificada como esquizofrenia, uma doença afetiva maior, ou outros distúrbios mentais com características psicóticas. (Louza Neto, 1995) 
Tanto o possível estado de isolamento quanto as expressões corporais exageradas, diminuídas ou estereotipadas, pareciam também estar relacionadas à influência dos mecanismos somáticos de defesa de dor (física e emocional) e de compensações musculares. Geralmente esses mecanismos de defesa fazem modificar o tônus muscular (estado saudável de contração permanente de certas fibras do músculo), ora aumentando-o (hipertonicidade), ora diminuindo-o (hipotonicidade). Essa poderia ser uma das razões da pessoa alterar seus gestos na intenção de suprimir sentimentos de caráter ameaçador, por vezes à custa da produção e manutenção de estados de tensões e algias músculo-esqueléticas, posturas e gestos estereotipados, alterações nos seus sistemas automáticos reguladores, como por exemplo, diminuição da amplitude respiratória decorrente de uma hipercifose dorsal.

As diferentes expressões corporais podiam ser observadas nos encontros, na produção de movimentos exagerados (hipercinesia), diminuídos (hipocinesia), incoordenados, fora de ritmo ou de contexto ao mesmo tempo em que o paciente realizava um discurso incoerente, segundo uma desagregação do seu pensamento (Louza Neto at al; 1995).

Em algumas ocasiões, os pacientes mostravam uma vontade de expressar movimentos mais organizados e, para isso, tentavam relaxar seus músculos, condição para expandir ou conter seus movimentos, sem sucesso na maioria das tentativas. Percebíamos um significativo esforço músculoesquelético para a manutenção desta dinâmica corporal, sustentada pelas expressões coerentes, ou não, com o estado mental, mesmo quando resultava na realização de movimentos exagerados, quanto na realização de movimentos diminutos e rígidos.

Constatávamos também, um significativo esforço do paciente e um gasto de energia, à medida que ele percebia e tentava lidar com seus limites, pretendendo transformá-los, na intenção de "acertar" os exercícios.

O importante naquele momento era o paciente vivenciar e sentir o efeito sobre o corpo dos exercícios que conseguia realizar, e não priorizar a realização biomecânica adequada. 
Após conhecermos melhor os pacientes e a dinâmica de cada um deles, pudemos perceber que o esforço despendido para "acertar os exercícios" nem sempre era empreendido como forma de experimentar, sentir novos movimentos, de realizá-los seguindo a linha do movimento proposto (questão biomecânica) ou ainda de colaborar com a própria evolução, mas tinha o propósito de "dar a resposta certa", ou seja, "falar o que o outro espera que se fale": "fazer o Bingo".

Esta era uma questão sutil e de difícil apreensão que nos obrigava a ficar atentos ao significado de cada tentativa de "acerto". Realizar o que era solicitado só seria desejável para o processo terapêutico se fosse reflexo da experiência corporal. Responder automaticamente ao quê o outro espera que se responda é um modo equivocado de se relacionar ou envolver-se num processo terapêutico. $O$ fato é que isso ocorria independente do paciente estar consciente de sua intenção. $E$ provavelmente nos encontros do Grupo, os pacientes representavam o que Ihes acontecia nos seus cotidianos. Tentar "acertar as respostas", tentar aprovação social constituía um fator presente no modo do paciente se relacionar em sua vida.

Observávamos entre os participantes do Grupo que esses modelos de ação interferiam no fluxo dos movimentos e espontaneidade dos gestos, desviavam a atenção e concentração no próprio corpo e dificultavam a realização das atividades propostas ao grupo.

Também estavam presentes ali, as experiências de vida da pessoa, o que facilitava ou dificultava a movimentação do corpo, assim como a instalação de tensões musculares com tendência à cronificação.

A história de vida também poderia estar colaborando para a existência de alguma dificuldade em movimentar determinadas partes do corpo. A partir de seus depoimentos percebíamos tal possibilidade ao relacionar, por exemplo, uma pequena movimentação dos quadris em função de uma educação muito rígida, ou então, um bloqueio na movimentação do tronco em uma pessoa desprovida de afetos.

A compreensão da dinâmica corporal dos pacientes, seus limites e esforços, nos conduziram às técnicas fisioterápicas e de dança como opção 
de abordagem terapêutica. Tínhamos os objetivos de que os pacientes pudessem alcançar melhores expressões corporais, gastassem menos energia, pudessem aliviar as tensões musculares, ampliassem o modo de se relacionar, encontrassem conforto interno para que pudessem comunicar melhor suas intenções por meio das suas expressões.

Às dificuldades de trabalho corporal acresciam-se dificuldades no lidar com as manifestações do transtorno mental que se exacerbavam no transcorrer do Grupo. Mesmo quando não podiam ser entendidas, atribuíamos um caráter positivo às manifestações do transtorno mental, pois muitas vezes eram as únicas reações que a pessoa conhecia para aquele momento. Portanto, esses eram os modos de se expressar que os pacientes tinham, eram a maneira como conseguiam se estruturar para enfrentar ou suportar aquela situação ou fase de sua vida, de forma consciente ou inconsciente, tínhamos que aceitá-las como uma via de comunicação e de trocas entre os pacientes no seu cotidiano.

Ao longo das experiências permitidas pelo "Grupo Corpo" foram se definindo algumas inquietações/ questões que geraram o tema de estudo do presente trabalho:

- Como seria a percepção deste corpo para quem está acometido por um transtorno mental?

- Como seria o modo de viver dessa pessoa?

Percebi que eu desejava conhecer e entender melhor esses processos, que os pacientes me convidavam a dar início e compartilhar uma jornada para novas possibilidades de conhecimentos e reflexões.

Tudo isto fervilhava em minha cabeça e constituiu a mola propulsora que voltou meu interesse para o mestrado como oportunidade de realizar um estudo que me possibilitasse compreender como a fisioterapia poderia estar inserida no campo da saúde mental e efetivamente intervir e contribuir para a vida melhor a estas pessoas? 


\section{INTRODUÇÃO}

O corpo ensinou-me uma nova altivez - disse Zaratrusta -, que ensino aos homens: não mais enfiar a cabeça na areia das coisas celestes, mas, sim, trazê-la erguida e livre, numa cabeça terrena, que cria o sentido da terra.

(Barrenechea, 2002, p.181).

Até a década de 1960, a fisioterapia era considerada um complemento para tratamentos médicos conservadores e/ou cirúrgicos. Pertencente à medicina física, a prática fisioterápica era vista até então, como uma medida médica (Gonzales Mas, 1965). No Brasil, em 13/10/1969 segundo Conselho Nacional de Saúde, decreto lei 938, a fisioterapia foi reconhecida como curso de nível superior, preparando seus profissionais para prescrever, administrar, avaliar e aplicar eficientemente as diversas técnicas fisioterápicas.

Devido a sua origem e a sua trajetória, a fisioterapia tradicionalmente mantém suas práticas ligadas às experiências nas áreas músculoesquelética (ortopedia, traumatologia, postura, reumatologia, prótese e órtese), neuromuscular (neurologia central e periférica), cardiopulmonar e dermatofuncional (estética, queimados e angiologia) (Delisa, 1992).

Oriunda do saber médico-científico, a fisioterapia tem por objeto o corpo em seu aspecto anátomo-funcional. Por definição, a fisioterapia usa meios físicos para prevenir e tratar as disfunções motoras que acometem o sistema locomotor humano. Desse modo, desenvolve suas estratégias terapêuticas sob uma visão biomecânica do corpo atuando no segmento corporal acometido: a fisioterapia analítica, que trata a parte acometida do corpo para resolver a alteração apresentada.

A visão biomecânica do corpo considera os músculos como elementos mecânicos que definem a ação dos movimentos, atitude que influencia a estrutura do corpo (os ossos) ao mesmo tempo em que a estrutura óssea define a ação muscular (Piret, Bèzieres,1992).

Esta é uma das razões para que muitos dos acometimentos advindos de desequilíbrios mecânicos sejam resolvidos a partir de um trabalho com o 
elemento mecânico, isto quer dizer que por meio de exercícios físicos podem-se aliviar tensões, re-equilibrar posturas e gestos, e conseqüentemente criar um estado de bem estar, ou condições para isto, o que pode repercutir na produção de autonomia do paciente (Bertazzo, 1996).

Apesar dos benefícios referidos, uma questão limitante e importante coloca-se quando os exercícios são repetidos automaticamente pois, além de induzir um automatismo estereotipado (Piret, Bèzieres, 1992), a pessoa imita e repete a imitação. Assim o paciente "realizará movimentos como se estes acontecessem apenas à frente de seus olhos, como se os visse numa tela." (Bertazzo, 1996, p.12).

Esta situação de imitação e repetição mecânica dos exercícios, não facilita nem sequer promove um interesse da pessoa em movimentar seu corpo ou em seu autoconhecimento, além de não colocá-la em contato com a realidade, ao imaginar que seus movimentos acontecem como numa tela, a pessoa pode achar até que eles nem são dela e nem é no seu corpo que eles estão acontecendo.

Para a pessoa acometida de um transtorno mental, essa experiência pode estar associada à sua sugestionabilidade e favorecer o aparecimento da ecopraxia, que é a repetição imitativa do movimento, gesto ou postura de outra pessoa, ou ainda a estereotipia, que é a repetição de um movimento complexo de maneira constante, quase mecânica e desprovida de qualquer finalidade (Louza Neto at al, 1995). Portanto, ao lançar mão da estratégia do paciente repetir os movimentos sugeridos, a fisioterapia corre o risco de colaborar de modo restrito ou ainda não colaborar com esses pacientes.

Além disso, um outro fator é que existimos em um campo gravitacional - temos peso, que carregamos e tentamos equilibrar a todo tempo - que segundo as leis da física, (...) "atua sobre nós de tal forma, que podemos... representar sua ação por um vetor proporcional ao peso do corpo, aplicado ao centro de gravidade deste e dirigido verticalmente de cima para baixo..." (Gaiarsa,1991, p. 23). Como reação fisiológica, reagimos a este peso com um conjunto de contrações musculares, que se opõe exatamente a este peso e em função desta reação, percebemos nosso peso. 
"Nosso peso é sentido por nós sob forma de reação muscular à força da gravidade sobre nossa massa." (Gaiarsa,1991, p. 23).

Esta reação também é influenciada pela posição do nosso corpo no espaço, pois vamos mudando as linhas de movimento, e com elas, muda a maneira como vemos e percebemos o movimento, sua estrutura e sensações. A consciência corporal também se ressignifica, e, com ela, os modos de pensar, sentir e agir, o que nos mostra uma interligação entre a mente e o corpo, portanto uma influência recíproca entre os aspectos biomecânicos e os psicológicos, que podem tornar-se tanto causa como conseqüência de distúrbios não-motores (Gaiarsa,1991).

Ao repetir mecanicamente os movimentos, a força da gravidade continua atuando sobre o corpo, mas pode ser que a pessoa não perceba, não tenha consciência das mudanças que possam estar acontecendo em seus significados. Neste caso, a comunicação entre seu corpo e sua mente está empobrecida ou inexistente pois, ao imitar o exercício, está preocupada em acertá-lo e não em senti-lo em seu corpo. Ao colocar a atenção no corpo abre-se a possibilidade de comunicação entre sua mente e seu corpo, tornando possível vivenciar os movimentos e aí sim ressignificar sua consciência corporal, seus modos de pensar, sentir e agir.

Esta visão ampliada das práticas corporais no campo da fisioterapia tem recebido contribuições teóricas e sido objeto de estudos desde a década de 1940, quando a fisioterapia ganhou a primeira concepção não analítica de tratamento, isto é, "global", de visão e trabalho corporal, que colocou em evidência o conceito do corpo enquanto uma organização músculoesquelético disposta em cadeias musculares: o Método Mézières (Souchard,1998).

FRANÇOISE MÉZIÈRES: A REVOLUÇÃO NA FORMA DE TRABALHAR O CORPO

Françoise Mézières (1909-1991), fisioterapeuta francesa, observou que cada vez que tentava tornar menos acentuada a curva de um seguimento da coluna vertebral, a curva era deslocada para outro 
seguimento. Isso indicava que os músculos não atuavam isoladamente, mas como um todo.

Estabelecia-se o novo conceito de que os músculos funcionavam numa "solidariedade músculo- aponeurótica" - as cadeias musculares - que traria como decorrência, uma nova forma de abordagem do corpo, agora em sua totalidade e abriria a possibilidade de se buscar novas técnicas de cuidado fisioterápico. Desta forma, Mézières proporcionava o bem-estar dos pacientes considerando o corpo em sua totalidade orientada pela busca e tratamento das causas (e não só os sintomas), da integração entre o físico e o emocional (Bertherat, 2001).

Este método serviu de ponto de partida para a criação de várias técnicas corporais com abordagem global de tratamento, que têm como característica considerar a organização músculo-esquelética, disposta em função das cadeias musculares e não mais em função dos músculos isoladamente.

Estas técnicas consideram o individuo como único e indivisível. Para Bertazzo (1996) "Possuímos uma forma que é a soma da herança genética e de atitudes psicocomportamentais" ( Bertazzo, 1996, p.16). Poderiamos dizer que, nossa forma está imersa também na ação do meio ambiente, educação, influências socioculturais, e outros aspectos a serem considerados na busca e tratamento da (s) causa(s) de uma afecção.

Assim, a fisioterapia passou a fundamentar o desenvolvimento de seus trabalhos também nos referenciais holístico ${ }^{4}$ e globalista ${ }^{5}$, que consideram o indivíduo em sua totalidade de ser e viver, compreendendo as inter-relações entre a mente e o corpo. A fisioterapia pôde então, ampliar sua maneira de ver e entender o ser humano e seu corpo, buscando a compreensão do corpo somático e almejando equilíbrio e harmonia para o paciente.

\footnotetext{
${ }^{4}$ Holístico: teoria do universo na qual a natureza viva é vista sob a forma de "todos" em interação e não somente como uma simples soma de partículas elementares, segundo o dicionário Webster's (Souchard, 1996,p.169).

${ }^{5}$ Globalista: “(...) é corrigir simultaneamente” (Souchard, 1996, p. 33).
} 
É importante ainda ressaltar que a nova consideração de que os aspectos mecânico-funcionais resolvem certos desequilíbrios também abrem a possibilidade de consideração da expressão corporal em relação ao outro e ao ambiente. Portanto, o corpo enquanto fluxo não verbal de comunicação traz mensagens, que são construídas também por estes dois aspectos: o mecânico-funcional e o subjetivo.

Estas mensagens, pertencentes ao conteúdo não verbal de comunicação, fazem parte dos estimados $55 \%$ da comunicação humana, não verbal e que se dá por meio de sinais corporais. Mesmo sem a pessoa ter consciência, suas expressões corporais provocam impressões e sensações diferentes em cada pessoa que está ao seu lado, pois dependem de como o espectador a observa, o que torna este aspecto vital nas relações sociais (Silva,1996)

Logo, o corpo, repleto de linguagens internas e externas, fala de diversas maneiras, mediante um sistema de gestos, de mímica, de deslocamentos que utilizamos com vistas a transmitir informações por meio de signos naturais mais ou menos codificados por cada cultura. Assim, configura-se um conjunto de conceitos e de palavras a partir de imagens corporais, sustentando uma determinada forma de ver o mundo (Davis, 1979).

Pode-se pensar que o corpo se organiza durante a ação e por meio dele é que agimos e nos comunicamos. Estas atitudes expressam nossos modos de pensar, sentir, assim como outros aspectos de nossa subjetividade, ambiente, sociedade, política e cultura.

Segundo Louzã Neto (1995), devemos ficar atentos às condições a que a pessoa com transtorno mental está submetida, quais sejam as condições de desorganização mental, comportamental, às peculiaridades de seu discurso e de tumulto emocional. Portanto, as expressões corporais dessa pessoa estarão comunicando fatores importantes do estado em que se encontra.

Embora na literatura recente não tivéssemos obtido estudos específicos sobre sofrimento e expressão corporal em pessoas com 
transtornos mentais, encontramos no antigo estudo de Darwin, The Expression of the Emotions in Man and Animals (Londres, 1872), um dos primeiros ensaios sobre as expressões das emoções (Guiraud, 1980). Darwin observou homens e animais em seu ambiente natural e formulou uma teoria biológica do comportamento gestual que ele considerou hereditário, universal e comum a todas as culturas entre seres da mesma espécie. Tal achado mostra o quanto é antiga esta preocupação e há quanto tempo o homem vê a relação entre as expressões e as emoções.

As emoções e suas formas de expressão estão vinculadas também ao lugar que ocupamos no mundo, visto que é no ambiente social que se organizam as relações. Isso faz com que os seres humanos nunca possam ser compreendidos separados do ambiente em que vivem, isolados do modo como vêem e sentem o mundo, dos valores que atribuem às coisas, às situações, daquilo que acreditam ser verdade. Podemos dizer então que os homens constróem-se o tempo todo um no outro, o corpo e o ambiente, um constrói o outro, ativos o tempo todo.

Curiosamente, na língua japonesa a palavra "(...)pessoa (ningen) é composta de dois caracteres: o primeiro significa "pessoa ou homem", e o segundo 'espaço ou entre'. Este 'entre' (aidagara) significa, no sentido físico uma distância espacial, separando uma coisa em relação à outra. Existir no espaço é o significado primário da existência humana e o 'entre' seria a extensão de um espaço corporificado (shutaitekl)" (Greiner, 2005,p.23).

Logo, se o lugar que a pessoa com transtorno mental ocupa é o da exclusão (pela família ou sociedade, por exemplo), sua tendência será a de retrair-se, seu corpo de recalcar-se, restringindo seus contatos e relacionamentos ou até se isolando.

Portanto, entre a pessoa e o mundo, entre a pessoa e o outro, há um lugar, um espaço físico. É desse lugar que queremos falar: "este 'entre' são os vários relacionamentos da nossa vida e é justamente esta rede de relações que parece prover a humanidade de significados sociais. Ou seja, o homem (...) dificilmente pode ser compreendido sem uma atenção especial às relações que aí se organizam" (Greiner, 2005, p.23) 
Assim, a maneira como nos movemos com o corpo e também na vida, ou a maneira como não nos movemos, pode refletir como nos relacionamos conosco e com o mundo. Estas experiências modificam os modos de pensar, sentir e a partir dessas vivências o corpo muda, se organiza e desorganiza, num movimento contínuo. Estamos falando da pessoa em relação a si mesma e ao mundo, relação que sempre acontece ao mesmo tempo, numa constante influência e ressignificação mútua.

A fisioterapia, enquanto herdeira da concepção médica hegemônica transcorreu um caminho que inicialmente viu o corpo doente como seu objeto, tratando o segmento acometido como uma matéria a ser recuperada, para depois perceber as inter-relações entre a mente, o corpo e o mundo, tendo como alvo a integração da pessoa e a manutenção da harmonia e do equilíbrio com a adoção de uma perspectiva holística e globalista.

Contudo, apesar da ampliação do seu objeto de estudo, a fisioterapia, ao manter a intenção de resolver problemas clínicos, ao objetivar a busca das causas para a supressão dos sintomas, enreda-se na visão racionalista da superação, repetindo a dicotomia: mente $x$ corpo.

Uma das premissas da tradição holística é a oposição em relação à visão racionalista e dicotômica. A tradição holística afirma a importância da integração mente, corpo, dos modos de vida saudável dos indivíduos e sociedades.

Sem questionar a importância das tradições holísticas como um importante referencial para o novo olhar da fisioterapia, abre-se também, com tal olhar, um novo desafio: como evitar o risco do contínuo desejo de mantermos a sensação de um inabalável estado de equilíbrio e harmonia entre o corpo e a mente como sinônimo de saúde, beleza e bem-estar, que sustentam determinados padrões de comportamentos e morfologia corporais, como um clichê da nossa contemporaneidade? Corremos o risco de não entrarmos em contato com a dor, seja ela física ou psíquica, o que pode advir de um "medo de não mais sustentar o plano ou sustentar-se no plano" com conseqüente "desabamento de si": uma possível produção de condição de homogeneização de subjetividades, um específico senso 
comum. Qual o risco de podermos vivenciar a dor, como "um punhadinho de caos, perfurando o compacto muro do senso comum"? (Rolnik,1995,p.67). Como escapar dessa captura da homogeneização?

Escapar da captura da homogeneização pode levar a pessoa a se apropriar de sua singularidade. Rolnik (1995) menciona sobre as outras forças que coexistem ao senso comum. Essas forças vão gerando o que ela denomina de "pólo de decisão" que oscila entre duas linhas de fuga: "vontade de destruição ou vontade de heterogeneização", linhas que vão aparecer no corpo, na voz, como uma mudança de atitude, de entonação da voz, alguma transformação (Rolnik ,1995, p.68 a 70).

Mas, há um preço a pagar por isto. Pode ser o de "não gozar os benefícios sociais como toda pessoa normal", mas o de buscar e percorrer um caminho a partir de estar fiel consigo mesmo, com seus próprios valores: dos valores individuais para uma nova experiência e transformação, "afirmar o ser em sua heterogênese" (Rolnik,1995.p.72 e p.74)

O desejo de não sentir dor ou de se manter em equilíbrio e harmonia como uma alucinação salvadora pode gerar na pessoa, um estado de entorpecimento para a dor, como se estivesse anestesiada para aquela dor ou para os aspectos a ela relacionados. Como se a salvação estivesse na manutenção da condição almejada, linear e permanente de que está tudo bem. Isto não quer dizer que a dor tivesse deixado de existir, ela não desapareceu, e por estar latente, sabe-se que uma hora ou outra essa dor pode reaparecer.

Esta é uma provável reação de fuga da dor para qualquer um, mas para aquela pessoa que porta um transtorno mental, além de poder estar inserida nesta situação, a ela é agregado uma das condições a que está exposta frente ao transtorno mental que é a de que tem sua percepção corporal alterada. A dor dela também não deixa de existir.

Embora a pessoa tenha criado uma estratégia para não sentir dor, esta pode influenciar a morfologia do corpo, suas atitudes, dentre outros aspectos. Bertherat (2002) diz que tentamos sempre fugir da dor e também fazer com que ela não apareça, por esta razão, corremos o risco de 
estarmos suprimindo muitos dos nossos gestos para não sentirmos uma dor, não lembrarmos de um sofrimento ou trauma.

A supressão artificial da dor pode gerar gestos estereotipados, compensações musculares e em decorrência, o aparecimento de outras dores, às vezes em outro lugar do corpo. Pode ser que, aparentemente, o corpo se movimente de forma adequada: o corpo "disfarça" e a performance atinge um patamar de satisfação para a própria pessoa e para os outros, dando a sensação de que ninguém percebe o que está acontecendo e com o tempo leve a pessoa a pensar "sou assim mesmo", "este é meu jeito de ser". Estas impressões podem marcar e se inscreverem na pessoa, o que pode servir de auto-referência para ela e a pessoa passa a se ver a partir desse corpo (Keil, 2004).

Conclui-se, assim, que esta estratégia não parece garantir a resolução do problema. Este modelo, que segue tentativas de enquadramento nos conceitos do que é bom e aceito socioculturalmente, enquanto oriundo de uma extrapolação dos limites de tolerância, pode produzir um outro paradigma: o da possibilidade de mergulhar no conflito, desistir do "efeito anestésico", "entregar-se ao caos e dele extrair uma nova existência" e de dentro da dor, reerguer-se transmutado, e dela sair com uma nova experiência para então, confiar nessa potência com a intenção que ela se manifeste, o que gera confiança e fortalece a "coragem de entrega" (Rolnik, 1995,p.72).

Esta condição também parece refletir-se na morfologia do corpo, visto que a entrega está relacionada à sensação de relaxamento, de flexibilidade, força, reorganização das tensões musculares, confiança no devir e na esperança. Mesmo assim, embora saibamos da possibilidade de sairmos reerguidos, também aqui não há garantia de fato que isto irá acontecer (Rolnik, 1995).

Portanto, pode-se dizer que não há saídas garantidas, ou "não tem uma opção que garanta uma resolução", mas as diferentes opções levantam hipóteses do que pode estar acontecendo com o paciente e apontam possíveis caminhos. Também não concluímos que saúde é estar fora ou 
dentro do senso comum, pois como disse Artaud (Greiner, 2005,p.48) "somos nutridos pela indeterminação da vida em todos os sentidos".

Mesmo assim, parece bem mais interessante correr o risco de nos entregarmos ao caos para a possibilidade de sairmos transmutados e vivermos novas experiências a partir dos nossos conteúdos que podem transitar por diferentes lugares.

Além disso, estamos mergulhados numa existência humana que constata como sua única condição: a da pessoa habitar um corpo vivo e, por este motivo, ocupar um lugar num determinado espaço, pois é esta a sua forma de estar no mundo. Por isso, não podemos compreender o homem separado das suas experiências e ambiente em que vive, nem isolado das relações que ali se estabelecem, pois constróem o tempo todo um no outro o corpo e o ambiente, um constrói o outro, ativos o tempo todo.

É nesse campo de interinfluência que ocorre a fusão da subjetividade individual com outra subjetividade. Este é o espaço onde as subjetividades se fundem formando os territórios da intersubjetividade. Isto não quer dizer nem bom nem ruim, pois está "para além do bem e do mal", como postula Nietszche (Keil, 2004, p.147).

Estas possibilidades nos instigam a busca de uma outra maneira de ver estas questões frente às raízes da tradição fisioterápica. Deste modo, quando a fisioterapia pode ir além do olhar positivista e entende que "o sintoma não é apenas doença, antes a face de uma verdade que destroça o sujeito e que precisa encontrar expressão" (Keil, 2004,p.29) lança seu lugar, como possibilidade terapêutica para a pessoa com transtorno mental.

\section{A EXPERIÊNCIA DA FISIOTERAPIA NA SAÚDE MENTAL}

A experiência do "Grupo Corpo" junto aos portadores de transtorno mental possibilitou-nos identificar aspectos muito interessantes da prática da fisioterapia. Com a intenção de conhecer as intervenções fisioterápicas já existentes na área da Saúde Mental foi realizada uma revisão bibliográfica.

Após o levantamento nas bases de dados, para identificar trabalhos com estes tipos de intervenção, encontraram-se escassas publicações na 
literatura brasileira sobre estes tipos de intervenção. Dentre elas, destacamse as publicações do fisioterapeuta brasileiro Juarez P. Furtado.

Num de seus artigos "A Fisioterapia na Saúde Mental" (1995), discorre sobre três experiências de trabalhos representativos de abordagem corporal em psiquiatria sumarizadas a seguir.

O fisioterapeuta francês Sivadon partiu da observação de que, apesar de muitos esquizofrênicos crônicos não conseguirem realizar trabalhos ou expressarem-se verbalmente, eram capazes de se expressarem corporalmente. Isto inspirou a publicação de artigos e de seu livro "La rééducation corporelle des funtions mentales" (1969), que teve por objetivo recriar os elos inter-humanos. Esta abordagem se caracterizou, inicialmente, por contato corporal direto entre monitor e paciente, em seguida passando à ginástica individual, já sem o contato direto corporal com o fisioterapeuta, mas ligado por meio de objetos intermediários, evoluindo para atividades em grupo, em que usou educação física, esportes e trabalhos de expressão gestual (Furtado, 1995).

No Programa de Terapia Psicomotora, H. Van Coppenolle e cols fisioterapeutas distinguiram formas de tratamento para os diferentes grupos de pacientes (depressivos não psicóticos, anoréxicos, nervosos, esquizofrênicos) internados em hospital psiquiátrico. Para os esquizofrênicos usaram jogos e competições como estímulos de criatividade e sociabilidade. Para a avaliação psicomotora adotaram a escala de LOFOPT, que avalia as relações afetivas, atividade ou passividade, controle de movimentos, descontração, atenção, expressividade, confiança em si mesmo, comunicação verbal, e capacidade de submeter-se a regras (Furtado, 1995).

Outro trabalho citado por Furtado (1995) foi o de Castro, fisioterapeuta brasileira que desenvolveu um trabalho com um grupo de pacientes psiquiátricos, usuários de um Centro de Atenção Psicossocial (CAPS). Inicialmente, avaliou os usuários quanto ao desejo de conhecerem e de se aproximarem do próprio corpo, por meio da criação e improvisação de movimentos. Para o tratamento usou jogos, massagem, relaxamento, 
toque, dança, passeios e reflexões. Este trabalho teve o objetivo do resgate da autonomia dos pacientes.

Apesar de não mencionar os resultados de cada uma destas experiências, conclui que "as técnicas de abordagem corporal têm muito a contribuir nos cuidados em saúde mental" e salienta que a fisioterapia deve ocupar seu lugar dentro das novas perspectivas nos cuidados em Saúde Mental ( Furtado,1995, p.22)

Segundo o mesmo autor, esta participação só se efetivará como processo frente à construção de uma nova e importante forma de atuação. $\mathrm{E}$, para isso, as intervenções deverão "ter como suporte um novo paradigma que considere as inter-relações entre corpo e mente, visto que seriam insustentáveis numa concepção mecanicista e ortodoxa do corpo" (Furtado, 1995, p. 22 ).

Munhoz e cols (1991), fisioterapeutas, descrevem a experiência que desenvolveram atendimentos em hospital psiquiátrico. Os pacientes participaram de terapias corporais, para que pudessem expressar suas emoções e saíssem da apatia. A melhora dos pacientes foi sentida pela equipe terapêutica do hospital que passou a encaminhar os pacientes precisamente para este trabalho. Em decorrência das terapias, foi observada uma melhora emocional e de comportamento de vários pacientes, fazendo da fisioterapia uma somatória terapêutica na psiquiatria.

Marinho (1988) relata o desenvolvimento de um projeto de atendimento fisioterápico a pessoas usuárias do Serviço de Atenção Integral à Saúde Mental (SAISM). O trabalho teve origem na percepção do medo, solidão, desconfiança, ansiedade e da repercussão de tais sentimentos no corpo com tensões musculares, falta de gestualidade, rigidez de movimentos e alteração do sono. Além do trabalho corporal visando minimizar estas repercussões, os fisioterapeutas responsáveis pelo projeto promoveram a socialização dos pacientes por meio de atendimentos em grupo.

No levantamento da literatura internacional existente nas bases de dados consultadas, não foram encontradas publicações específicas da área 
da fisioterapia em saúde mental, apenas trabalhos que relacionam os exercícios físicos à saúde mental.

Veale (1987) publicou o artigo "Exercicies and mental health", em que revisa as alterações de humor provocadas pelos exercícios, e seu potencial no tratamento e prevenção de desordens mentais. Para isto estuda os efeitos imediatos de mudanças de humor frente a realização de exercícios aeróbicos, anaeróbicos, corridas, levantamento de pesos, exercícios para flexibilidade, coordenação e relaxamento, a partir de distúrbios metabólicos cerebrais pertinentes a determinados comprometimentos mentais, como no caso da depressão. Observa que os exercícios promovem a melhora da raiva e hostilidade, diminuição dos mecanismos de defesa dentre outros. Discute os benefícios dos exercícios quando realizados segundo um programa regular, autodisciplina do paciente em realizá-los ao ser acompanhado por um fisioterapeuta para a realização correta dos movimentos e sobre a importância dos tratamentos adjuntos necessários, como os neurolépticos por exemplo. Ao final, Veale sugere a realização futura de pesquisas nesse campo através de outras experiências clinicas com a realização de exercícios.

Adams (1995), em seu artigo "How exercise can help people with mental health problems.", descreve os ganhos psicofísicos que obteve um jovem com o diagnóstico de esquizofrenia crônica, ao ter participado de um programa de 12 semanas de exercícios físicos progressivos. Para observar qualquer mudança no estado do paciente usou uma escala classificatória. Adams relata que foram significantes as trocas dos funcionamentos psicológicos, comunicação, interesse pessoal e melhora do estado ânimo, motivação e percepções de imagem corporal. Seu nível de bem estar físico aumentou, mostrando menor retardo motor e tensão muscular.

Nas referências bibliográficas internacionais citadas por estes dois autores encontram-se várias publicações que também relataram os benefícios físicos e psicológicos na realização de exercícios, para prevenção e tratamento de desordens mentais, como por exemplo Sachs (1981) que usou corrida como forma terapêutica para pessoas com depressão; Hesso 
(1982) que relatou sua experiência com atividade física para esses pacientes; Martinsen (1989) que lançou mão dos exercícios aeróbicos para pessoas com esquizofrenia.

Houve, assim um predomínio de utilização de exercícios aeróbicos e fitness, que têm como referência a abordagem mecanicista ${ }^{6}$. Por outro lado, a revisão bibliográfica também revela que, a partir das experiências concretas dos fisioterapeutas com pacientes com transtornos mentais ocorreu uma evolução da atuação fisioterápica. De práticas convencionais, com ênfase em técnicas de analgesia muscular e exercícios biomecânicos para o alivio de dores e/ou tensões musculares, passou-se para a busca de estratégias terapêuticas que passaram a envolver dança, passeio com os pacientes, por exemplo, com o objetivo de alcançar o "encontro do paciente com seu próprio corpo", o alívio de dores, o relaxamento e a sociabilização.

\section{OBJETIVOS DA PESQUISA}

Diante do exposto, neste estudo buscamos descrever e analisar a experiência do "Grupo Corpo" enquanto estratégia de atendimento de abordagem corporal, incluindo técnicas fisioterápicas e dança, face ao processo de reabilitação de pessoas com transtorno mental grave e de longa duração. Para tanto, foram estabelecidos os objetivos específicos a seguir:

1. Compreender o significado atribuído à experiência de participar do "Grupo Corpo" pelos portadores de transtorno mental usuários de CRHD.

2. Compreender o significado do "Grupo Corpo" para o projeto de reabilitação dos usuários, na perspectiva dos trabalhadores da equipe interdisciplinar.

\footnotetext{
"Mecanicista: referente a "mecanicismo" que, nas origens da ciência moderna, com Galileu (1564-1642), Newton (1642-1727) e Descartes (1596-1650), refere-se à doutrina que considera todos os fenômenos naturais passíveis de quantificação e geometrização, em decorrência de sua organização em leis universais de causalidade mecânica ( dicionário Houaiss, 2001).
} 


\section{ESTRUTURA DA DISSERTAÇÃO}

Para iniciar esta jornada, numa primeira etapa, busquei 're-conhecer' a origem e trajetória da fisioterapia ao longo do tempo, como ela configurou seu núcleo profissional, por meio do destaque dos momentos importantes dos seus modos de conceber o corpo, a saúde e a doença e seus modos de intervenção para questionar os modelos fisioterápicos hegemônicos de intervenção no corpo das pessoas focalizando aquelas acometidas de transtornos mentais. Foi o que apresentei nesta introdução.

Em seguida, detive-me na articulação da história da fisioterapia com a história da psiquiatria. Resultou dessa busca o primeiro capítulo da dissertação "A Fisioterapia e a Psiquiatria - Interfaces Históricas".

No segundo capítulo, ainda no âmbito teórico, procuro apresentar diferentes concepções de abordagem do corpo, da perspectiva de filósofos e de acordo com abordagens não convencionais, como a dança e a musicoterapia, completando o mosaico de referenciais presentes na idealização do "Grupo Corpo", na sua condução e que indicaram os caminhos da coleta, análise e discussão dos dados de avaliação colhidos.

No terceiro capítulo há a contextualização da metodologia adotada para concretizar uma coleta de informações e opiniões junto aos usuários participantes do "Grupo Corpo" e aos profissionais da equipe de cuidados a estas pessoas.

O quarto capítulo foi dedicado a descrever o "Grupo Corpo" e os acontecimentos gerados nessa experiência que me levaram a propor uma maneira diferente de intervir junto a essas pessoas, inspirados na direção de um novo olhar para o núcleo profissional da fisioterapia para, em seguida.

No quinto capítulo apresento a análise e discussão dos resultados a partir de quatro casos, sob o formato de pequenas histórias que, segundo suas características singulares, representaram as vivências dos pacientes no "Grupo Corpo", e a partir dos depoimentos colhidos juntos aos profissionais do programa de reabilitação do CRHD.

Nas Considerações Finais discuto o papel de uma "fisioterapia ampliada" e de uma "clinica do inusitado": uma forma de ver e tratar pessoas 
portadoras de transtorno mental grave e de longa duração, em que "a ênfase não é mais colocada no processo de "cura" mas no projeto de "invenção de saúde" (Rotelli, 1990, p. 30). 


\title{
Capítulo I: A FISIOTERAPIA E A PSIQUIATRIA - INTERFACES HISTÓRICAS
}

\author{
1.1 A FISIOTERAPIA E A PSIQUIATRIA DA ANTIGÜIDADE À IDADE \\ MÉDIA
}

Saber da origem da fisioterapia nos remete à antiguidade. Aproximadamente 4000 a.C., os "médicos" da época já tinham a preocupação de eliminar as doenças e a dor por meio de técnicas e procedimentos com o uso de agentes físicos: choques de peixes elétricos em banhos de imersão; água e argila quente sobre áreas afetadas, além do uso de óleos, ervas medicinais e aromáticas para massagens e inalações. Tais intervenções podem ser consideradas precursoras das diversas técnicas fisioterápicas da atualidade como, por exemplo, a hidroterapia, a termoterapia e a massoterapia (Shestack, 1987).

Segundo o autor citado, antes da era cristã, especialmente na Grécia e China também eram usados movimentos corporais específicos e planificados para vários tratamentos de acometimentos e deformidades do aparelho locomotor e respiratório. Galeno se utilizou de ginástica planificada para corrigir o tórax deformado de um rapaz. Há relato de exercícios para evitar obstruções de órgãos, como os intestinos, por exemplo (Linderman, 1970; Shestack, 1987).

Na antigüidade, o "louco" circulava livremente e gozava de liberdade. A loucura vista como inerente à condição humana, não era considerada doença, portanto não existia necessidade de cura. (Foucault, 1995). Entretanto, já começava, nessa mesma época, a despontar o entendimento da loucura como doença. Hipócrates (460-377 a.C.), denominado o "pai da medicina", considerava a loucura uma desordem da natureza orgânica e corporal do homem e sua causa como algum desequilíbrio do estado físico. Hipócrates reconhecia o cérebro como o principal órgão do corpo humano; para ele a temperatura e umidade poderiam afetar o cérebro e causar a 
loucura; ele acreditava que os pensamentos saudáveis seriam decorrentes do equilíbrio dos homens (Selesnick, 1980).

Durante a Idade Média européia, período obscurantista e decadente, situadas entre a Antiguidade e o Renascimento (século $\mathrm{V}$ ao XV), muitas das "doenças do corpo" e a loucura, foram consideradas como uma possessão dos maus espíritos, algo a ser exorcizado, expulso do corpo do doente para curá-lo. Nesse período, os "tratamentos" eram submetidos às condições de controle da igreja, que considerava o espírito soberano e olhava o corpo e a condição humana como algo impeditivo às questões da alma. Este corpo, onde habitava a alma, não podia mais ser visto por dentro, sob pena de sacrilégio, crença eclesiástica que contribuiu para a interrupção/não avanço dos estudos na área da saúde (Selesnick, 1987)

A preocupação com o corpo saudável reapareceu no Renascimento (século $\mathrm{XV}$ ao $\mathrm{XVI}$ ), expresso no humanismo e nas artes. Este período foi marcado pelo grande avanço dos estudos anatômicos além do aparecimento de outras especialidades na área da saúde, visto a atenção dada tanto ao corpo lesado quanto à manutenção do corpo são e a possibilidade de ver o corpo por dentro (Selesnick, 1987). No inicio do Renascimento, o louco era considerado como alguém que possuía sua razão própria, ou seja, os loucos "não eram mais considerados possuídos pelo demônio, mas como pessoas perigosas ou improdutivas" (Oliveira, 2000 p. 33).

Cabe destacar que neste período, denominado pré-capitalista (do século XVI ao XVIII), a aptidão e inaptidão natas ainda não eram um critério para definir normal e anormal, respeitando-se o tempo e o ritmo psíquico do trabalhador (Resende, 1987).

\subsection{RENÉ DESCARTES: PAI DA CONCEPÇÃO DA DUALIDADE CORPO- ESPÍRITO}

René Descartes (1596 a 1650), filósofo e matemático francês, rompeu os preceitos da ciência oficial da época com suas idéias. Em um de seus primeiros escritos, em favor da condição humana do livre pensar como condição de existência chega ao dito: "Penso, logo existo" (Silva, 1999). 
Por um lado, com este conceito "Penso, logo existo", esse autor chega à conclusão que a primeira condição humana está relacionada ao Eu e que sua condição de existência é conseqüência da capacidade lógica do pensamento (Silva, 1999). Por outro lado, também pré destina aqueles que não conseguem ter bom senso nem raciocínio correto, à condição de inexistência, como os loucos, por exemplo.

Descartes tinha consigo uma grande inquietação interior: buscava incessantemente a consolidação de um método que, partindo da dúvida absoluta, do simples, pudesse chegar à complexidade com a mais absoluta certeza. O que ele mais queria era conseguir um modo de chegar a verdades concretas e nunca aceitar qualquer coisa como verdade se essa coisa não pudesse ser vista clara e distintamente como tal (Silva, 1999).

Outro aspecto importante da filosofia de Descartes é sua concepção do homem numa dualidade corpo-espírito. O universo consiste de duas diferentes substâncias: a mente ou substância pensante, e a matéria sendo basicamente quantitativa e teoricamente explicável em leis científicas e fórmulas matemáticas. Só no homem as duas substâncias se juntariam em uma união substancial, unidas, porém delimitadas, e assim Descartes inaugura um dualismo radical.

$\mathrm{Na}$ quinta parte de um de seus famosos escritos "Discurso do Método", esse grande filósofo fez uma descrição fisiológica, em que o corpo humano é uma "máquina de terra", construído por Deus, e suas funções dependem das funções dos órgãos, que desempenham seus papéis tal qual uma máquina de um relógio. Acredita que a alma está ligada ao corpo por uma glândula cerebral (Pineal), onde ocorre a interação entre espírito e matéria.

$\mathrm{Na}$ teoria mecanicista de Descartes, o corpo sendo uma máquina, deve entregar o controle das suas ações para a alma. Portanto, dentro desta lógica racionalista, o corpo é efetivamente cindido da mente, rompendo com o raciocínio mágico-religioso. Este corpo passa a ser medido como uma máquina orgânica para produzir trabalho, o louco como aquele que não 
produz e está fora da razão, está na condição da desrazão, da exclusão (Silva, 1999).

Esses conceitos sustentaram os valores sociais e econômicos dominantes no capitalismo, período marcado pela Revolução Industrial (século XVIII), que fortaleceram a capacidade produtiva da pessoa como critério fundamental de normalidade e de direitos, enquanto todos os nãoprodutivos eram segregados. Considerados uma subespécie eram colocados à margem da sociedade, incluindo os acometidos por transtornos mentais (Resende, 1987),

As concepções de saúde e doença associadas a um corpo saudável somente tangenciaram a psiquiatria nascente na época. Segundo Oliveira (2000), sem muito contribuir, pois o que se conta desta época, são os maus tratos na assistência ao louco, que eram tratados somente por intervenções no corpo, ora contido, ora torturado ou abandonado, visto que era no corpo que a loucura estava implantada.

Neste momento é importante ressaltar que os preceitos "cartesianos" inauguraram a abordagem da teoria científica que usamos até hoje, além de subsidiarem muitos métodos de tratamentos atuais e formas de ver 0 mundo. Se, por um lado, esses conceitos consideram somente aquilo que é lógico e mensurável, por outro lado não consideram a pessoa em sua singularidade, nem tampouco contemplam o olhar qualitativo, como valores existentes e fundamentais para outras compreensões.

\subsection{A FISIOTERAPIA E A PSIQUIATRIA DA REVOLUÇÃO INDUSTRIAL AOS TEMPOS ATUAIS}

Voltando à busca dos momentos fisioterápicos históricos interessantes, encontra-se entre 1779 e 1849, o nascimento da cinesioterapia (terapia através do movimento) como uma atividade precursora da fisioterapia, concebida por Don Francisco y Ondeano Amorós, que não era médico. Estes movimentos tinham a finalidade de manutenção de uma saúde forte, tratamento de enfermidades, reeducação de convalescentes e correção de deformidades. A cinesioterapia teve uma 
significativa expansão com a Revolução Industrial (séculos XVIII e XIX), visto as extensas jornadas de trabalho. Essa realidade deu origem também aos princípios da ergonomia, que segundo a literatura, ainda não estava caracterizada enquanto uma prática reabilitadora (Shestack, 1987).

O final do século XVIII, com as idéias do lluminismo, os princípios da Revolução Francesa e a Declaração de Direitos do Homem dos Estados Unidos, representaram um grande marco na história da psiquiatria. Foram protagonistas destas transformações: Pinel na França; Tuke, na Inglaterra; Chiaruggi, na Itália; e Todd, nos Estados Unidos da América. Transformações estas que instituíram a loucura enquanto doença, objeto da medicina, segundo a realização da classificação e descrição dos sintomas de várias psicoses e outros acometimentos psiquiátricos, cujo princípio terapêutico residia no isolamento do louco nos grandes asilos - o tratamento moral - baseado na consideração que a alienação mental era provocada por causas físicas e morais (Resende, 1987; Oliveira, 2000).

Ao mesmo tempo em que os alienados ganhavam condições de tratamento mais humanas, parecia ser esta a maneira de buscar a garantia para a manutenção da purificação e tranqüilidade social (Silva, 1999).

Seguindo a lógica da manutenção da tranqüilidade de determinada comunidade é que foi constituída a Medicina Social (séc. XIX), voltada para o controle do meio social e da coletividade, fazendo parte de uma tecnologia disciplinar e normativa, surgida em um determinado momento histórico como dispositivo regulador biopolítico com o objetivo de gerir a vida social por um projeto de normalização e de controle social dos corpos, reorganização das relações familiares: intervenção-regulação para a produção de indivíduos física e moralmente adequados, adestrados e disciplinados com vistas à docilização e aumento da produtividade (Braga, 2000), valores que sustentaram as práticas de saúde por longo tempo.

Esse era um dos panoramas do século XIX, época em que também surgia Sigmund Freud (1856 a 1939), médico austríaco, neurologista que criou uma técnica verbal de tratamento para aqueles acometidos de traumas e conflitos. Notou que esses acometimentos estavam expressos em atitudes, 
método que denominou "Psicanálise" (Docine, 2000), o que permitiu um outro modo de atenção aos loucos, por buscar um caminho de tratamento que não o corporal, como teria sido até então.

O Brasil, no início do século $X X$, quando se seguiam as propostas européias de tratamento, passou a usar novas práticas terapêuticas como as colônias agrícolas, técnicas de tratamento pelos choques, choques insulínicos, choques cardiazólicos, eletroconvulsoterapias e lobotomias. (Braga, 2000).

$\mathrm{Na}$ seqüência do processo histórico e social da humanidade, a fisioterapia e a psiquiatria tiveram um grande desenvolvimento no período denominado de Pós-Guerra (século XX) segundo tentativas de reforma, humanização, recuperação das funções terapêuticas (Amarante,1995). O avanço resultou da aplicação de princípios de reabilitação por meio de práticas recuperadoras de seqüelas físicas e mentais frente à demanda dos soldados egressos das batalhas, portadores de seqüelas e de disfunções do sistema locomotor.

Estes princípios abarcaram as ações de saúde em geral, em função das necessidades sócio-econômicas dos países envolvidos, empenhados em recuperar os ex-soldados com vistas à reinseri-los na sociedade como seres produtivos. Era preciso não sobrecarregar financeiramente os governos com pessoas "inválidas". Esta lógica orientou o tratamento tanto de pessoas com seqüelas físicas quanto mentais.

Os tratamentos seguiram esta lógica: tanto a fisioterapia quanto a psiquiatria almejaram alcançar a "produção" de corpos adequados para o retorno à sociedade produtiva: o pensar e agir sobre a doença no âmbito coletivo. A categoria trabalho/não trabalho passou a ser elemento de distinção entre o normal e patológico (Braga, 2000).

Olhar para a história do corpo na saúde e na saúde mental, sob a ótica da evolução da assistência tanto em seus aspectos culturais quanto éticos e sócio-políticos, reporta a um modelo de atenção que reflete uma situação crônica de abandono e descaso. Esse modelo determinou uma longa jornada de confinamento dos doentes mentais, segregando-os em 
suas residências, nos asilos, presídios, casas de misericórdia, hospícios, manicômios e hospitais, pois perante a uma situação de "não saber o que fazer como controlar e onde colocar o louco" a sociedade tomou atitudes de exclusão.

Essas concepções agregadas à pressão industrial da época, mecanismos de repressão, violência/docilização, além do desconhecimento dos efeitos dos tratamentos, sustentaram o uso indiscriminado dos recursos terapêuticos comumente adotados (ex. eletrochoque, psicocirurgia) e dos psicofármacos, que estavam sendo desenvolvidos na década de 1950. (Barros, Egry, 2001). Nesse momento surge no Brasil a psiquiatria privada que colaborou para o grande aumento das internações, o que reforçou as práticas de exclusão e controle, resultando no que se chamou de industrialização da loucura (Amarante, 1995).

Paralelamente a essa situação, a fisioterapia, a partir de suas práticas reabilitadoras e tratamentos segmentares buscou um novo entendimento da pessoa, saindo da visão coletiva para considerar a pessoa como única e indivisível inserindo um olhar holístico, o que colaborou para a criação de técnicas globais de tratamento (Bertherat, 2001).

$\mathrm{Na}$ década de 1960 surgem as primeiras idéias de desinstitucionalização, resultando na desmontagem dos manicômios proposta por Basaglia, psiquiatra italiano, que inaugurou a Psiquiatria Democrática Italiana, que preconiza a idéia de que a sociedade deve buscar novos caminhos para incluir a pessoa com transtorno mental entendendo que a loucura, ou "desrazão", é parte da natureza humana (Amarante,1995). Estes preceitos influenciaram a reforma da assistência psiquiátrica brasileira que ocorreu a partir da década de 1970, que propôs a extinção progressiva dos manicômios e sua substituição por outros recursos assistenciais, que na década de 1980, resultaram em São Paulo, nos Caps (Centro de Atenção Psicossocial) e em Santos os Naps (Núcleo de Atenção Psicossocial), para compor uma rede de atenção à saúde mental, vinculada à comunidade (Silva, Barros, Oliveira, 2002). Nesse contexto, em 1996 é inaugurado o CRHD/IPq/HCFMUSP (Centro de Reabilitação e Hospital Dia do Instituto de 
Psiquiatria do Hospital das Clinicas da Faculdade de Medicina da Universidade de São Paulo).

Atualmente observa-se que, concomitantemente à existência de recursos assistenciais substitutivos, encontram-se práticas sustentadas ainda no modelo hospitalocêntrico , o que permite a discussão no campo teórico-conceitual sobre a desconstrução do modelo hospitalocêntrico, e consequentemente a construção de redes substitutivas de assistência em saúde mental (Rezende, 1987), em que a atuação da fisioterapia possa estar inserida.

Nesse percurso histórico procurou-se evidenciar pontos de convergência entre a trajetória da psiquiatria e da fisioterapia, visto que ambas foram geradas no processo de produção do conhecimento humano e que, apesar das suas particularidades, foram marcadas pela hegemonia de um saber de bases biológicas e racionais acerca da saúde e da doença humana. 


\section{Capitulo II: DE QUE CORPO QUEREMOS FALAR?}

(...) o corpo é o lugar de toda travessia na aventura humana. (Keil, 2004, p.9)

Embora alguns autores considerem que o corpo há muito foi esquecido, não podemos dizê-lo com tanta convicção ao considerarmos que o corpo foi uma constante na história da cultura, tratado e visto segundo diferentes concepções e contextos filosóficos, antropológicos, político, etc. Como toda história, a do corpo e do seu cuidado, também não foi seqüencial, pois como processo dinâmico, o passado "modificando-o e lançando projeções futuras" (Greiner, 2005,p.16), trouxe ao corpo diversos modos de descrevê-lo, entendê-lo e tratá-lo.

O corpo que queremos falar é o corpo pós-moderno, contemporâneo, situado no Ocidente. Corpo que abarca e imprime as transformações de uma transição social, parte da realidade atual. Ao mesmo tempo em que é reflexivo da própria subjetividade e condição decorrente de seus acometimentos, expressa um mundo onde há um bombardeio maciço e aleatório de informações que não se constituem como um todo.

Segundo Esper (2004) a realidade é fragmentada em retalhos, composta por vivências parciais, porque não há uma crença na totalidade a totalidade contemporânea é plural e salienta esse aspecto, quando enfatiza que a sociedade pós-moderna se caracteriza por um individualismo hedonista e personalizado.

O ambiente pós-moderno é povoado pela cibernética, pela robótica industrial, pela biologia molecular, pela medicina nuclear num mundo traduzido por imagens e signos, cuja principal característica é ser regido pela informação, processada em "bits". A velocidade com que o avanço da técnociência se estabelece desenha uma nova cartografia contemporânea comandada pela transitoriedade e efemeridade que num ritmo vertiginoso, faz com que o status das verdades seja sempre provisório, produzindo insegurança e desamparo. 
Essas mudanças aceleradas podem afetar a capacidade de decisão e adaptabilidade, ser fonte de angústia, ansiedade, frustração e outros transtornos, pois a experiência prévia, que faz parte do capital psíquico no enfrentamento das situações, passa a ter uma consistência frágil em virtude de ter que estar sempre reconfigurada, falhando na atuação de ancoragem psíquica.

A velocidade alucinante da instauração do "novo" como uma necessidade (produzida pela mídia), acaba impedindo a instalação e aprofundamento de emoções, relacionamentos mais profundos $\mathrm{e}$ duradouros, criando a cultura do descartável e conseqüentemente levando o sujeito a um crescente individualismo, alienação de si mesmo e de seus próprios desejos, onde o laço social fica fragilizado e a pessoa corre o risco de se ver quase que desprovida de subjetividade (Esper, 2004).

Desse modo, observamos que o corpo recebe o excesso da sobrecarga psíquica que acaba repercutindo e sendo expresso no que se poderia chamar de um corpo contemporâneo.

Podemos pensar então, que a nossa cultura e sociedade atuais não favorecem aspectos integrativos, o que pode dificultar muitas faces da vida de quem porta transtorno mental, inclusive reforçando as condições de isolamento, alienação e desmotivação.

Muitos dos nossos pacientes, também estão sujeitos a desfocar sua condição de existência corpórea ao voltarem sua atenção à problemática diretamente advinda de seu acometimento mental. Envoltos nessas questões torna-se comum considerarem que a existência corpórea não é natural para si mesmo, e sim, exclusividade para aqueles profissionalmente envolvidos com atividades físicas, como os atletas, dançarinos, atores, ou para os acometidos de um transtorno físico.

Por outro lado, muitos dos envolvidos com seu corpo físico, usam-no indiscriminadamente, sem dar-se conta dos seus limites, usando-o como máquina. 
O fato é que não vivemos fora de um corpo vivo, portanto somos corpo. Ao pensarmos qual face desse corpo queremos falar, encontramos 0 olhar de Nietzsche.

\subsection{FRIEDRICH WILHELM NIETZSCHE: CELEBRAÇÃO DA VIDA}

Friedrich Wilhelm Nietzsche (1844-1900) nasceu na Prússia, enquanto grande pensador da cultura e artista influenciou a filosofia posterior, como em Deleuze, Heidegger e Foucault. Fez a crítica da modernidade. Por muitos considerado um dos precursores da pós modernidade, desbravou os horizontes possíveis com o artifício da linguagem, e não cedeu diante das adversidades, em sua vida incomum. Influenciou também os existencialistas e os psicólogos. Além de músico, poeta filólogo e filósofo foi um grande e profundo escritor. (Braga, 2005)

Nietzsche afirmou que a interpretação científica não era única, que a razão considerada como divina levava a um falso bem estar e era um reflexo diminuído de algo transcendente. Tinha as convicções como cárceres, como inimigas mais perigosas da verdade do que as mentiras. Procurou denunciar todas as formas de renúncia da existência e da vontade (Barrenechea, 2002).

Para ele, divino era o homem, que libertava seu espírito toda vez que realizava o longo processo de abandono de hábitos e comodidades e acreditava que "todos os valores têm um fundamento corporal e terrestre, eles afirmam o corpo e a terra", portanto o homem é corpo, pois é no corpo que se conjuga um momento, num eterno devir: o corpo é um "fio condutor interpretativo", um "fio guia", que segura e efetivamente nos conduz através de movimento e transformação, assim desfaz a culpa e auto punição milenar, vendo o corpo como inocente, sadio e criador (Barrenechea, 2002,p.181).

Para Nietzsche é o nosso corpo que determinam os processos psíquicos e todas as possibilidades de sentir, agir e pensar para compreendermos a realidade. Coloca a rejeição corporal como oriunda das 
doenças corporais, onde os doentes e moribundos se vêem com medo da finitude da própria existência (Barrenechea,2002).

Nietzche considera todos os órgãos internos, a alegria, o prazer e todas as questões do corpo como um milagre, e assim, fontes de vida plena: a ética da afirmação, da celebração, da alegria, o corpo redescoberto, reconstruído. Afirma a própria dor como condição sutil de "forma de criação": a dor como meio de transcendência e superação dos limites, diferente da dor (visão de Platão e Sócrates), como meio de "meditação para a morte" (Barrenechea, 2002, p.181,182).

Diz ainda que tanto o homem como o mundo são fluxo, força, jogo e movimento. Nietzsche celebra o corpo, afirma a beleza e alegria da vida, dizendo que somos encarnados, efêmeros, finitos, porem não culpados, prisioneiros ou reféns de uma mácula ancestral (Barrenechea, 2002).

Este conceito móvel, de pluralidade de forças, que perpassam incessantemente o homem e o mundo, que compõem cada momento vivido, nos leva além das idéias racionalistas, inserindo o homem numa historia individual e coletiva, impregnada de conceitos, ancestrais e ultra modernos, por vezes contraditórios, que compõem a pós-modernidade, no seu contexto de globalização.

A questão é que pensarmos o corpo e a clínica desta maneira nos coloca numa situação instável e vulnerável, no sentido de que, ao deixarmos para trás o que nos é familiar e, portanto nos dava segurança: a lógica racionalista/positivista podemos estar indo ao encontro da lógica que se caracteriza como movediça (Maffesoli, 2005, p.7).

Michel Maffesoli, sociólogo francês que dirige o Centro de Estudos do Atual e Quotidiano (CEAQ), diz que a "lógica movediça" por si só é composta de movimento e também, porque ao lidarmos com algo novo nos colocamos instáveis e inseguros. Define que esta é uma lógica da atração, das afinidades, dos afetos e processos emocionais, que, constituída na sua maior parte do não-lógico, espontaneamente se exprime através das artes, esportes, consumo, rebeliões e explosões sociais (Maffesoli, 2005, p.7). 
Para explicar isso considera que deve-se entender, estética no seu sentido mais simples: vibrar em comum, sentir em uníssono,experimentar coletivamente tudo o que permite a cada um, movido pelo ideal comunitário, de sentir-se daqui e em casa neste mundo. Assim o laço social é dominado cada vez mais pelos afetos, constituído por um estranho e vigoroso sentimento de pertença (Maffesolil, 2005, p. 8)

Se pensarmos assim, os pacientes estão transpassados pelas coisas do mundo, onde co-habitam diversos valores, permeados pela globalização, pela mídia e ao mesmo tempo pela busca daquilo com que se identificam.

Esta é uma lógica que pode propor uma clinica voltada para uma percepção diferenciada do paciente, considerando que tanto ele quanto o terapeuta estão sujeitos às múltiplas forças dos corpos e do mundo. Esta estratégia de atendimento escuta, considera e acolhe 0 inusitado,poderíamos chamá-la de "clinica do inusitado", pois nela também está representado aquilo que é.

\subsection{DE QUE CLÍNICA QUEREMOS FALAR?}

Neste contexto, podemos considerar, tal como Saraceno (1996), que "reabilitação não é questão de tecnologia... é uma estratégia". Não faz sentido passar um paciente, de um estado de "desabilidade" a um estado de "habilidade", de um estado de incapacidade a um estado de capacidade visto que "não necessitamos de esquizofrênicos pintores, necessitamos de esquizofrênicos cidadãos... que exerçam sua cidadania" (Saraceno, 1996, p.14 e 16).

O mesmo autor objetivando o aumento da participação na sociedade e a desconstrução da cronicidade, salienta a importância da reconstrução da contratualidade, a realização de trocas sociais, que pode passar por vários caminhos, como o da arte, por exemplo. Fala da contratualidade que se dá

\footnotetext{
${ }^{7}$ Desabilidade (Disability). Tradução do termo de origem inglesa usado em psiquiatria para caracterizar a perda de possibilidades de sobrevida decorrentes da doença ou da iatrogenia dos tratamentos.
} 
tanto em casa quanto no trabalho quanto na rede social, lugares onde estão inseridos todos os atores do processo de saúde - doença: os profissionais, os usuários, os seus familiares e toda comunidade (Saraceno, 1996).

Saracceno coloca ainda que, os profissionais também têm capacidades e incapacidades, o que os faz não serem capazes completamente e nem ao contrário. Cada um com seu poder e exercício de contratualidade na sua vida pessoal e profissional e que ao gerarmos o conteúdo do conceito da palavra reabilitação, corremos o risco de sermos portadores de uma técnica específica por exemplo, se "sou terapeuta ocupacional, sou capaz de fazer carpintaria com os psicótico" (Saraceno,1996, p.14), se sou fisioterapeuta sou capaz de aplicar a técnica neuromuscular denominada "Bobath" no paciente.

Estes modos de atendimento não alcançam, ou alcançam pobremente o paciente. São aqueles que mesmo atualizados em suas técnicas específicas, despertencem a pessoa a ser tratada, de sua subjetividade, muitas vezes isolando-a do contexto em que vive e dos seus desejos, até mesmo o de ser tratada ou não. Eu chamaria este modo de atender de: "atendimento tecnologicamente automatizado".

Portanto, necessitamos de terapeutas cidadãos ao pretendermos colaborar para o exercício da cidadania do paciente. Se esta passa a ser uma condição básica para qualquer formação terapêutica a que possamos estar estimulados a realizar, torna-se uma possível estratégia de atendimento .

Podemos considerar que este é um momento de busca de novos modos de olhar a pessoa com transtorno mental, a loucura e, sobretudo de descobrir melhores atitudes, tanto políticas quanto clínicas, para o tratamento psiquiátrico. Aí a fisioterapia se insere como parte de uma nova tendência terapêutica mundial referente ao tratamento à pessoa portadora de transtorno mental.

Enquanto nova tendência terapêutica podemos pensar numa estratégia fisioterápica, com vistas a colaborar para a autonomia destes pacientes, segundo o pensamento da reforma psiquiátrica brasileira. 
Assim, podemos entender a autonomia como a capacidade de um individuo gerar normas, ordens para a sua vida, frente as situações que necessite/queira enfrentar.

A idéia de autonomia, segundo Kinoshita (1996) está em que "somos mais autônomos quanto mais dependentes de tantas mais coisas pudermos ser, pois isto amplia as nossas possibilidades de estabelecer novas normas, novos ordenamentos de vida" (Kinoshita, 1996, p.57).

Isto quer dizer que, quanto mais eu me relaciono e quanto mais eu posso depender das coisas, maior minha condição de autonomia. Se posso contar com o apoio de pessoas, ou da equipe que me trata, em meus projetos e/ou em minhas dificuldades, mais condições tenho para estabelecer novos ordenamentos em minha vida.

Portanto, autonomia não vem a ser questão de ter habilidades, ou de auto-suficiência, bem ao contrário, é na relação de dependência que o grau de autonomia se apóia: se dependo se "posso contar com... posso confiar em". Esta confiança fortalece, no outro e em si mesmo, a coragem de entrega (Rolnik,1995, p.72). Poderíamos dizer que, este ciclo alimenta a autoconfiança, a confiança na vida, na possibilidade de vir-a-ser e na capacidade de realizar mais coisas e ter melhores condições para rever normas, jeitos de viver, de olhar a vida e assim a vida pode ganhar amplitude.

Trata-se, pois de trabalho terapêutico, voltado para a reconstituição das pessoas, enquanto pessoas que sofrem como sujeito. Talvez não se "resolva" por hora, não se "cure" agora, mas, no entanto seguramente "se cuida"... que significa ocupar-se, aqui e agora, de fazer com que se transformem os modos de viver e de sentir o sofrimento do "paciente" e que ao mesmo tempo, transforme sua vida concreta e cotidiana, que alimenta este sofrimento (Rotelli, 1990, p.33).

Acreditamos que precisamos nos sentir acolhidos, identificados, pertencidos a nós mesmos, a nossa realidade de vida, para que tudo ou qualquer coisa que façamos tenha sentido. Observamos ainda que, quando 
isto ocorre, estamos "enganchados", ganhamos sentido, nossas sensações se avivam e nossas percepções mudam.

Ao optarmos por uma estratégia de atendimento em que a questão deixa de ser a supressão dos sintomas, para dirigir-se ao desvelamento, acolhimento e transformação dos sujeitos, a fisioterapia atravessa o olhar cartesiano (problema-solução), rumo a uma nova lente: a da construção e descontrução de crenças, valores e relações de contato com a realidade, através de uma estratégia móvel de tomada de consciência e ressignificação das expressões corporais.

\subsection{A MÚSICA, A DANÇA, O LÚDICO E OS TALENTOS DO CORPO.}

Os achados literários nos contam que a música e a dança parecem ter sido oriundos da mesma época, intenção humana e divina. Ambos nasceram na pré-história, pertencentes a cerimônias religiosas, como manifestação dos temores, afetos, iras e recusas. Tanto uma quanto outra passou por conjuro mágico, rito, celebração popular e diversão. Há ainda a hipótese de que a música teria nascido da dança a partir dos movimentos rítmicos do corpo humano (Ossona,1988).

Interligadas por natureza são importantes elos de conexão entre as atividades internas do homem e o mundo à sua volta. Enquanto formas artísticas de comunicação, modificam-se esteticamente de cultura para cultura. " Amplas vias de expressão parecem, a música e a dança, estarem enraizadas nas camadas mais profundas de nossa personalidade, onde percepções sensoriais, sentimentos e pensamentos se integram" (Langslet, 1991, p.11-12).

Sabemos que o ser humano percebe os sons desde a fase intrauterina e observamos que a partir dos primeiros anos de vida os sons são percebidos diretamente pelo corpo. Portanto, música e movimento são inseparáveis. A estimulação por meio dos dois, melhora a consciência corporal, percepção sinestésica, mantém atenção e concentração (Bang, 1991). 
"Na maioria das vezes, a música aumenta nosso bem estar, capacitanos a relaxar, estimula o pensamento e a reflexão, proporciona consolo e nos acalma, ou nos torna mais energizados, nos leva a sair do lugar e ir à luta" (Langslet,1991, p.11-12). Observamos os mesmos efeitos em relação à dança.

Tornam-se terapêuticas ao circunscreverem-se enquanto atividades organizadas com a intenção de expandir o desenvolvimento e cura durante 0 tratamento, a educação e reabilitação de pessoas com psicose, distúrbios emocionais, dentre outros acometimentos (Langslet, 1991)

Frohne (1991), em seu capitulo intitulado: "Musicoterapia a Educação Social e na Psiquiatria", fala que a música enquanto terapia teria a função de preparar e aprofundar o trabalho terapêutico orientado para o conflito. E que a musica pode ser utilizada com a finalidade de apoiar, estimular, ajudar a desenvolver a orientação espacial e temporal, os sentimentos e a conscientização do próprio corpo e das próprias sensações. Associada a movimentos corporais, pode ainda ser utilizada para favorecer potencialidades correspondentes ao estado de desenvolvimento do Eu. Essas atividades agregadas, têm a função de estruturar e reduzir a ansiedade, desenvolver a sensibilidade, a expressão, a experimentação da fantasia, a assimilação de normas satisfatórias e a rejeição de normas negativas, materiais reprimidos, impulsos, áreas dissociadas da personalidade, ajuda a diferenciar a percepção do corpo e seus limites, desenvolver a capacidade do paciente de pleitear um lugar nesse mundo e lidar com a proximidade e distância (Frohne,1991).

Neste contexto, este trabalho busca colaborar para uma fisioterapia ampliada e desinstitucionalizada mediante um projeto de abordagem corporal em grupo, através do uso de técnicas fisioterápicas e de dança, visando contribuir para uma organização físico-mental-emocional de pessoas portadoras de transtorno mental crônico grave e que estão em processo de reabilitação.

Este tipo de fisioterapia vai além da intervenção no campo cinéticofuncional, pois agrega o objetivo de através de um trabalho corporal, 
colaborar para o alcance da emancipação deste paciente. Para isto, não se pode olhar o paciente "despertencido" de sua história e realidade de vida, como um corpo sem identidade nem sofrimento, como uma pessoa limitada, desorganizada, sem desejos ou talentos.

Portanto, não é o caso de suprimir os sintomas, mas de trazer à luz seu conteúdo, acolhendo-o, para a possibilidade de lidar com eles e transformá-los. Do mesmo modo, desvelar outros conteúdos que a pessoa tem preservados, ampliando o exercício e o uso deles: os seus talentos, pois é nesse corpo que tudo isto está representado. 


\section{Capítulo III: METODOLOGIA}

(...) Somente na teoria se pode dizer que a ciência é a interpretação verdadeira da realidade, porque na prática, toda a interpretação realiza apenas uma versão historicamente possível (Demo, 1981, p. 25).

\subsection{TIPO DO ESTUDO: CONSIDERAÇÕES TEÓRICAS}

Para alcançarmos os objetivos deste estudo utilizamos a pesquisa qualitativa, visto ser essa compreensão "(...) um movimento totalizador que reúne a condição original, o movimento significativo do presente e a intencionalidade em direção do projeto futuro." Esse método incorpora tanto os significados quanto as intencionalidades presentes nas atitudes das pessoas e nas relações sócio-culturais, econômicas-políticas e ideológicas . Vistos enquanto processos, são considerados tanto nos modos como se constituem quanto nos seus movimentos de transformação, como importantes construções humanas (Minayo,1993,p.252).

Minayo (1993) esclarece que a abordagem qualitativa é uma metodologia que está relacionada ao saber teórico e prático. Fala que esse método é muito utilizado no campo da saúde, visto a complexidade dessa realidade tanto no campo teórico como no prático, que abrange estratégias e visão multidisciplinar, o que demanda conhecimentos distintos integrados e que coloca de forma imediata o problema da intervenção (Minayo, 1993, p. 253).

Saber dos possíveis efeitos da experiência do "Grupo Corpo" junto aos pacientes e aos profissionais da equipe de reabilitação, nos inspira a um estudo do "Grupo Corpo", como uma "(...) unidade dentro de um sistema mais amplo. $O$ interesse, portanto, incide naquilo que ele tem de único, de particular, mesmo que posteriormente venham a ficar evidentes certas semelhanças com outros casos ou situações. Quando queremos estudar algo singular, que tenha um valor em si mesmo, devemos escolher o estudo de caso" (Ludke, André,1986, p. 17). 
O Estudo de Caso, como ainda afirma Triviños (1987, p. 133) "É uma categoria de pesquisa cujo objetivo é uma unidade que se analisa profundamente", onde estará inserido o "Grupo Corpo" como o caso a ser estudado enquanto experiência de atendimento ao portador de transtorno mental enquanto atividade que integra o trabalho da equipe do CRHD.

Deste modo, o "Grupo Corpo", repleto de singularidades, é permeado e permeia os outros grupos, pois uma das características da equipe de reabilitação multidisciplinar, é que os grupos de atendimento têm suas próprias lentes como ponto de partida, tornando-os únicos ao mesmo tempo que significam e resignificam seus trabalhos por serem comunicantes entre si. Isto explica tanto as particularidades quanto a suposta semelhança entre os grupos e confirma o pressuposto de que "(...) para uma apreensão melhor do objeto, é preciso levar em conta o contexto em que ele se situa" (Ludke, André,1986, p.18). Portanto para melhor apreender o "Grupo Corpo", é preciso considerar a equipe que ele faz parte.

O desenvolvimento deste estudo percorre três fases, quer sejam: a primeira aberta ou exploratória, a segunda mais sistemática em termos de coleta de dados e a terceira consistindo na análise e interpretação sistemática dos dados e na elaboração do relatório (Ludke, André, 1986).

Nestes estudos as investigações com indivíduos e grupos favorecem o aprofundamento da descrição de determinada realidade. Os resultados obtidos permitirão o teste e a construção de hipóteses analíticas que revelarão relações ou explicações sobre o objeto estudado mediante 0 diálogo com as bases teóricas escolhidas (Vasconcelos, 2004).

\subsection{SUJEITOS}

Os sujeitos dessa pesquisa foram dez pacientes $(7$ mulheres e 3 homens) matriculados no Instituto de Psiquiatria do Hospital das Clinicas, pertencentes ao programa de reabilitação do CRHD, participantes do "Grupo Corpo" durante $\mathrm{O}$ ano de 2004 e os dez profissionais que atenderam os pacientes nos diferentes grupos do CRHD. 
Durante o ano de 2004 participaram do "Grupo Corpo" dezenove pacientes. Dentre eles, dez colaboraram com a pesquisa. Estes pacientes são adultos, com idade média (no ano de 2004) de 34 anos, solteiros, sendo sete mulheres e três homens, dos quais três deles com nível universitário completo, três com segundo grau completo, três com primeiro grau completo, um deles com primeiro grau incompleto. Apresentaram condições diversas tanto nos aspectos sócio-culturais e econômicos, e são portadores de transtorno mental grave e de longa evolução (nove deles com algum tipo de esquizofrenia e um deles com Transtorno Obsessivo Compulsivo), com quadros cinético-funcionais em diferentes graus de alterações e importante comprometimento psicossocial. Dos nove pacientes que não participaram da pesquisa, um deles relatou não ter vontade de realizar a entrevista, o outro relatou que estava ocupado em estudar para prestar um concurso além de estar cuidando da casa e dos filhos. Outro deles estava internado, frente ao agravo de seu acometimento, segundo contato realizado com familiar. Os outros seis pacientes não conseguiram ser localizados.

Para analisarmos as possíveis contribuições do "Grupo Corpo" nos diferentes grupos de atendimento que cada paciente se insere, participaram também dessa pesquisa os dez profissionais que atenderam os pacientes nos diferentes grupos. Realizou a entrevista a totalidade de profissionais da equipe.

Os profissionais envolvidos foram cinco mulheres e cinco homens adultos de diversas faixas etárias, dois deles com formação em auxiliar de enfermagem, três médicos, uma terapeuta ocupacional, uma psicóloga, uma enfermeira, um educador físico e uma assistente social. Todos eles constituem a equipe "fixa" (funcionários do Hospital das Clinicas), atuantes diretos em um ou mais grupos de atendimento.

Para a participação foi considerado o desejo de colaboração e disponibilidade para entrevista por parte de cada sujeito. 


\subsection{LOCAL DO ESTUDO}

O presente estudo foi realizado no Centro de Reabilitação e Hospital Dia (CRHD) do Instituto de Psiquiatria do Hospital das Clinicas da Faculdade de Medicina da Universidade de São Paulo.

O CRHD, desde sua inauguração em 1996, tem suas instalações físicas no $4^{\circ}$ andar do prédio do Instituto de Psiquiatria. Composto por uma equipe interprofissional, formada por psiquiatras, psicólogos, assistentes sociais, enfermeiros e auxiliares de enfermagem, educador físico, auxiliar administrativo; colaboradores formada por fisioterapeuta e massoterapeutas, além de estagiários, aprimorandos e residentes.

Esta equipe desenvolve seus trabalhos voltados para o atendimento a portadores de transtornos mentais graves e de longa duração através de duas modalidades de atendimento; quer sejam: a de Hospital Dia com capacidade para trinta usuários e a de Reabilitação Psicossocial com capacidade para vinte usuários.

O Hospital-Dia (HD) funciona em regime de internação parcial de segunda a sexta feira das 8:00 às 16:00 horas. Os pacientes são encaminhados para o CRHD pelas enfermarias, ambulatório e pelo setor de psicoterapia do Instituto de Psiquiatria.

O programa de Reabilitação, ao qual o "Grupo Corpo" está inserido, visa colaborar para o desenvolvimento da autonomia e exercício de cidadania dos pacientes objetivando sua reinserção social.

A equipe interdisciplinar se reúne semanalmente para a discussão dos casos e indicações terapêuticas, que seguem com seus planos de tratamento multidirecionais e flexíveis, segundo a evolução clínica e demanda do paciente.

Os atendimentos dos usuários desenvolvem-se predominantemente em grupo, com a participação de todos os profissionais da equipe. Destacamos que o ajuste e acompanhamento medicamentoso são realizados pelo médico em atendimentos individuais. 
Segue a relação geral dos grupos de atendimento:

1. Grupo de Atividades

2. Grupo de Atividade Externa

3. Grupo de Atividade Física

4. Grupo de Cidadania

5. Grupo de Conscientização

6. Grupo de Convivência

7. Grupo de Desenho e Pintura

8. Grupo de Família

9. Grupo de Lazer

10. Grupo de Literatura

11. Grupo de Psicodrama

12. Grupo de Psicodrama com Familiares

13. Grupo de Psicoterapia

14. Grupo de Reorientação Ocupacional

15. Grupo de Terapia Ocupacional

16. Grupo Tocar (massoterapia)

17. Grupo de Vídeo

18. Oficinas Terapêuticas

19. "Grupo Corpo"

\subsection{PROCEDIMENTOS E INSTRUMENTOS DE COLETA DOS DADOS}

Por entendermos a complexidade e diversidade de fonte de dados, os dados para a compreensão do "Grupo Corpo" foram obtidos por meio de:

1. registros efetuados pelos terapeutas nos prontuários dos pacientes sujeitos do estudo, após cada sessão do grupo (registro das condutas terapêuticas adotadas, participação e desenvolvimento do paciente no Grupo);

2. registros sobre as sensações corporais escritos por cada participante no início e no final da sessão conforme etapa número 1 e 4 das sessões do grupo a serem citados abaixo . (AnexoV); 
3. entrevista semi-estruturada realizada pela pesquisadora com cada um dos pacientes que participaram do "Grupo Corpo" durante o ano de 2004 . (Anexo III)

4. entrevista semi-estruturada realizada pela pesquisadora, com cada um dos profissionais pertencentes aos diferentes grupos de atendimento dos quais o paciente faz parte (Anexo IV).

Foi escolhida a entrevista semi-estruturada, pois "(...) parte de certos questionamentos básicos, apoiados em teorias e hipóteses, que interessam à pesquisa, e que, em seguida oferecem amplo campo e interrogativas, fruto de novas hipóteses que vão surgindo à medida que se recebem as respostas do informante. Dessa maneira, o informante, seguindo espontaneamente a linha de seu pensamento e de suas experiências dentro do foco principal colocado pelo investigador, começa a participar na elaboração do conteúdo da pesquisa." (Triviños, 1987, p.146)

Foram realizadas ao todo vinte entrevistas, conduzidas pelo pesquisador em dias e horários pré-agendados das quais dezoito delas em sala privada localizada no próprio CRHD. Um dos pacientes solicitou que a entrevista fosse realizada em sua casa, e outro deles no consultório da fisioterapeuta.

As entrevistas foram gravadas e após as gravações, foram transcritas e realizadas as anotações pessoais após cada entrevista, que colaboraram para o melhor entendimento do discurso.

O convite feito aos usuários e profissionais para participarem da pesquisa foi prontamente aceito por todos. Entretanto, alguns profissionais fizeram considerações que chamaram nossa atenção para o fato de que um estudo, retrospectivo, estaria muito distante temporalmente o que poderia dificultar lembranças sobre o que havia acontecido no "Grupo Corpo" naquela época. Também referiram que os pacientes poderiam ter dificuldades em lembrar do Grupo em função de possível déficit de memória associado aos acometimentos a que estão sujeitos. Houve ainda questionamento quanto à validade de fazer as entrevistas, demandando 
tempo e dedicação para um trabalho científico que provavelmente traria poucos dados produtivos.

Após uma reflexão cuidadosa de tais questões, o pesquisador decidiu manter os procedimentos de coleta de dados previstos. Manteve-se a proposta de realizar as entrevistas, pois só por meio delas se poderia, de fato, saber se as pessoas se lembrariam, quais lembranças teriam resistido ao tempo e, sobretudo, criar uma oportunidade para melhor compreender o significado do "Grupo Corpo" como parte do projeto de reabilitação do CRHD para os pacientes e para a equipe.

Iniciamos as entrevistas com os pacientes e, curiosamente, todos com que conseguimos contato lembravam do "Grupo Corpo", assim como do ano de 2004, que foi marcado pela dança e o uso do esqueleto como referência para o trabalho corporal.

O período em que os pacientes estiveram participando do "Grupo Corpo" foi variável (sete meses em média). O tempo transcorrido entre a participação no "Grupo Corpo" de 2004 e o momento da entrevista também foi variável.

As entrevistas mostraram que essas variações não influenciaram as lembranças. Todos se lembraram de vários aspectos, segundo as facilidades e esforços de cada um. Alguns deles chegaram a se lembrar imediatamente do nome dos participantes, dos profissionais. A maioria relatou as diferentes etapas das sessões, de como se sentiam naquela época e, sobretudo, atribuíram às atividades realizadas importantes significados, como veremos a seguir.

\subsection{PROCEDIMENTOS ÉTICOS}

O convite para a participação na pesquisa foi realizado verbalmente e o consentimento por parte do entrevistado foi registrado através de Termo de Consentimento Livre e Esclarecido, devidamente assinado pelo pesquisador e por cada sujeito da pesquisa segundo a concordância e aceitação de cada um, segundo os Anexos I e || cujo teor está em conformidade com o que preconiza a Resolução nำ196/96 que trata das 
Diretrizes Éticas e Normas Regulamentadoras de Pesquisa em Seres Humanos.

Para garantir sigilo e privacidade para os entrevistados desse trabalho, todas as entrevistas foram realizadas em lugares resguardados onde cada participante pôde se sentir confortável em responder as questões ao entrevistador. $O$ total sigilo das entrevistas foi garantido ao entrevistado mediante o Termo de Consentimento Livre e Esclarecido como já foi dito acima, foi lido e assinado por cada participante e entrevistador. Foi também assegurado ao entrevistado o direito inequívoco de acesso a todo e qualquer dado de sua própria entrevista, além do direito a veto de qualquer parte ou suspensão da utilização de sua entrevista. Os nomes verdadeiros dos entrevistados serão substituídos por nomes fictícios no decorrer deste trabalho, tomando-se o máximo de cuidado para se evitar toda e qualquer possibilidade de identificação.

Este trabalho também teve a autorização por escrito do Comitê de Ética do Hospital das Clinicas (Anexo VI) e da Escola de Enfermagem da USP (AnexoVII), que autorizaram por escrito a utilização dos dados colhidos para efeito da realização da pesquisa .

\subsection{PROCEDIMENTOS DE ANÁLISE}

Com intenção de conhecer o que havia acontecido no "Grupo Corpo" no período de 2004, inicialmente realizei um levantamento dos dados registrados nos prontuários e relatórios que os pacientes escreviam. A partir deles encontrei informações como caracterização pessoal, freqüência nas sessões, participação, preferências por determinadas atividades, relação das atividades realizadas, dentre outros. Como um modo de trazer à luz possíveis aspectos de interesse para o conhecimento do que havia acontecido naquele período, encontrei auxílio nos procedimentos estatísticos, visto ser um conjunto de técnicas destinadas a descrever e resumir os dados, a fim de que possamos tirar conclusões a respeito de características de interesse (Magalhães, 2005). Dentre os resultados obtidos 
escolhi apresentar no capitulo seguinte, um dos gráficos que julguei mais significativos.

Muito embora os recursos estatísticos utilizados tivessem trazido à luz um panorama do que aconteceu no ano de 2004, necessitamos usar do método de análise qualitativa para compreender de forma abrangente e sistematizada a experiência do "Grupo Corpo". Pois é a pesquisa qualitativa propícia para observar, descrever, comparar e analisar as características do atributo, tema e as dimensões subjecentes a um fato ocorrido ou uma experiência vivida (Silva, Trentini, 2002).

Considerando a complexidade do objeto estudado, para aprofundar a análise do significado do "Grupo Corpo" para os pacientes, selecionei quatro casos em torno dos quais fiz uma análise e discussão inter-relacionando-os com os dados de outros pacientes, com os referenciais teóricos, e com os registros da coordenadora do grupo/pesquisadora nos prontuários dos pacientes, dos dados contidos nos relatórios que os pacientes preenchiam no início e final da sessão e das entrevistas realizadas com os pacientes.

Com relação à análise das entrevistas com os profissionais para a compreensão do significado do "Grupo Corpo" para o projeto de reabilitação do CRHD, procurei identificar, a partir das respostas das entrevistas, temas relevantes que responderam ao objetivo proposto: origem do "Grupo Corpo" e seu lugar de importância; benefícios específicos do "Grupo Corpo" para os pacientes, sugestões quanto à articulação/integração do "Grupo Corpo" com os demais grupos, o desejo de integração entre os grupos em geral, valorização do trabalho do "Grupo Corpo". 


\section{Capítulo IV - O "GRUPO CORPO"}

\subsection{O "GRUPO CORPO": SUA ORIGEM}

O "Grupo Corpo" originou-se do Grupo de Dança do CRHD que no transcorrer de sua experiência contemplou a complexidade da abordagem corporal do paciente psicótico, sentindo a necessidade de agregar ao aspecto lúdico das técnicas de dança utilizadas, a especificidade do trabalho fisioterápico. Por esta razão o Grupo de Dança deu seu lugar a um novo grupo terapêutico pertencente à equipe do CRHD: o "Grupo Corpo".

Desse modo o "Grupo Corpo" surgiu em 2003 como uma das modalidades de intervenção da equipe interdisciplinar do Centro de Reabilitação e Hospital Dia do Instituto de Psiquiatria do Hospital das Clínicas da Universidade de São Paulo (CRHD/IPq), junto aos seus pacientes, portadores de transtorno mental grave e de longa evolução, à qual me integrei como fisioterapeuta. A concepção do trabalho foi baseada nas perspectivas teóricas citadas neste estudo, com objetivo de proporcionar aos pacientes a experiência de conhecer e vivenciar seu corpo. Entendia-se o corpo como meio pelo qual o indivíduo se relaciona, pensa e age: uma ponte entre o indivíduo e o mundo externo.

Desde então, o "Grupo Corpo" passou a constituir-se um espaço terapêutico de trabalho corporal e de dança, um lugar para o paciente manifestar suas inquietações, dores, confortos e desconfortos com o corpo: um lugar de escuta para a expressão do corpo e desta maneira contribuir para a construção do próprio indivíduo.

\subsection{O "GRUPO CORPO": SEU FUNCIONAMENTO.}

A indicação dos pacientes para o "Grupo Corpo" é realizada a partir da reunião da equipe interdisciplinar do CRHD. O "Grupo Corpo" acompanha o paciente durante o percurso de seu tratamento no CRHD. 
Este Grupo terapêutico tem como algumas de suas características ser flexível, aberto, não ter limite mínimo ou máximo de participantes e receber constantemente novas participações de pacientes.

Embora o "Grupo Corpo" continue ativo, definiu-se para este estudo o período das sessões realizadas de 16/01/04 à 10/12/04, fase em que demos início a um tratamento norteado por um roteiro de atendimento que percorreu os diversos segmentos corporais e suas correlações. A programação das atividades foi também integrada à demanda do grupo permitindo retomadas de temas sempre que necessário, respeitando o tempo e evolução dos pacientes para a integração psicofísica.

Ao final dos atendimentos do ano de 2004, estavam esgotados os percursos de conhecimento, vivência e integração dos diferentes aspectos do corpo dos pacientes do Grupo.

O "Grupo Corpo" realizou um encontro por semana, com duração de $1: 15 \mathrm{~h}$ por sessão, todas as sextas-feiras, totalizando quarenta e duas sessões.

Ao ingressar no grupo, o paciente é esclarecido quanto aos objetivos e dinâmica de funcionamento, ressaltando-se a importância de sua participação e assiduidade. Há também uma apresentação do paciente aos demais participantes e aos terapeutas.

Durante o ano de 2004, cada sessão do "Grupo Corpo" foi dividida em etapas, a saber:

1. Relato Inicial: de início, cada participante era convidado a relatar por escrito, suas sensações corporais como dor, desconforto físico, alteração da postura, estado mental e emocional naquele momento;

2. Relato Retroativo: os participantes são estimulados a lembrarem o que foi trabalhado na sessão anterior, se seguiram às orientações recebidas e o que transcorreu em suas vidas na semana que passou;

3. Conduta Terapêutica (conforme planejamento e demanda do grupo): alongamentos eram criados pelos pacientes sob a supervisão da fisioterapeuta e, em seguida, são realizados exercícios de consciência corporal, ritmo e coordenação, relaxamento, massagem e/ou auto 
massagem, observação de determinado segmento do corpo humano, desenhos, dança e, por fim, o alongamento geral.

4. Relato Final: o paciente registrava por escrito suas sensações corporais naquele momento e sugestões.

No início da sessão, após os pacientes relatarem como se sentiam naquele momento e as lembranças de como tinha sido a semana pregressa, eram realizados exercícios corporais para alcançarem alívio e bem-estar, segundo as necessidades expostas. Havia um roteiro de trabalho corporal, por segmentos, mas prevalecia aquele escolhido junto com os pacientes.

Definido o segmento corporal do dia, usávamos diversas formas para trabalhá-lo, explorá-lo, conhecê-lo. Norteados pelo uso de um esqueleto humano, às vezes, mostrávamos um Atlas de Anatomia para completar o conhecimento de determinados aspectos, outras vezes 0 paciente desenhava o segmento representando o seu. Também apresentávamos a parte do esqueleto escolhida (usávamos um esqueleto humano), explicávamos aspectos músculo-esqueléticos, quais as possibilidades de movimentos e outras funções pertinentes.

Segundo os registros nos prontuários, realizamos várias condutas terapêuticas que objetivaram a consciência corporal, sociabilização, dentre outras questões. O paciente tentava "conhecer" esta parte em si e no outro pelo toque, pelo olhar, por percussão óssea, por massagens e automassagens, pelo tracionamento da pele e palpação, além do uso de outras técnicas de contato com o corpo, para sentir a presença, condições dos músculos, perceber as ligações desse segmento com o resto do corpo, etc

Partíamos então para os alongamentos dos referidos segmentos corporais, a maioria sugeridos pelos pacientes. Também estimulávamos as possibilidades de movimentos corporais relacionados às suas funções. Um podia repetir o jeito que o outro realizava o movimento, a fim de sentir o efeito deles no próprio corpo e experimentar possivelmente, diferentes sensações. 
Uma análise estatística dos segmentos corporais trabalhados em cada sessão ao longo de 2004 permite uma descrição mais fidedigna do que ocorreu no "Grupo Corpo" de 2004.

Figura 1. Distribuição dos segmentos corporais trabalhados no "Grupo Corpo" a cada sessão ao longo de 2004.

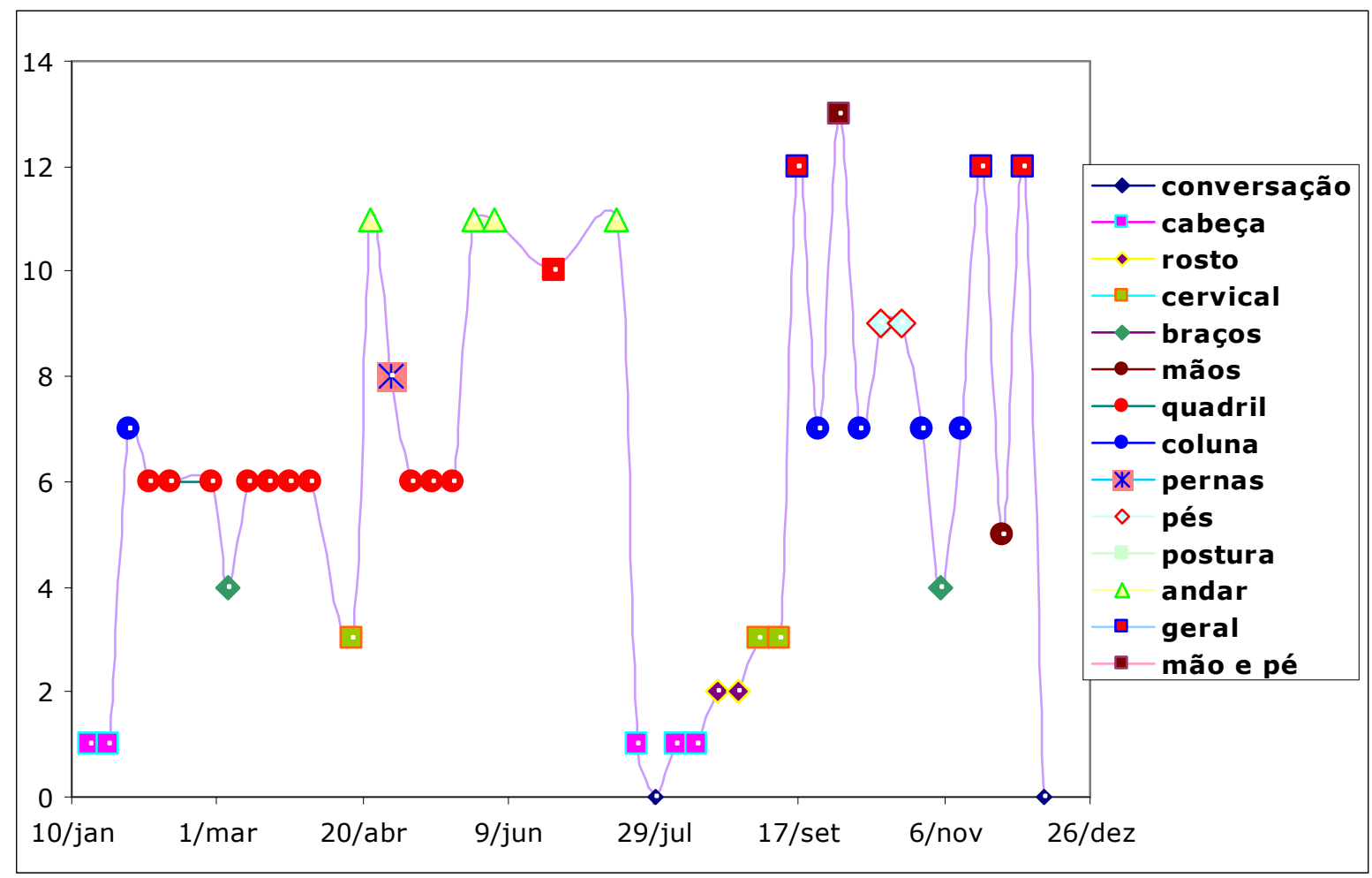

Fonte: Registros de prontuários dos participantes do "Grupo Corpo" de 2004.

Nota: O eixo vertical refere-se aos números convencionados para cada segmento corporal relacionados na legenda acima, à direita e representados no gráfico por símbolos ou números: conversação $=0$, cabeça $=1$, rosto $=2$, cervical $=3$, braços $=4$, mãos $=5$, quadril $=6$, coluna $=7$, perna $=8$, pé $=9$, postura $=10$, andar $=11$, geral $=12$, mão e pé $=13$.

Na Figura 1, pode-se constatar que a seqüência prevista no roteiro, que deveria seguir a seqüência numérica descrita acima (conversação, cabeça, rosto, etc.) não foi seguida. Vemos no gráfico que, em janeiro de 2004, iniciamos pela cabeça, seguida pela coluna e, já na terceira sessão trabalhamos com o quadril, o que se alongou por três sessões; realizamos uma sessão com os braços, mas na seguinte, voltamos para o quadril; considerando a demanda para o quadril tivesse sido esgotada, partimos para o corpo em geral e para as pernas. 
O gráfico aponta que o tema/segmento quadril foi trabalhado em dez sessões, seguido da cabeça e coluna, trabalhadas, cada uma em cinco sessões; quatro sessões para trabalho com o andar; três sessões voltadas para a região cervical e para o corpo em geral; duas para rosto, para membros superiores e para os pés; e, uma sessão dedicada a cada um dos demais segmentos - pés, mãos, postura e membros inferiores.

Dentre essas preferências gostaríamos de destacar a cabeça frente o relato dos pacientes de se interessarem em saber onde se localizava a doença mental, a coluna por referirem um local do corpo onde a maioria sentia dores e alterações posturais.

As tendências ocorridas não foram previstas, pois tínhamos o roteiro como um guia que pretendíamos seguir. Esse fato nos indicou a prevalência das necessidades expressas pelos pacientes sobre o roteiro, o que serviu para afirmar a importância de considerar a demanda dos pacientes. Segundo o ocorrido, parece-nos que um dos meios de se "manter um protocolo" seria não dar voz aos pacientes e seguir "as regras", modo que pouco alcança ou não alcança a integração corporal do paciente.

Ainda pela análise estatística pudemos constatar que alguns dos participantes estiveram presentes na maioria dos encontros, porém outros participaram de forma episódica. A freqüência média de pacientes por sessão foi de 4.57 pacientes, sendo que o maior número de pacientes por sessão foi de meados de fevereiro a maio de 2004 (média de sete pacientes por sessão: mínimo de seis, e máximo de nove). Nestas sessões o tema era quadril/vida sexual, dado que pôde indicar um interesse dos pacientes pelo referido tema.

Pudemos também observar que tanto a freqüência quanto a permanência nas sessões configuraram-se inconstantes. $E$, entre os pacientes, a depender do momento vivenciado, surgiam diferentes manifestações: de gosto por determinada atividade proposta, de aceitação do outro e de si, de expressão de timidez, de distração durante a sessão, exacerbação da fala (gritos, gargalhadas fora de contexto) e do discurso, dentre outros. 
Após vivenciarmos o segmento corporal proposto, experimentamos vários tipos de danças étnicas, mas foi a dança de roda a preferida dos pacientes. A sua simplicidade contribuiu decerto para isso: os dançadores formam uma roda, dão as mãos uns aos outros, virados para o centro do círculo, evoluindo a roda em sentido anti-horário. De vez em quando criávamos passos e coreografias, outras vezes, seguíamos coreografias tradicionais. Antes de encerrarmos o trabalho corporal realizávamos um alongamento geral e /ou relaxamento sugeridos e às vezes coordenados pelos pacientes.

A todo tempo tínhamos a intenção de servirmos de "ponte" e apoio: uma entre outras "pontes" para o indivíduo caminhar em seu processo de reabilitação e apoio facilitador em sua jornada rumo ao exercício de sua cidadania. 


\section{Capítulo V: ANÁLISE E DISCUSSÃO DOS RESULTADOS}

Este estudo foi construído de maneira muito particular, pois inicialmente minha proposta se referenciava em avaliar e reavaliar gestos e posturas dos pacientes em processo de reabilitação no CRHD. Ao perceber que as estratégias fisioterápicas por mim conhecidas corriam o risco de não atender a esses pacientes busquei outro caminho, que mais tarde denominei de fisioterapia ampliada à experiência por mim vivida no "Grupo Corpo". Experiência esta construída "em ato", passo a passo, face a cada acontecimento que vivíamos nas sessões do grupo.

Desse modo podemos dizer que a análise também foi se dando passo a passo. Um acontecimento após o outro foi me conduzindo a determinados autores, conversas com os pacientes, inclusos seus desejos e outras manifestações, contato com a equipe, o próprio desenvolvimento do Grupo, produzindo possibilidades de trocas, a partir das respostas e não respostas. Assim fui construindo um caminho no qual fiquei muito envolvida.

Findado o ano de 2004, estava encerrada a referida etapa de trabalho, motivo desse estudo e em 2005 seguiu-se outra proposta de atividades traçada junto aos pacientes. Ao longo de 2005, já com certo distanciamento do ocorrido em 2004 me senti preparada para conhecer o quê e como havíamos realizado o "Grupo Corpo" em 2004.

\subsection{ANÁLISE DOS DADOS DOS PACIENTES}

Após a coleta de dados dos pacientes, como resultado de reflexão, escolhi apresentar quatro casos, sob o formato de pequenas histórias, que segundo suas características singulares podem representar as vivências dos pacientes no "Grupo Corpo". Cada história "puxa o fio" de outras histórias e de discussões de autores estudados.

\subsubsection{A história de Ana: uma desorganização comovente}

Quando cursava a oitava série Ana começou a apresentar dificuldades em se relacionar com os colegas e em acompanhar a escola. 
Esta situação foi se agravando, apesar dos acompanhamentos psicoterapeuticos e psiquiátricos. Dos 17 para os 18 anos de idade teve alucinações visuais e começaram seus episódios de internações psiquiátricas. Iniciou tratamento no CRHD em 2003 e o "Grupo Corpo" em 2004.

Alta, magra, ruiva com sardas, olhos muito azuis, Ana apresentava marcha lentificada. Com o tronco projetado para frente, acompanhado de uma cifose dorsal, protração da cabeça e protusão abdominal. Entrava na sala, geralmente falando muito alto, às vezes gritando. Faltava frequentemente e atrasava. Notávamos que se esforçava em participar pois tentava responder, fazer exercícios e dançar, mas seu desempenho era entremeado a neologismos, escritas e gestos fora de contexto e de nexo. Seus olhos azuis e profundos eram cheios de significado e angústia.

Ana tinha um comportamento flutuante, entre o lógico e o não-lógico. Algumas vezes tinha grande vontade de não atrapalhar o grupo, sentindo-se com baixa auto- estima, referia que queria que "tudo fosse diferente". Todos queríamos que fosse diferente. Seu estado de sofrimento parecia impresso em suas expressões.

Alguns registros a partir dos seus relatórios:

"Não achei bom... eminhocada,...bondosa..."

“... comprar calça... tato do corpo"

"Mais calma e aliviada, gosto dos meus seios, não gosto do ânus,nem da barriga (citou várias partes do corpo)"

"Fiquei tonta, vi que não é competição, vivemos emoções, tive entrosamento, vi que precisamos de força."

"Meu corpo: destroços. Apoderada pelo que é meu"

"Gosto da aula, disposta feliz por participar" 
"Não quero atrapalhar.. Alegre e adoro o grupo, quero colaborar."

"Contente participo livre sentindo perfume"

"Preciso acalmar meu emocional, suba! Te ilumine"

Tentávamos com Ana um trabalho terapêutico, voltado para a reconstituição da pessoa, voltado para o cuidado e acolhimento, no sentido de buscarmos a transformação dos seus modos de viver, de sentir o sofrimento e seu cotidiano (Rotelli, 1990).

Sobretudo, prestávamos muita atenção no que suas expressões comunicavam o que, aliás, não era difícil, pois muito expressiva, com seu corpo cheio de significados comunicava seus momentos de diversas maneiras. Ana, em meio a neologismos, comunicava tanto seu sofrimento como sua alegria, sua calma ou estados de agitação. Ana chorava, gritava e sorria. Segundo Davis (1979) o sistema de gestos, mímicas e deslocamentos indica o estado em que a pessoa se encontra e seu modo de ver o mundo, o que podíamos constatar em Ana.

Uma das características do nosso Grupo era que os pacientes tinham dificuldades corporais diversas. Conviviam aqueles com seus movimentos rígidos e diminutos com os que realizavam movimentos arrítmicos e amplos. Alguns pacientes tinham um bom ritmo, coordenação, mas todos mostravam uma consciência corporal precária e alterada, um corpo a conhecer, experimentar e reconhecer, segundo Ana "um corpo destroçado a ser apoderado, pois ele é da pessoa".

Embora alguns fossem capazes de seguir os movimentos, referiam não sentir o corpo ou parte dele: como se estivessem anestesiados e ainda falavam que de tão preocupados com sua problemática mental, nunca pensaram que colocar a atenção no corpo, prestar atenção nas diferentes sensações, movimentar-se, poderia lhes trazer bem estar. Achavam o "Grupo Corpo" um "tipo de terapia diferente", que fazia bem "para o corpo e para a mente", que gerava descontração, distração e diversão, onde podiam "aprender e saber coisas". 
Para alguns pacientes, a preocupação com o que lhes tinha acontecido antes de chegarem à sessão, ou problemas familiares era motivo para que ficassem desatentos e não conseguissem participar como gostariam. Como estratégia para que estivessem presentes no momento de nossas atividades pedíamos que colocassem a atenção no corpo, deixassem os movimentos fluírem e um dos pacientes comentou como era para ele essa nossa orientação: “... no "Grupo Corpo” eu ficava numa boa, aí você sempre falava: 'não pensa, segue o movimento'... e isso era bom para mim...ajudava a me despreocupar e eu parava de pensar bobeiras...até hoje eu lembro disso, sigo o que estou fazendo..."

Buscávamos frestas para que pudéssemos ir além das preocupações, pois, segundo Nietzsche, não é questão de ser bom ou ruim, mas achar novas possibilidades que podem estar presentes naquele momento, fluindo, perpassando em nossos corpos como fluxos de força (Keil, 2004; Barrenechea, 2002).

Já para Ana era fácil comunicar-se corporalmente e demonstrou interesse em representar com o corpo diferentes estados emocionais, algumas vezes nos ajudou representando para o Grupo alguém raivoso, triste ou alegre, por exemplo. A partir do que os pacientes podiam ver representado em Ana, pudemos trabalhar aspectos da consciência corporal junto a todos do Grupo.

Após esta etapa os pacientes refletiam sobre a maneira como se expressavam e, se fosse o caso, retomavam o trabalho corporal para experimentarem novos modos de manifestar aquilo que estavam sentindo trazendo à consciência a relação entre a linguagem corporal e a verbal. Isso contribuía para a ressignificação da consciência corporal que por sua vez modificavam os modos de pensar, sentir e agir, o que nos mostrava uma interligação entre a mente e o corpo (Gaiarsa,1991). Além disso, podiam experimentar expressões corporais que proporcionavam sensações de relaxamento, conforto, autoconfiança e bem-estar, o que favorecia o contato com melhores estados emocionais. 
Ao observarmos a comunicação dos pacientes, pudemos notar perfis posturais diferenciados, tanto na sua postura corporal como no comportamento durante nossas sessões. Mesmo assim, segundo nossa avaliação da postura corporal dos pacientes, pudemos observar dois perfis posturais:

1. Coluna com perda das curvas fisiológicas, marcha com pobre ou nenhuma dissociação de cinturas (responsável pela movimentação concomitante do membro inferior direito e membro superior esquerdo e vice-versa, durante a deambulação) e movimentos diminuídos e /ou rígidos;

2. Coluna com acentuação das curvas fisiológicas, protusão abdominal pouca ou boa dissociação de cinturas durante a marcha, movimentos diminuídos e desleixados ou movimentos amplos com pobre noção de limites corporais quanto à amplitude de movimentos e força muscular.

Desse modo, pudemos notar que embora o número dos pacientes estudados não cumprisse as expectativas para uma análise quantitativa, o que, aliás, não é objetivo desse estudo, nos chamou a atenção à possibilidade de agrupar os pacientes por perfis posturais, sugerindo-nos que as posturas físicas foram mais constantes que os modos de participação dos pacientes nas sessões. Pudemos também relacionar que muitas vezes a presença de mudanças posturais estavam relacionadas às mudanças dos estados de humor, confianças, aos modos como o paciente conseguia participar, à sua consciência corporal, dentre outros

Mesmo que tivéssemos observado que o agrupamento dos perfis posturais tivesse sido mais constante, não contemplamos nesse estudo categorias nem classificações desses, pois além de não ter sido nosso objetivo, demandaria outro tipo de estudo, muito embora, através dos autores aqui referenciados relacionados à comunicação não verbal, pudemos constatar uma correlação entre as posturas corporais e estados emocionais.

Para Ana durante as sessões em que protagonizou essa vivência, resultaram em diminuição dos neologismos, melhora de sua auto-estima e 
participação das atividades propostas no Grupo. Entretanto, cabe destacar que, na maioria das sessões, Ana mostrava-se angustiada, com baixa autoestima.

Ana encerra o ano, muito desorganizada, com gestos e fala fora de contexto, desanimada, agressiva em casa (segundo a mãe) e pediu para ser internada. Foi avaliada e internada no IPq retomando alguns grupos do CRHD, pois suportava poucos estímulos.

Após a internação, Ana retomou seu tratamento de reabilitação em 2005. Em 2006, quando liguei para casa da Ana para convidá-la a participar da entrevista sua mãe disse que duvidava que Ana se lembrasse de algo, pois tinha piorado muito daquela época para cá e atualmente se lembrava muito da época da infância, na escola e nem se lembrava dos técnicos que a estavam atendendo atualmente. A mãe achava que seria um tempo perdido. Mesmo assim pedi para falar com Ana, que aceitou o convite mesmo relatando lembrar-se vagamente do "Grupo Corpo".

Durante a entrevista, quando abordada sobre o significado do "Grupo Corpo", ela disse: .."tudo que a gente aprende é pegar o que pode..." .E encerra dizendo que não lembra de mais nada.

\subsubsection{A história de Lúcia: uma talentosa dançarina sem limites}

Lúcia freqüentou a escola normalmente até os 8 anos de idade, quando apareceram atitudes agressivas e de isolamento. A partir daí, se submeteu a inúmeros tratamentos, até ingressar no CRHD em 2003.

Lúcia tinha indicação terapêutica da equipe para iniciar nosso grupo naquele mesmo ano, mas não queria, pois relatava não gostar de dança. No transcorrer de 2003, foi se aproximando e ao experimentar o Grupo em janeiro de 2004, gostou de dançar e ficou conosco por sete meses.

Era assídua e participativa a seu modo, pois tinha dificuldade em permanecer na sala durante a sessão e aceitar várias das atividades propostas. Alta, com o tronco projetado para trás e protusão abdominal, entrava na sala a passos largos, sem dissociação de cintura, com voz forte e alta, falava e cantarolava, às vezes de bom humor. Sorria, mas no momento 
seguinte, podia agir autoritariamente ou ficar muito brava. Vestia-se bem colorida, geralmente com vestidos rodados, maquiada, de batons e unhas esmaltadas de cores fortes sempre tinha seus cabelos tingidos de vermelho ou loiro também em tons fortes.

Com ela, não pudemos realizar uma comparação entre o relatório inicial e o final, pois às vezes não preenchia nem um nem outro, escrevia em cima da escrita inicial, outras vezes escrevia em outra língua, contava histórias extraordinárias, no final poucos deles foram compreensíveis. Os relatórios seguiram desse modo até o final do tratamento, como veremos a seguir:

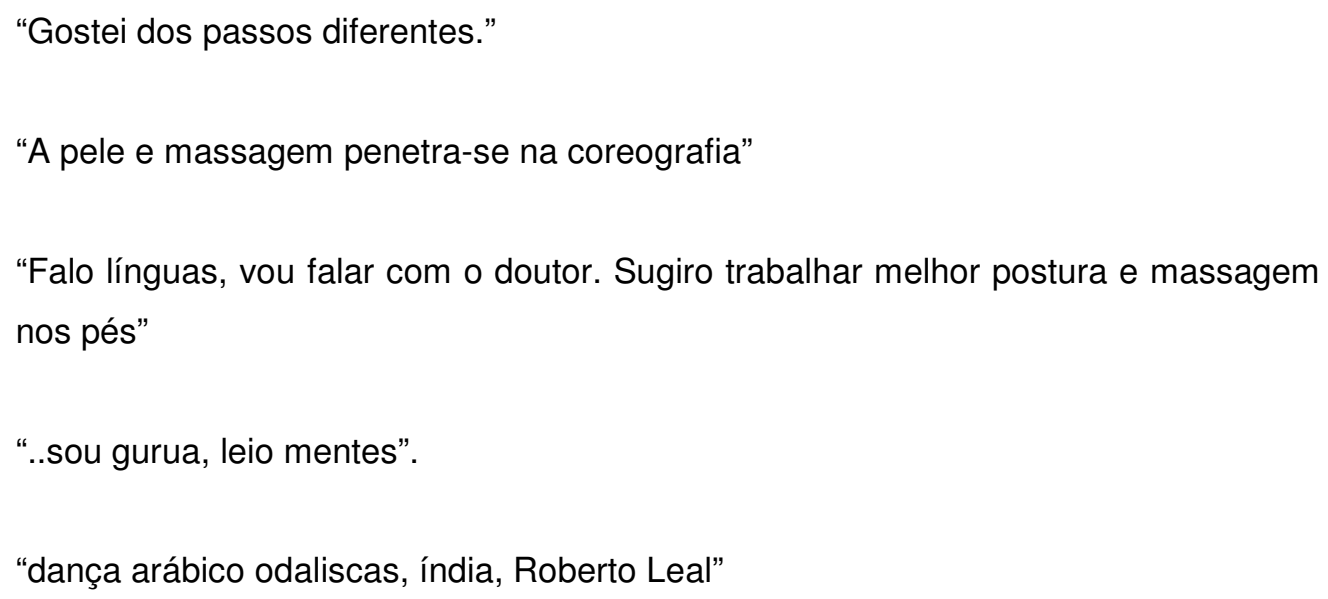

Queria sempre coordenar o grupo para dançar e ensinar os passos da dança que escolhia. Além de movimentar o grupo, criava sempre um tumulto que às vezes acabava fluindo segundo proposta aceita por nós, por estar um pouco mais organizada naquele dia, ou acabava contribuindo para momentos de grande confusão ao invadir limites dos participantes ou não aceitar as regras que o grupo mesmo construía.

Ao longo do tempo Lúcia aceitou permanecer na sala durante o Grupo. Certamente sua presença ou ausência não passava "em branco" para todos nós. Lúcia tinha um bom ritmo, aprendia as danças com facilidade e usava sua imaginação para criar performances. 
$\mathrm{Na}$ ocasião de sua alta Lúcia coordenou as partes da dança em algumas de nossas sessões embora tivesse dificuldade em participar das conversas e exercícios com o corpo, mas aceitava ficar conosco na sala. Não notamos modificações em sua postura e gestos. Foi encaminhada a um centro de convivência.

Vinte e três meses depois de sua alta, quando liguei para convidá-la a participar da pesquisa Lúcia mostrou-se receptiva, embora não tivesse aceitado o local de CRHD como minha sugestão para a entrevista, dizendo que não gostava de ir lá. Pediu que eu fosse até sua casa. Dias depois eu estava lá e fui recebida afetuosamente por Lúcia. Fiquei surpresa, quase não a reconheci, pois a encontrei com muitos quilos à mais, vestida como uma senhora, sem maquiagem e com cabelos escuros e discretos: uma sorridente senhora.

Mais tranqüila do que na ocasião de sua alta, disse que freqüenta outro hospital-dia onde faz pintura e outras formas de arte, mas "não faz nada para o corpo, pois lá não tem".

Lúcia me recebeu em seu quarto, permaneceu semi-deitada, com um cobertor, num dia quente, comendo uma baciada de pipocas. Pediu que eu ficasse sentada ao pé de sua cama, com seu cachorrinho em cima da cama, que volta e meia latia além de me morder, pois parecia ter ciúmes de Lúcia.

No meio disso tudo Lúcia conversava comigo e gritava com o cão dando-lhe uns sopapos para que ele parasse de latir e/ou morder, o que tinha um efeito temporariamente curto.

Lá estava Lúcia, cheia de pipocas na boca, coberta num dia quente e entusiasmada com a entrevista. É claro que ela quis dirigir as perguntas e respostas, por exemplo, só respondendo as minhas perguntas à medida que eu ouvia até o fim alguma história de algo que lhe aconteceu e que não era assunto da entrevista mas que queria me contar até o fim. Isso me fazia pensar como era grande sua necessidade de ser ouvida.

Ao responder em como tinha sido para ela sua participação no "Grupo Corpo" iniciou contando exatamente sobre o quê das sessões relutava em 
participar, as partes do corpo, embora o que realmente preferisse fosse a dança:

"ah... eu acho que foi um grupo importante porque esse grupo mostrava não só os..os ...como é que se diz...as partes do corpo e também os diversos tipos de dança e eu gosto muito de dançar... preferi a dança árabe"

E, realmente ao realizarmos a dança árabe, Lúcia ficou muito estimulada, querendo dançá-la por várias sessões e fez uma coreografia, trazendo de casa um lenço especial para essa dança e ensinou-a aos pacientes. Lúcia montou uma estória de uma dançarina árabe e baseou-se nela para montar a coreografia.

$\mathrm{Na}$ entrevista falou no que o grupo a ajudou muito:

\begin{abstract}
"Ah....me ajudou...me ajudou...em ter uma certa noção de um certo tipos de dança que eu não conhecia, me ajudou a ter noção do corpo que eu também não conhecia, vamos supor assim, os nomes que eram diferentes do que a gente costuma falar, por exemplo a perna, nossa que aqui chamava assim... assim... assim, entendeu? Então cada parte do corpo tinha um nome diferente, um nome esquisito."
\end{abstract}

"Eu gostei, porque fica guardado na memória, porque eu agora tudo o que minha mãe perdeu de memória assim, de coisas fáceis, eu aprendo fácil porque eu aprendo tudo na memória, eu não preciso escrever..."

Curiosamente, um dos seus relatos na entrevista nos chamou a atenção, foi quando perguntei se gostava de participar do "Grupo Corpo", ela respondeu assim: "Mais ou menos porque eu gosto de dançar porque eu não gosto de mil explicações. Poucas explicações já basta, entendeu? Se for só dança tá ótimo!"

Como uma "ficha que cai" pude entender que possivelmente Lúcia não gostava realmente de preencher os relatórios, nem de fazer os exercícios, pois sua afinidade era com a dança, pois estavam ali os seus talentos: bom ritmo e coordenação, movimentar o corpo pela musica e dança, sua criatividade a ajudava a se organizar, a ponto de ensinar! 
Ainda na entrevista fala que após sua alta ensinou uma amiga a dançar:

"Ah...ahhhhhhh minha amiga não sabia dançar lambada e fui eu que ensinei.... e ela é gorda heim!!!..."

Lúcia relatou que tem consciência que está muito acima do seu peso, mas podemos dizer que ela nos ensina com essa fala sobre a 'amiga gorda' que para dançar não é necessário emagrecer.

Dentre outras questões podemos aprender com Lúcia que tinha em sua "falta de limites" sua linha de fuga e fugia do poder da captura, da homogeneização (Rolnik,1995) ao rebelar-se em não querer ficar na sessão, exceto na dança. Podemos considerar que essa era a maneira que Lúcia tinha de buscar autonomia, liberdade que alcançava ao encontrar o espaço lúdico.

Durante as sessões, procurávamos com a música e a dança promover a ludicização (lúdico, do latim ludus: jogo) do movimento corporal, como forma de aprender. Para isso tentávamos desenvolver uma legitima qualidade do brincar para descobrir o verdadeiro prazer do movimento do próprio corpo.

Essa era uma estratégia que favorecia a diversidade e a legitimidade dos desejos ao mesmo tempo em que tinha intenção de favorecer 0 desnudar da máscara dos mitos corporais, como por exemplo, o desejo de se manter em constante equilíbrio frente ao medo do descontrole, motivo tanto de fascínio quanto de aflição.

Tal como ocorreu com Lúcia, foi durante as atividades de música e dança que os talentos corporais de outros pacientes apareciam, eram reconhecidos e experimentados. Observávamos uma mistura de facilidades que os pacientes descobriam em seus movimentos corporais (seus talentos) com dificuldades para determinados movimentos, coordenação e/ou ritmo segundo manifestação de sintomas do acometimento a que estavam sujeitos. A descoberta e vivência dos talentos ampliavam a auto-estima, autoconfiança, favoreceram o estabelecimento de contato, os processos 
sociocomunicativos, a motivação, o autodesafio, o afastamento de problemas e o desenvolvimento sensorial/ físico/motor, além de minimizar a importância que se dava à manifestação dos sintomas dos transtornos mentais enquanto impossibilidade de realização de vida.

Tínhamos o aspecto lúdico como uma maneira de expressão que pela despreocupação, pelo faz-de-conta, podia deixar o corpo aberto aos imprevistos, às novidades, o que fazia do lúdico, força de potência para recriar as minúsculas situações do cotidiano.

$\mathrm{Na}$ literatura, a música unida à dança são consideradas fatores de contribuição para a reabilitação de pessoas com psicose, como cita Langslet (1991), por exemplo, ao falar que a música e a dança parecem estar enraizadas nas camadas mais profundas de nossa personalidade, onde percepções sensoriais, sentimentos e pensamentos se integram e segundo Frohne (1991), essa estratégia ajuda a desenvolver expressão dos sentimentos, experimentação da fantasia, a assimilação de normas satisfatórias e a rejeição de normas negativas, materiais reprimidos, impulsos, áreas dissociadas da personalidade, ajuda a diferenciar a percepção do corpo e seus limites, desenvolver a capacidade do paciente de pleitear um lugar nesse mundo e lidar com a proximidade e distância.

Pensamos que essas hipóteses podem ser relacionadas à organização que Lúcia encontrava ao dançar e fazer coreografias, onde podia usar seu potencial criativo, aspecto que the era singular. Essa singularidade, enquanto potencial criativo relacionado à autonomia, não pareceu ser consciente para Lúcia e nem foi para nós, terapeutas, naquela época.

Cabe ressaltar que quando procuramos dar voz e vez aos pacientes, muita coisa pode escapar em nossas leituras, em especial aqueles que envolvem o inusitado, pois pegos de surpresa, corremos o risco de não percebermos os talentos do corpo postos ali, aspectos perceptíveis após reflexão. Podemos pensar então, que a clinica ampliada envolve periódicas reflexões junto ao paciente. . 
Atualmente Lúcia não realiza exercícios físicos, freqüenta um centro de convivência tem aulas de cerâmica e continua morando com a mãe.

Lúcia afirmou que, se houvesse um "Grupo Corpo" só de dança, para ex-pacientes, ela gostaria de freqüentar.

Ao final da entrevista, Lúcia e a mãe despediram-se de mim afetuosamente e a mãe me convidou a visitar Lúcia toda vez que eu quisesse... Fui embora carregando seu cachorrinho em meu calcanhar até entrar no elevador!

\subsubsection{A história de Alice: uma flor que desabrochou no "Grupo Corpo"}

Alice atuava como enfermeira em UTI em dois hospitais e dava aulas em escola de enfermagem. Muito ligada ao pai e uma das irmãs, sofreu de depressão após a morte dos dois, seguida de alucinações auditivas e visuais. $\mathrm{Na}$ ocasião não quis mais se alimentar e seguiu com comprometimento cognitivo severo, levantando suspeita de quadro demencial. Após algumas internações, inclusive por tentativa de suicídio, Alice iniciou tratamento no CRHD.

Pouco assídua Alice entrava na sala a passos pequenos e cautelosos. Cabisbaixa, trêmula, com expressão facial empobrecida, tronco projetado para frente, sem dissociação de cinturas durante a marcha, pobre movimentação de membros superiores, sentava-se cuidadosamente próxima a uma mesa onde todos respondiam o relatório e permanecia lá. Com olhar fixo no horizonte, nos respondia localizando-nos com um breve contato visual, às vezes com uma resposta verbal simples, como "sim", "não" ou "não sei". Alice não conseguia escrever e normalmente desenhava pequenos vasos com flores. Com seu jeito doce, mostrava grande esforço em estar presente. Uma das vezes desenhou uma cesta de frutas e disse que era para todo o grupo e ao realizarmos os exercícios permanecia conosco, embora calada, às vezes tentava algum movimento, mas na maioria não os completava. 
Em março daquele ano começa a escrever "Saudades daqui.....Mas evolui ainda com dificuldade de contato, às vezes não conseguindo escrever, voltava a desenhar.

Aos poucos foi ficando mais presente, aumentando suas percepções e ampliando seu contato, referia quando se sentia fraca, contente, bem, com dores lombares.

Ao realizarmos avaliação fisioterápica e exame de imagem, em razão do quadro de lombalgia referido por Alice, foi detectada hérnia de disco lombar e foi encaminhada para tratamento de RPG.

Nessa época, outubro de 2004, Alice participava das atividades, expressava-se melhor e realizava as danças com boa coordenação e ritmo, embora ainda lentificada, mas foi durante o ano de 2005 e 2006 que conseguiu estar mais presente no sue cotidiano, melhorar seu ritmo de participação e referiu na entrevista que durante as sessões de RPG, pôde experimentar outras posturas corporais mais eretas e modos de andar mais flexíveis e confortáveis, e que ao olhar-se no espelho gostava mais do que estava vendo e sorrindo sentia-se mais satisfeita. Contou sobre suas inseguranças, o quanto se incomodava em falar de si nos grupos de atendimento pois não gostava de se expor para outras pessoas. Atualmente Alice não realiza RPG, pois não conseguimos dar seqüência ao seu tratamento, mesmo assim teve alta com diminuição sensível das dores lombares e recebeu orientações de exercícios domiciliares: “... eu me espreguiço até hoje e mais os exercícios que faço em casa me fazem diminuir mais ainda a dor lombar."

Assim como Alice, todos os pacientes recebiam orientações domiciliares, através de recomendações, por exemplo espreguiçar-se habitualmente, orientações ergonômicas, exercícios gerais e especificos.

Com isso tínhamos o objetivo de que, além de proporcionar um meio de que pudessem se lembrar do que tínhamos feito na sessão pregressa, sobretudo que ficassem em contato com seu corpo através dos exercícios, como meio de estarem mais presentes no seu cotidiano e conseqüentemente ampliar suas trocas (Saraceno, 1996) 
A maioria dos pacientes nos revelou nas entrevistas que espreguiçam-se até hoje; dentre todos os exercícios este foi o que realmente realizam, disseram. Falaram que, antes do "Grupo Corpo", não tinham esse hábito e sentem prazer quando o fazem, especialmente para "tirar a preguiça para iniciar o dia, falando 'Bom Dia', como costumávamos fazer no Grupo.

A participação da família nesse processo era importante tanto para que os pacientes se lembrassem, quanto para que pudessem ter melhores condições de autonomia, quanto para o estreitamento de vinculo entre eles. Observávamos que os familiares não participavam do que acontecia em nosso Grupo, portanto também destinávamos algumas orientações a eles. Durante as entrevistas os pacientes disseram que haviam tentado envolver os familiares sem sucesso: ou os familiares não davam importância, ou os realizaram somente no início:

\footnotetext{
"Ah...eu cheguei a ensinar pra minha mãe, tipo assim, de estender ...pra relaxar ... e também ensinei aqueles passos de dança pra ela, pra poder relaxar as pernas, pra ter mais flexibilidade, mais equilíbrio, mais forte, mais firme... Ah... Eu não vou mentir... ô mãe você quer, vc quer aprender a fazer as coisas que eu aprendi lá da professora Eliana...minha mãe chega muito cansada, fica com dores nas costas, dores nas pernas. Eu falo: 'mãe isso é falta de exercício, você precisa fazer... eu vou te ensinar uns exercícios que eu aprendi na Clínica..." (Mario)
}

Quando Ihes perguntamos se ainda continuavam a fazer as massagens que orientamos evidenciamos, que aqueles que tentaram realizar nos familiares também não conseguiram, como nos mostra abaixo uma paciente:

“... a massagem tinha importância pra mim....quando faço massagem na minha mãe... raramente ela pede...é...quando ela pede, acho que ela nem pede mais a essas alturas, nem sei...." (Simone)

Como resultado dessa experiência realizamos sessões com a presença e participação dos familiares, o que aconteceu em 2006, pois sabemos que os pacientes precisam de apoio e entendimento do que 
realizam para que possam estabelecer novos valores, novos ordenamentos em suas vidas (Kinoshita, 1996), sem falar que realizar os exercícios junto com o paciente, ou participar estimulando-o, pode ser um modo interessante de cuidado.

É interessante notar que no início de sua entrevista, Alice disse que não se lembrava de nada, pois para ela, o ano de 2004 parecia "estar em branco", mas curiosamente, ao darmos um tempo para quem sabe se lembrasse de algo, relatou alguns aspectos das atividades, das conversas e dos relatórios:

"Lembro que nós fazíamos um grupo e falávamos das partes do corpo. Isso é que eu consigo me lembrar, que nós fazíamos atividades em grupo. Agora estamos fazendo mais exercícios em pé, mas antes tínhamos uma discussãozinha em grupo... lembro dos relatórios".

O ano de 2004 foi realmente marcado pela realização das sessões através dos segmentos corporais e os relatórios, o que findou em dezembro daquele ano, desse modo parece que Alice lembra de algo daquela época, embora não tivesse conseguido localizar-se temporalmente.

Alice não conseguiu atribuir um significado aos relatórios devido sua falta de memória daquela época, mas os outros pacientes tiveram diversas opiniões.

Para alguns o relatório era um meio de perceberem como se sentiam no início e no final da sessão, diziam que ao escreverem no início contribuía para que prestassem atenção em si e, depois de escrever, no final da sessão, podiam voltar no seu relato inicial e comparar as diferentes sensações entre antes e depois da sessão.

Para outros, o relatório servia como um lugar de desabafo, quando, por exemplo, podiam escrever o que lhes havia acontecido antes de sair de casa, como uma briga, ou algo que ocorreu no trajeto até o CRHD, como disseram:

“...ter sentido angústia no metrô"., “...vi um incêndio no caminho...” (Rita) 
Curiosamente alguns relataram na entrevista que inicialmente sentiam dores no estômago, ânsia de vômito durante o trajeto de suas casas ao CRHD, mas que com os desabafos nos relatórios, conversas e exercícios que fazíamos esses incômodos cessaram:

“... eu tinha aquela ânsia de vômito e aquilo passou depois eu voltei a ter e depois passou de novo... eu acho que foi exercício mesmo, eu acho o que ajudou foi bastante exercício e bastante conversa também..o desabafo nos relatórios também". (Mario)

Como podemos evidenciar os pacientes contaram que, após escreverem e estarem lá conosco, ficavam mais tranqüilos, conseguiam estar mais presentes no grupo e participar mais.

Como uma de nossas estratégias usávamos a escuta e o acolhimento, que segundo Rolnik (1995), podem ser possibilidades para a aquisição e desenvolvimento da confiança, auto confiança e entrega do paciente. Talvez por isso tivessem sido atribuídos vários significados aos relatórios, por parte da maioria dos pacientes.

Como Alice nos contou durante a entrevista que não se lembrava "direito das coisas" que Ihe aconteceram em 2004, optamos em conhecermos o significado do "Grupo Corpo" para ela e como se sente hoje em dia:

"Gosto muito de participar do "Grupo Corpo", me sinto melhor na parte emocional, porque me sinto mais participativa e acho que isso é bom, antes eu faltava muito. Agora presto mais atenção, os exercícios ...o bate papo. Gosto mais da dança, os passos são gostosos. Gosto daquela em que fazemos assim, assim, assim....acho gostoso, divertido"

"O "Grupo Corpo" me ajudou por que... eu sou muito fechadona, quando eu participo desse tipo de grupo eu me solto, me exercito, é válido... me solto em outros grupos" 
Quando pergunto se se sente mais presente hoje em dia, responde que:

"às vezes dou uma escapada, não só neste grupo, mas nos outros também...fico tensa porque você pode me perguntar alguma coisa e justo naquele momento eu não estar lá. Procuro prestar atenção pra isso não acontecer."

Ao perguntarmos se havia alguma sessão no "Grupo Corpo" que foi especial para ela, contou-nos sobre a sessão em que pedimos que escolhessem uma gravura que Ihes chamasse a atenção. A maioria escolheu a de uma pessoa no fundo do poço, tal como ela.

A atividade proposta foi a de imitar esse gesto e imaginar como poderíamos sair dele. Os pacientes realizaram gestos e construímos uma coreografia a partir deles. Ao realizar o trabalho de "sair do poço", tanto Alice quanto outros pacientes relataram perceber diminuição das dores, relaxamento muscular e mudança nos gestos e posturas em si e nos outros membros do grupo.

Alice nos contou que para ela essa experiência foi "boa e forte", foi difícil encarar o fundo do poço e marcante pode sair dele.

Essa foi uma das oportunidades em que os pacientes nos pediam para realizarmos as atividades propostas junto com ele. Diziam estar interessados em saber dos efeitos sobre nós "os profissionais terapeutas, pessoas normais", além de compartilharem conosco como parceiros, aqueles momentos. Embora no papel de coordenadores na maior parte da sessão, estávamos sempre todos juntos, podendo vivenciar várias faces de uma situação.

Quando observávamos Alice no nosso Grupo,no início de 2004, não tínhamos idéia do rumo de sua evolução frente sua apatia, falta de verbalização, movimentos corporais e ainda a suspeita de um estado demencial. Desse modo partimos para o olhar de Niezsche (Keil,2004), "para além do bem e do mal", o que nos ajudava a não buscar respostas, mas abrir portas e experimentar possibilidades (Rotelli, 1990). Também observávamos qual atividade poderia trazer Alice para um melhor contato 
com a realidade e participação no Grupo, através das suas possíveis afinidades, descobrindo elementos que the favorecessem a sensação de pertencer ao Grupo (Maffesoli, 2005). E encontramos essa "vibração em comum" nos trabalhos de consciência corporal, no lúdico, na música e na dança. Esses meios foram um bom caminho para o encorajamento, enfrentamento (Langslet,1991) e reapareceu em Alice "o samba no pé", como costumávamos dizer. O lúdico ajudava Alice a estar mais presente, melhorar sua participação e pô-la em contato com aspectos do seu passado, como a facilidade em dançar. Esses momentos tornavam seu olhar cheio de significados e traziam sorriso em sues lábios.

Os exercícios que faziam Alice sentir o corpo, traziam-na mais presentes no cotidiano, era mais fácil e mais rápido sentir os trabalhos corporais em si e isso contribuía para que conseguisse se "desligar mais" das preocupações . Em conjunto com todo tratamento de reabilitação, sentese mais segura em relação às suas atitudes em sua vida.

Da mesma forma relataram esses efeitos, outros pacientes durante as entrevistas e pudemos notar esses aspectos também, pelos dados dos prontuários.

Os pacientes falaram que muitas das dores musculares, sensações de angústia e medo passavam no decorrer das atividades de consciência corporal, o que pode ser atribuído tanto aos exercícios de reorganização de posturas e gestos quanto à busca dos sentidos nas expressões e no quê não se conseguia expressar. Frequentemente falavam que no Grupo podiam colocar-se, expressar-se verbal e não verbalmente. Outras vezes diziam que exercitar o corpo com "a mente ligada nele" os permitia perceber estados de conforto, desconforto e muitas vezes eram capazes de expressar o que não conseguiam falar.

No decorrer da prática dessas atividades podíamos observar que os pacientes que costumavam chegar agitados, terminavam a sessão mais presentes, relaxados, alegres, e participantes do contexto daquele momento. Os pacientes com alteração do ritmo e coordenação motora, ao praticarem os exercícios e a dança também saiam mais relaxados e participantes 
daquele contexto, alcançavam uma melhor performance e diziam ao sair que se sentiam "mais leves"

Eles também disseram que, com a participação nas atividades do "Grupo Corpo", "mexer o corpo é bom e melhora a mente." (Helena)

O modo como se comunicavam no Grupo ocorria de diversas formas: alguns pacientes colocavam com naturalidade suas inquietações, outros diziam sempre estarem bem e fortes, enquanto outros, como ocorreu com Alice durante alguns meses, nem se manifestavam. De qualquer modo, observávamos que a auto-estima dos pacientes, geralmente afetada, aumentava à medida que conseguiam realizar as atividades, quando conseguiam colaborar com o outro ou quando percebiam que o outro também tinha limites.

Desde então muito aconteceu na evolução de Alice e hoje ela tem uma boa comunicação, bom ritmo, bom alinhamento do eixo corporal, dissociação de cinturas e movimentos dos membros superiores. Tem bom contato e boa participação no nosso grupo. Realiza estágio no CRHD e está em fase de alta. Ainda cheia de planos para sua vida, ressignificou sua vida.

Alice termina a entrevista dizendo: "eu estou bem e que isso me ajuda muito na parte emocional".

5.1.4 A história de João: um paciente marcante para todos do "Grupo Corpo"

Ao ingressar no "Grupo Corpo", João entrava na sala com marcha lentificada e rígida, apresentava principalmente um quadro de distonia cervical esquerda com acentuado grau de flexão lateral da coluna cervical, escoliose dorsal côncava à esquerda e lombar côncava à direita, hipertonia leve com déficit de coordenação motora fina para ambas as mãos, déficit dos órgãos fono-articulatórios resultando numa fala lentificada, monotônica, com dificuldade para articular as palavras.

O mais assíduo entre os pacientes, bem asseado, arrumado e educado, João dificilmente sorria durante o Grupo e, quando o fazia esboçava seu sorriso num desvio de rima: parecia uma mistura de tristeza, 
certa ausência, desânimo e timidez. Habitualmente entrava na sala e procurava ficar num mesmo lugar.

Ao investigarmos a causa das suas alterações neurológicas nos deparamos com duas possibilidades: efeito colateral dos fármacos e/ou lesão central devido a um acidente automobilístico que João sofrera aos 12 anos de idade. Segundo dados do prontuário e entrevista com o tio (responsável por João), ele foi acometido de TCE, ficou em coma por alguns meses evoluindo com hemiparesia à esquerda com remissão total do quadro após um ano de tratamento fisioterápico. O surto psicótico teria acontecido anos depois, no Japão, quando ele, a mãe e o irmão estavam em viajem para trabalhar e lá morar, após a morte do pai por acidente automobilístico. Medicado no Japão, voltou ao Brasil com a mãe para iniciar tratamento psiquiátrico e não souberam dizer se a distonia se manifestou no Japão. Em 2002, após iniciar tratamento no CRHD, sua mãe veio a falecer de câncer. Após tentativa de morar com o tio e a família, o que não deu certo pela agressividade que João apresentou na época, passou a morar sozinho.

Inquirido sobre sua vida pregressa João relatava ter poucas memórias, praticamente nenhuma. Pedimos então que trouxesse fotos suas, realizamos nova entrevista com o tio e com uma prima de sua mãe, já que o irmão reside no Japão. Pouco puderam acrescentar.

Após uma busca com o tio, João trouxe três fotografias: em duas estava sorridente, com mais ou menos 5 e 8 anos de idade, junto dos seus familiares em festa de aniversário e apenas na outra, logo após a morte de sua mãe, se nota a presença da distonia cervical.

João tinha sua identidade fragmentada até essa ocasião e se deu conta que não se lembrava do seu passado ao investigarmos esse assunto. Tal fato, que inicialmente lhe parecia sem importância, pois dizia que isso não ia modificar sua atual situação, foi tomando relevância, pois ficou interessando em saber da sua história e as lembranças que vinham o ajudavam a entender muitos aspectos do presente. Hoje em dia, segundo sua entrevista, disse que através das atividades do "Grupo Corpo" foi aos poucos se lembrando do seu passado e que isso foi ajudando-o a lembrar-se 
de mais coisas:" deu pra eu lembrar de coisas que eu fazia desde quando eu era pequeno na escola.. isso ajudou a melhorar a minha mente."

Frente ao exame de tomografia cerebral que acusou hipotrofia cortical generalizada e demais exames realizados, foi estabelecida presença de lesão central ainda com causa a esclarecer.

João seguiu com o tratamento de reabilitação no CRHD, encaminhamento para RPG (Reeducação Postural Global) e aplicação da toxina botulinica (para a musculatura acometida pela distonia) num centro de reabilitação.

João respondia os relatórios costumeiramente relatando chegar "bem" e sair "leve" da sessão. Ao estimularmos João a perceber as diferenças entre as possíveis sensações corporais, antes e após nossos trabalhos, começou a relatar o quanto seu pescoço "torto" Ihe incomodava:

"Incomoda pescoço torto, os outros olham,... tenho vergonha...não dá prá andar na rua e arrumar o pescoço... É engraçado quando as crianças olham meu pescoço torto, parece que estão me encarando... Estou duro... Tenso no lado esquerdo... Olhei meu tronco e estava torto.."

João tinha vergonha na rua, ficava chateado e quando tentava corrigir o pescoço não conseguia. Após orientações fisioterápicas domiciliares, às vezes conseguia alinhar o pescoço. Por um lado, João caminhava para uma consciência corporal mais presente, mas por outro, foi fixando-se na importância do seu pescoço torto. Durante aqueles meses parecia que para João sua existência se resumia em "um pescoço torto" e nada mais.

Durante a entrevista João lembrou-se dessa época e disse que pôde sentir mais facilidade em se movimentar ao realizar as nossas atividades.

“..eu tinha a cabeça mais tombada que agora, tinha escoliose...após cada sessão eu sentia que era mais fácil mexer o corpo.... sentia mais leve, melhor, o meu corpo mais fácil para se movimentar." 
Em 2004, seguimos com nosso trabalho no "Grupo Corpo" e apesar de sempre falar sobre seu inconformismo em relação ao seu pescoço torto, João se mostrava interessado nos assuntos que envolviam o corpo de modo geral, independente do segmento apresentado. Seguem depoimentos que João registrou nos relatório ao término de algumas sessões :

“...Foi legal, vi a espinha do esqueleto ...meu corpo e a cabeça estão mais leves..."

“... Gostei de aprender sobre sexualidade..."

"Após a dança sai com o corpo mais leve... Sensação boa ao aprender passos de dança..."

“...estou mais flexível e relaxado (aqui descreveu várias partes do seu corpo"

"... Gostei de saber sobre o cérebro... Sai melhor que entrei após fazer alguns exercícios."

Em dado momento João manteve a conduta de relatar que entrava e saia bem da sessão sem mais falar do seu corpo. Nessa época, dizia que queria um "remédio para preguiça" e observávamos sua baixa tolerância ao enfrentamento de dificuldades. Para ele, os passos da dança também estavam difíceis de acertar, o que the incomodava significativamente. João apresentava alteração de ritmo, coordenação e equilíbrio corporais. Mesmo assim, procurava participar e percebíamos isso através do seu contato visual (prestava muita atenção) e discursos coerentes (apesar de curtos!). Embora relatasse preguiça tentava acompanhar os exercícios, os passos de dança e assim ia melhorando sua performance. Nessa época João já sorria e não se fixava num só lugar na sala do nosso atendimento. João ficava mais próximo das pessoas e participava das conversas. João relatou na entrevista que fez amizades no "Grupo Corpo".

Todos os pacientes relataram ter construído bom vinculo no "Grupo Corpo". Percebíamos uma contribuição entre eles, que se manifestava através de uma ajuda, palavra de consolo, sentar-se próximo, olhar 
significativo e outras expressões faciais. Notávamos essa intenção mesmo naqueles que, durante o tratamento preferiam ou não conseguiam se colocar, o que, naquela época, freqüentemente nos dava sensação de aparente isolamento, não participação;

Cuidávamos e acolhíamos os pacientes que faziam o mesmo entre si, e essa forma de participação nos fazia pensar no espaço que criávamos composto da fusão das subjetividades individuais, formando os espaços de intersubjetividade. (Rolnik, 1995). Esses espaços compunham o ambiente do Grupo produzindo significados, inclusive contribuindo para a construção de vínculos e amizades tão referidas pelos pacientes e observadas por nós.

Para Greiner (2005), é no ambiente que se organizam as relações, e que a pessoa dificilmente pode ser vista a parte dele. Um no outro se constroem o tempo todo. Pensamos que o espaço de intesubjetividade que construíamos, era composto por inúmeros aspectos e que muitos podiam estar fugindo às nossas percepções naquele momento, pois estávamos também inseridos nele. Mas sabíamos que ali estava uma produção de significados e constantes ressignificados a partir dos estados em que se encontravam os participantes, das intenções, desejos, esforços, acontecimentos, etc.

Isso talvez tenha contribuído para o estabelecimento de um vinculo significativo no Grupo, pois muitas vezes eles se ajudavam a partir de sua própria iniciativa. Durante as entrevistas todos relataram a sensação de saudades do grupo e dos participantes, dizendo que no grupo estabeleceram laços de amizade: '“... era bom porque tinha amizade com eles,... eu me dava bem com eles... Estou...tenho saudades! A gente se acostuma." (Helena)

Mediante esses dados podemos dizer que o ambiente do Grupo favorecia a autoconfiança e confiança no outro, a coragem de entrega, condições para contratualidade e o exercício de autonomia. Toda essa estratégia tinha a intenção de incrementar a vida cotidiana do paciente.

Mas, ao mergulharmos no cotidiano do paciente, encontramos aspectos a que qualquer um de nós está sujeito, inclusos os pacientes. 
Falamos aqui do corpo pós-moderno, contemporâneo, situado no Ocidente, por onde perpassam aspectos de um mundo que expressa uma cartografia comandada por um bombardeio maciço e aleatório de informações. Em velocidade alucinante e processadas em bits, essas informações produzidas pela mídia colaboram para uma realidade fragmentada em retalhos, compondo uma cultura do descartável, valores individualistas sustentados pela transitoriedade, efemeridade, verdades provisórias, insegurança e desamparo, que são empecilhos para a instalação e aprofundamento de emoções, relacionamentos duradouros, o que conseqüentemente pode levar a pessoa a um crescente individualismo, alienação de si mesmo e de seus próprios desejos, onde o laço social fica fragilizado e a pessoa corre o risco de se ver quase que desprovida de subjetividade. (Esper, 2004).

Segundo Esper (2004) essas mudanças aceleradas podem produzir uma sobrecarga psíquica e afetar a capacidade de decisão e adaptabilidade, ser fonte de angústia, ansiedade, frustração e outros transtornos, pois a experiência prévia, que faz parte do capital psíquico no enfrentamento das situações, passa a ter uma consistência frágil em virtude de ter que estar sempre reconfigurada, falhando na atuação de ancoragem psíquica.

Podemos pensar então, que além das dificuldades que estão sujeitos os nossos pacientes referentes à capacidade de integração dos aspectos pertinentes à própria existência corpórea, estão permeados por uma cultura e sociedade que não favorecem os aspectos integrativos. Essa somatória dificulta muitas faces da vida de quem porta transtorno mental, inclusive reforçando as condições de isolamento, alienação, desmotivação e dificuldade em estabelecer "laços" nos seus relacionamentos. Uma das nossas linhas de fuga a favor da integração da pessoa era favorecer o estabelecimento dos vínculos durante nossas sessões e promovendo o encontro da pessoa com ela mesma, através da escuta, acolhimento, exercícios corporais, dança de roda, etc.

Voltando a falar de João, houve um evento significativo em uma das sessões de RPG, quando falou que respondia sempre estar bem para tentar 
a resposta que achava que queríamos que desse, pois tinha receio que ao dar uma "resposta errada estaria atrapalhando seu tratamento e os profissionais poderiam tomar uma conduta errada para com ele." Ao ser esclarecido que esse modo de pensar não ajudava em seu tratamento e que precisávamos de sua verdadeira opinião e percepções para realmente podermos perceber os pontos em que poderíamos ajudá-lo, João voltou a "querer consertar seu pescoço". Durante esse período, percebemos que certos conteúdos apareceram especialmente nos atendimentos individuais, provavelmente pela privacidade e questionamos a participação dos pacientes e em especial de João, nos relatórios, pois seus pareceres poderiam não estar reportando uma verdade, mas sim uma tentativa de acertar, ou se adequar ao que se espera. Mesmo assim, achamos que valia a pena continuar com os relatórios e "afinar nossas observações" quanto às relações que podiam ser observadas entre os relatórios, falas e as outras expressões vindas dos pacientes.

Dentre todos os pacientes mais dois deles submeteram-se a tratamento de RPG (Reeducação Postural Global) como parte do tratamento de reabilitação. Pudemos notar que o tratamento de RPG, que era individual, permitiu os pacientes, tal como aconteceu com João, exporem questões que não colocavam quando estavam em grupo além de terem tratado das alterações posturais individuais apresentadas. Embora para essas pessoas o atendimento individual tenha resultado num fator importante para a reorganização postural e colaborador para o melhor desempenho delas no nosso Grupo, não podemos concluir que todos os pacientes necessitariam se submeter a esse tipo de atendimento.

Em função de João optamos por explorar diferentes exercícios e danças que envolvessem prioritariamente outras partes do corpo, que não a cervical, como uma estratégia para ele poder perceber que "sua pessoa era mais ampla que a cervical fletida".

Nessa ocasião, João lavava muitas vezes as mãos, relatando parecer uma mania, pois o fazia com tal freqüência que a pele das mãos estava machucada. Como estratégia optamos em incluir nos atendimentos vários 
aspectos que envolvessem as mãos: anatomia, função das mãos, exploração de movimentos e significado de gestos com as mãos. Esse modo de atendimento junto ao grupo, visou possibilitar João a ressignificar suas mãos, 're-conhecendo' significados e cuidados. Após algumas sessões as mãos estavam bem e João referiu que a mania havia passado.

Aos poucos foi descobrindo e desenvolvendo outras possibilidades corporais. O fato é que esta conduta unida aos demais atendimentos da reabilitação, ao RPG, tratamento fonoaudiológico e aplicações da toxina botulínica, Ihe ampliou a percepção corporal e, mais tarde, pudemos voltar a focar determinados exercícios para a cervical. Desta vez conseguimos resultados melhores quanto ao próprio alinhamento cervical. Parecia-nos que a ressignificação de valores por parte de João era um diferencial na sua evolução.

João encerrou sua presença no "Grupo Corpo" no final de 2004, por conta de sua participação numa oficina de papel reciclável no mesmo dia em que realizávamos nosso Grupo. No último dia de sua participação, encerrou o Grupo dizendo: "pensar e conversar, mexer o corpo me ajuda muito...esse grupo ajuda algo em meu corpo".

Hoje em dia freqüenta o CRHD em acompanhamento psicoterápico, continua as aplicações da toxina botulinica, reavaliações de RPG, acompanhamento fonoaudiológico. Tem marcha flexível com bom equilíbrio, cabeça com bom alinhamento, redução da escoliose, melhora da coordenação motora fina das mãos. Trabalha aos sábados como engraxate e durante alguns dias na semana em oficina de papeis recicláveis, pratica natação e ginástica postural, além de freqüentar um templo budista. Hoje em dia João é sorridente.

João encerra a entrevista dizendo que depois da reabilitação ficou melhor, mais independente, sem medo dos outros, mais extrovertido e termina com a seguinte fala: "ah...se a pessoa acredita que quer algo, ela consegue, mesmo que demore".

Podemos considerar que João ressignificou sua vida e que em sua trajetória, embora morasse sozinho, tivesse sofrido um transtorno mental e 
comprometimento neurológico, contou com o apoio do tio, da equipe de reabilitação do $\mathrm{CRHD}$, da equipe de reabilitação onde realiza as aplicações da toxina botulinica, assim resignificou seus valores e estabeleceu novos ordenamentos em sua vida. Atualmente ele segue com esses acompanhamentos de acordo com suas necessidades. Ele pôde e pode contar com o apoio de que nos falou Kinoshita (1996), nos seus princípios de autonomia : "... somos mais autônomos quanto mais dependentes de tantas mais coisas pudermos ser, pois isto amplia as nossas possibilidades de estabelecer novas normas, novos ordenamentos de vida". (Kinoshita, 1996, p.57). João também estabeleceu novos relacionamentos,

Outro ponto importante na terapêutica usada com João foi a visão globalista e holística (Souchard,1996), pois entendendo a pessoa em sua unidade corpo e mente realizávamos as atividades, com conseqüente intenção de alcançar efeitos motores e não motores (Gaiarsa,1991).

Essa visão beneficiou a todos os pacientes, como podemos ler nos relatos a seguir, onde os pacientes disseram que através dos exercícios em que trabalhavam com a mente e o corpo em conjunto, puderam aliviar vários tipos de dores, melhorou a auto-estima , o enfrentamento da vida e ajudou a diminuir a medicação:

"...eu tinha dor nas costelas, como se partisse em pedaço, sabe... mas depois que comecei a trabalhar exercício com você, me ajudou a... é como se esta parte do meu corpo, sabe o que é regenerar? ...como se tivesse um fator de cura, sabe,... que curasse todos tipos de dores, dores mentais, dores da cabeça, tipo como te falei, convulsão, enxaqueca, tontura, pressão alta, pressão baixa, dor de cabeça. Quando comecei a trabalhar com o corpo e a mente, melhorei, melhorei muito, então é isso!...sou mais forte pra enfrentar a vida lá fora.. , me ajudou muito a melhorar a auto-estima e eu acho que eu sou outra pessoa, hoje eu sou uma pessoa lá fora, tô fazendo coisas que eu nunca fiz, coisas maravilhosas que eu sempre quis ter na vida, é sair, fazer amizades, fazer exercícios físico, eu devo isso a você.." (Mario)

“... Eu acho que com os exercícios até evitou que eu tomasse muito remédio, que fosse muito akineton sabe, porque...quando eu esquecia de tomar o remédio, eu já ficava travada, eu não sei se era psicológico ou era da coluna mesmo, aí evitou que 
eu tomasse mais e mais remédio, porque não foi uma combinação de muitos remédios como foi das outras vezes, já tomei sertralina e outros bem fortes ..., aí agora eu só tomo um que é fraquinho, tomei coisas bem pesadas, ziprexa que eu ficava sonhando colorido, então acho que evitou que eu tomasse muita coisa, eu sei que estou melhorando." (Rita)

\section{Outros benefícios também foram referidos:}

"Ajudou, é... Não sei se você lembra que eu costumava dar aula de defesa pessoal, me ajudou muito né! quer dizer, não é somente aula de luta que me ajudou mas sim os outros exercícios pelo qual você passou pra todos os pacientes e pra mim né!... aquele que eu era antigamente... como eu era, ficava só na cama, desanimado, jogado, não queria enfrentar o dia lá fora, ver as pessoas andando ou fazendo amizade ou fazer caminhada. Agora hoje não, hoje eu saio direto vejo gente, faço exercício, agora que eu moro em apartamento, em prédio, tem uma quadra lá, eu fico fazendo Cooper, lá no prédio, dou uma volta no prédio, faço exercício assim, faço um monte de coisas, né! Faço tudo...Agora, o "Grupo Corpo" pode ir ajudando milhares de pessoas que tem essa doença mental, ou uma doença física, assim sei lá, pode ajudar muita gente .." (Mario)

"Ah...sim, acho que ajuda porque é uma terapia. A gente aprende o nome dos ossos da mão, dos pés... Acho, acho importante a pessoa saber o nome dos ossos....É...curiosidade...eu mesmo não sabia como era o nome dos ossos das mãos dos pés" (Maria )

"Ah... sobre a sexualidade achei importante saber isso...alguma coisa eu sabia...e alguma coisa não...foi bom..a pessoa precisa estar informada..aqui aprendi a pensar em mim mesma" (Helena)

"Ajudou, ajuda a diminuir as manias.." (Helena)

"No "Grupo Corpo" aprendi a soltar a coluna"(Rita)

Durante as entrevistas, ao solicitarmos aos pacientes quanto à sugestões para o "Grupo Corpo", encontramos diferentes desejos e opiniões, que se convergiram em dar continuidade ao Grupo, realizar exercícios que 
envolvam a mente, o corpo, que estimulem a memória e sobretudo que continuemos dançando:

"...fazer os exercícios antes de dançar, o corpo melhora, explicar os ossos e o esqueleto, outro dia falar outra coisa do corpo, para aprender. Quando eu posso lembrar da infância, daí melhora a cabeça, vai memorizando e lembrando seu passado, pra melhorar a mente. Eu acho que tem alguns pacientes que eu acho que não se lembram bem do seu passado, por exemplo eu sou um, quando vc foi explicando eu fui lembrando, lembrava o que aprendi na infância, a mente ia melhorando. Se o paciente lembrava o que fez a semana passada também melhora a mente." (João)

"...eu saia sempre melhor do grupo, mais leve, outra pessoa...mexer o corpo e dançar pode ajudar muita gente." (Mario)

“... se tivesse um grupo só de dança eu voltaria!" (Lúcia)

Ao percebermos que em várias ocasiões os pacientes conseguiam se sentir melhor após as atividades que realizávamos, servia-nos de grande estimulo. Devemos lembrar que não eram quaisquer exercícios, mas exercícios agregados à consciência corporal, conversas e dança. Notávamos que o aspecto lúdico agradava e colaborava para que os pacientes se interessassem e enfrentassem os temas mais difíceis de serem vivenciados por eles.

Apesar da maioria ter relatado na entrevista seu aproveitamento no nosso grupo, um dos pacientes referiu não ter aproveitado muito o "Grupo Corpo", justificada pela grande ansiedade que sentia, visto que já chegava nervosa e o tempo todo ficava interessada em saber o que os outros participantes tinham trazido para comer e beber:

“..eu chegava nervosa e ansiosa por causa de conflitos familiares... eu era muito ansiosa, eu era ansiosa sim, até que eu perguntava no grupo o quê que ia ter de comer, o quê que ia ter de beber... agora eu lembrei , não tinha um dia que eu não perguntava, um dia que eu não...por isso que eu não aproveitava muito o grupo, por causa da ansiedade." (Simone) 
O Grupo como um todo percebia a ansiedade referida por Simone. Segundo Bang (1991), a música e a dança enquanto trabalhos corporais , além de trabalhar aspectos ligados ao físico, podem diminuir a ansiedade, a raiva, a tristeza, dentre outro. Usávamos esses meios com Simone. Embora ela registrasse em seus relatórios que sai "menos ansiosa, mais tranqüila" e percebíamos isso no seu ritmo menos acelerado de andar e falar, para ela de algum modo, não houve um aproveitamento a seu contento no Grupo, pois a mesma relata isso na entrevista. Apesar da sensação de falta de aproveitamento referida por Simone, ela participava do Grupo em todas as atividades propostas e saia relatando sentir-se muito bem ao final das sessões, que corroborava com nossas observações. De qualquer modo, mesmo que algo esteja nos escapando aqui, a ansiedade é um aspecto relevante e presente em Simone, pois ao sair da entrevista pude observar seu ritmo acelerado em se movimentar, especialmente para andar.

Essa análise nos mostrou que o "Grupo Corpo" contribuiu para o desenvolvimento pessoal dos pacientes. A partir de um trabalho corporal ocasionou efeitos motores e não motores, que contribuíram para o incremento da contratualidade e exercício de autonomia para os pacientes.

\subsection{ANÁLISE DAS ENTREVISTAS COM OS PROFISSIONAIS}

À medida que a pesquisa se desenvolveu, percebemos quão pretensioso seria chegar a um aprofundamento da análise das entrevistas com os profissionais. Inseridos no projeto mais amplo de reabilitação do CRHD, os profissionais forneceram dados não apenas sobre o "Grupo Corpo" que mereceriam ser objeto de estudo de uma pesquisa exclusiva, visto a amplitude e riqueza de dados.

Porém, as entrevistas com os profissionais também permitiram uma compreensão do significado do "Grupo Corpo" para o projeto de reabilitação dos usuários, na perspectiva dos trabalhadores da equipe interdisciplinar.

Poderíamos também ter optado em realizá-la em detrimento das entrevistas com os pacientes, o que não foi a opção escolhida, pois os 
pacientes são o objeto principal da reabilitação e ímpares na contribuição para as respostas das inquietações suscitadas na autora nesse trabalho.

Um primeiro aspecto mencionado por vários dos profissionais entrevistados referiu-se à origem e ao "lugar de importância" do "Grupo Corpo" na história do projeto de reabilitação do CRHD. Constatamos que os profissionais consideravam importante realizar um trabalho corporal com os pacientes, lembraram de tentativas anteriores ao "Grupo Corpo", e justificaram de diferentes formas a necessidade dessa modalidade de trabalho.

".... desde o grupo de educação física, que foi pioneiro aqui, e tendo a certeza de que a atividade física ou atividade corporal contribuía para a questão da reabilitação ou o desenvolvimento de um potencial do paciente que a gente começou a fazer um trabalho com a atividade física, depois que veio o grupo de massoterapia, o grupo T.O.C.A.R..

E aí veio o grupo com a questão da dança também, dança e percepção corporal, consciência corporal, aí veio o "Grupo Corpo"... Com a formação do "Grupo Corpo"... veio a incrementar...a abordagem da questão corporal, desde a questão do esqueleto, desde uma visualização, uma aula do corpo humano e pra chegar na questão da conscientização corporal. Eu acho fantástico isso daí, isso daí tem tudo haver com o princípio de que a mente e o corpo não são dissociados.... A questão do esporte eu já presenciei fazendo com que o paciente volte para a realidade, então a questão corporal é super importante, na contribuição conjunta com os grupos verbais, digamos assim, pra gente tentar alguma coisa com o paciente com transtorno mental... eu acho que é super importante a questão da conscientização corporal...em conjunto com as outras atividades, eu acho isso." (Nelson)

"...o "Grupo Corpo" veio a acrescentar o que a gente pensava que poderia estar ajudando, principalmente os nossos pacientes a reconhecerem o próprio corpo. .." (Roberto)

"a questão do corpo no CRHD, ele vem desde... um grupo só de dança circular...daí veio o "Grupo Corpo"...No HD que eu trabalhava a gente nunca mexeu com o corpo dessa forma, e eu achei uma conquista grande, foi uma coisa que veio só a acrescentar nosso trabalho, e veio a mexer numa outra área que eu acho que os profissionais daqui não entrariam em contato, não trabalhariam de forma alguma 
mesmo numa outra abordagem, acho que ninguém da equipe tem esse olhar pra coisa corporal que vocês trouxeram... o quanto isso sutilmente mexe numa série de questões, o quanto eles acabam tendo mudanças corporais, esse corpo vai falando coisas... que às vezes com outros recursos você nem percebe... então eu acho que tanto é importante essa oportunidade pra eles de mexer numa outra área que não é só emocional e mental e trazer pro corpo, quanto pra equipe, pro trabalho, pra saúde mental se ampliando... Hoje eu pensando em outras coisas que eu faço e outras coisas que reflito... me vem essa coisa do quanto a gente às vezes tem que sair mais ainda do verbal e sair até às vezes do fazer, da produção e trazer pra coisa que é da percepção, da sensação que é puramente corporal, e o quanto o Grupo traz isso pra mim, das pessoas poderem sentir a sua dor, o seu bem estar, sentir a força, sentir o cansaço, sentir o ritmo." (Laura)

Um segundo conjunto de pareceres dos profissionais entrevistados refere-se aos benefícios específicos do "Grupo Corpo" para os pacientes.

“...sempre a gente vê a maioria dos nossos pacientes com dificuldades e principalmente em relação ao corpo, em descobrir o seu próprio... às vezes não conseguem nem se tocar, não tem essa consciência corporal, então muitas vezes a gente vê a distorção que eles fazem disso, acho que nesse sentido veio muito a acrescentar pro nosso trabalho, porque a gente trabalha com muitas atividades terapêuticas , mas em relação ao corpo ... não era uma coisa específica você trabalhar com a consciência corporal mesmo, né." (Roberto)

"Potencializou muito o tratamento, a reabilitação do paciente aqui... eu acho super importante o "Grupo Corpo" na grade da equipe... numa questão que eu acho que é suave, que trabalha a suavidade da pessoa, em se conhecer, perceber, sentir não só o ritmo da musica mas o ritmo interno da pessoa. A questão da sociabilizacao, a interação... a gente tem a oportunidade de que isso aconteça realmente, tocando um no outro, segurando na mão, como nas danças de roda... e fundamentalmente percebendo que as pessoas podem aprender e que podem desenvolver algo que elas não sabiam e isso reforçar e desenvolver a auto estima, que nos nossos pacientes se existe é muito baixa... Potencializar ou fazer com que o paciente veja sua parte sadia, porque a maioria dos tratamentos vêem somente a doença, como 
atacar a doença... e todo mundo tem potencial, qualquer um , o mais complicado aprende alguma coisa, desenvolve alguma coisa ou recorda alguma coisa, então eu acho que todos ali tem sua parcela: uma pecinha do quebra cabeça." (Nelson)

"...O "Grupo Corpo" faz... uma retomada do corpo... como se dissesse inscrição do sujeito nesse corpo... esse corpo é meu, esse corpo funciona assim, eu tenho essa postura... ver e se reconhecer... à medida que você desperta esse paciente pra... um corpo que não é só um corpo carne... mas um corpo que foi vivo pelo outro, um corpo que foi tocado por uma mãe, quando era pequeno que ouvia uma melodia ou não: o individuo desprovido disso... quando você trabalha ao mesmo tempo com todas essas questões sem duvida a possibilidade de você retomar... e acho que uma das questões prioritárias nesse trabalho é poder indicá-los pra própria vida, poder tomar decisão, um trabalho de desalienação, pra poder tomar posse da sua vida, das suas vontade, do seu corpo. Acho que é um pouco isso, esse Grupo contribui ao mesmo tempo, com suas particularidades... um efeito de um trabalho em conjunto." (Fernanda)

“... creio que atende a todos os critérios dos outros grupos, por exemplo ...do paciente ser mais solto... de estimular a participação, acho que é reabilitação total, assim faz parte, inclusive integrando uma coisa que geralmente a reabilitação deixa de lado, na maioria dos lugares isso é deixado de lado mesmo. O pessoal se preocupa tanto com outras questões de assertividade do paciente, de iniciativa, que e isso é deixado de lado, só que através disso pode-se chegar no resto, eu acho que através de um trabalho com o corpo, dá pro paciente chegar e ter mais iniciativa...ter mais contato com as pessoas, eu acho importantíssimo." (Clara)

"...é como se recuperasse a parte perdida que a doença mental ocasionou contribuindo assim pra reabilitação psicossocial deles." (Antonio)

"Eu acho um Grupo importante.... eu acho um grupo que à medida que integra o paciente corporalmente. À medida que os indivíduos que estão com seqüelas de surtos psicóticos medicados, em geral têm a 
psicomotricidade e a movimentação corporal muito inibida, e a própria doença faz com que eles adquiram posturas viciosas, posturas defensivas. Ã medida em que ele adquire uma conscientização maior ele pode estar enfrentado e corrigindo as posturas e corrigindo as posturas sem dúvidas que isso dá um outro contato com o mundo exterior." ( Mauro)

“...quando estou vendo o paciente estou pensando no paciente ....estou pensando indicações, é um trabalho sinérgico, quando estou prescrevendo uma medicação ou se eu tenho uma possibilidade de intervenção onde o paciente se sinta mais acolhido, mais relaxado, menos estressado emocionalmente em função de um trabalho corporal. Se ele adquire uma tolerância maior, uma fronteira maior entre o interno e o externo em função de um trabalho corporal, isso vai refletir em todas as outras intervenções que eu estou cogitando para ele que por ventura ele possa estar fazendo... vai interferir em algum tipo de medicação, quantidade de medicação, oportunidade da medicação, dose da medicação, por exemplo. , então vai havendo uma sinergia dos processos ... acompanhando a condição clinica do cliente ao longo de sua historia, então eu não consigo pensar a minha prática isolada disso." (Eduardo)

“...O "Grupo Corpo" dando conscientização corporal pode melhorar uma performance esportiva, embora não seja o objetivo do Grupo: performance, pode melhorar a percepção do individuo na relação dele com os outros, no espaço... mas isso também vai refletir no jeito que ele se posiciona em outras áreas que não sejam físicas... (Eduardo)

Alguns profissionais contaram a origem do "Grupo Corpo", que nascido do Grupo de Dança, agregou ao trabalho já existente a abordagem fisioterápica e usaram algumas palavras como, "acrescentar", "incrementar", "ampliação", "potencialização", para nomear o significado dos efeitos do "Grupo Corpo" para a equipe e os trabalhos por eles realizados. Também contaram que na ocasião em que surgiu o "Grupo Corpo", sentiam falta de uma abordagem ligada ao reconhecimento do próprio corpo, que iria ajudar 
os pacientes e ter a possibilidade de desvelar aspectos que as abordagens verbais, por vezes não alcançam.

Esses depoimentos nos apontaram que os profissionais colocam o "Grupo Corpo" num lugar de importância que se define em complementaridade e potencialização dos trabalhos realizados pela equipe, pois relatam que através de uma prática que acolhe o paciente, olha mente $\mathrm{e}$ corpo associados, o "Grupo Corpo" aborda, sustentado na linguagem não verbal, a consciência corporal, vivências das várias sensações e percepções e que essas trazem vários benefícios tanto à equipe quanto aos pacientes, relatando que os benefícios da abordagem corporal, além de melhorarem a postura física, orientação espacial, ritmos interno e externo, integração corporal, também atingem outras áreas além da corporal, principalmente no modo de ver o mundo, na produção de autonomia e sociabilização. Outro ponto é que esta é uma das terapêuticas que, em conjunto com os demais grupos, interfere "em algum tipo de medicação, quantidade de medicação, oportunidade da medicação, dose da medicação, por exemplo", visto que trabalha 0 acolhimento, relaxamento promovendo condições para que 0 paciente se sinta "...menos estressado emocionalmente em função de um trabalho corporal"..

Desse modo, a abordagem corporal que veio a preencher uma lacuna, sentida pelos profissionais da equipe, é um trabalho que parte do físico, e alcança áreas não físicas trazendo benefícios para os pacientes.

Para isso consideramos que o primeiro ponto é o da escuta do paciente e do entendimento de que corpo e mente formam uma unidade, são indivisíveis. (Gaiarsa, 1991; Bertazzo,1996): olhar holístico; e que os músculos funcionam organizados em cadeias musculares: olhar globalista. (Souchard,1996). Expressam o tempo todo, compondo uma linguagem não verbal de comunicação (Davis,1979). Essa linguagem está presente nas posturas e nos gestos dos pacientes, que muitas vezes estão alterados em função de tentarem esconder ou não entrarem em contato com uma dor, quer seja física e/ou emocional (Piret, Bèzieres, 1992). 
O segundo ponto é que realizamos um trabalho corporal que permite o contato com a dor e/ou estado de sofrimento, para transformá-lo (s) e mudar posturas e os gestos. Para isso usamos exercícios físicos e acolhimento. Rolnik (1995) fala do sentido de se deixar entrar num pouquinho de caos, para depois sairmos transformados e diz que ao nos sentirmos acolhidos, confiamos e nos entregarmos.

A condição de acolhimento terapêutica tem a função de gerar o apoio que o paciente necessita para buscar novos rumos, tomar decisões e exercitar sua autonomia (Kinoshita,1996), pois sente que pode contar com os profissionais. À idéia de entrar num pouquinho de caos podemos relacionar os princípios de desconstrução (Sarraceno, 1996), para dar a possibilidade do paciente desconstruir, reconstruir posturas, gestos e ressignificar sua consciência corporal. Quando construímos posturas e gestos melhores, distribuímos melhor a força da gravidade, o que diminui tensões e dores musculares e ocasiona bem estar, fatores que vão interferir nos modos de sentir, pensar e interagir com o mundo . (Gaiarsa, 1996).

Maffesoli (2005) complementa essa idéia ao considerar que ao nos entregarmos, estabelecemos laços, construímos relacionamentos, sentimos que pertencemos àquele mundo, pois dificilmente a pessoa pode ser compreendida "sem uma atenção especial às relações que aí se organizam." (Greiner, 2005, p.23). Para isso é necessário que o paciente esteja presente naquele momento, e quanto mais ele se identificar com as propostas das atividades, mais estará motivado em participar. Fluirá melhor ao escolher caminhos que têm haver com ele.

Em linhas gerais, é desse modo que o "Grupo Corpo" alcançou os benefícios aos pacientes e potencializou os trabalhos da equipe.

Podemos considerar que segundo os depoimentos dos profissionais, o "Grupo Corpo" preencheu uma lacuna desejada por eles e que é sinérgico ao trabalho dessa equipe.

Após apontarem a sinergia entre o "Grupo Corpo" e a equipe de reabilitação, houve sugestões quanto à articulação/integração do "Grupo Corpo" com os demais grupos. 
Segundo a manifestação de alguns trabalhadores, há necessidade de uma maior integração do "Grupo Corpo" com os demais, o que aconteceria caso ele fosse oferecido em outro dia da semana, visto que as sextas-feiras os pacientes têm presença facultativa, o que dá a conotação de lazer e é o dia em que o "Grupo Corpo" realiza suas atividades.

“... ainda falta uma integração do "Grupo Corpo"... talvez até pelo dia que ele acontece... acho que acabou ficando na cabeça dos pacientes, até pelo objetivo daqui, quando a gente pôs a sexta-feira pra não ter atividade terapêutica...a gente não está utilizando o "Grupo Corpo" como deveria, talvez se ele tivesse dentro da grade oficial em outro dia da semana, ele fosse completamente diferente... então, não pensa que a gente não fala pra eles que tem horário que tem que vir, mas é uma coisa que ficou cristalizado: sexta-feira é pra eu vir se eu quiser." (Mônica)

"Primeiro ele deveria ser para todos os pacientes matriculados... sem exceção. Talvez num dia em que a coisa fosse um pouco mais de rotina, porque na sextafeira é um horário que o grupo ta fora de rotina... não é obrigatório... Até que a gente perceba pra chamar a atenção demora, então é uma coisa muito mais flexível que os outros dias da semana, e isso acho que prejudica ... eu sinto ele um pouquinho fora da nossa rotina e até mais intercâmbio também, dos acontecimentos desse grupo com os outros, o que é muito difícil, não é um problema só desse grupo, eu consigo intercambio só entre os grupos que eu coordeno, e mais nenhum, e isso acho que é prejudicial... Seria bem legal a participação das famílias..." (Clara)

"Acho muito legal ter esse Grupo, é uma coisa de olhar mais pra esse Grupo, a equipe também não olha, o corpo fica uma coisa meio esquecida, não é à toa que ele está de sexta- feira, nesse horário. A gente podia se planejar, tornar obrigatório a Convivência, o corpo, alguma coisa que facilite, sei lá! A gente pode remanejar o modo de como a gente ta lidando com essa sexta-feira." (Fernanda)

Ao levantar essa falta de integração do "Grupo Corpo" com os demais grupos da equipe também veio à tona 0 desejo de integração entre os grupos em geral, pautado na importância de um trabalho que vê o paciente como um todo, que quer a troca não só entre os pacientes, mas sobretudo entre os profissionais, uma das características de uma equipe interdisciplinar. 
"Vem uma idéia não só pro "Grupo Corpo", mas em geral da gente discutir os grupos em toda reunião de equipe, o quê que tá trabalhando pelo menos... que muitas vezes é falado, mas acho que tem que ser maciço, tem que ser toda semana... então, olha a gente continua trabalhando aquilo, então vocês estão sabendo, né?!.. uma coisa informativa,... às vezes eu to trabalhando mapa para a localização de casa e não informo mais ninguém ... quando as pessoas poderiam juntar esse tema nos seus grupos... E o "Grupo Corpo" pela localização que ele ta na grade eu acho que ele fica mais prejudicado ainda, mas era mais de integrar mesmo, de tornar pra todos, uma participação mais controlada deles e integrar com os outros." (Fernanda)

“... seria mais legal se a gente pudesse estar mais tempo, outros dias juntos... eu acho que é troca, principalmente dentro das reuniões é o que a gente pode fazer, mas assim, mesmo extra oficial, se tem alguma coisa que foi colocada e precisa ser trabalhada durante a semana..." (Clara)

" muitas vezes a gente não está necessariamente muito integrado então acho importante assim... que muitas vezes a gente perde porque tem um monte de coisas acontecendo aqui ao mesmo tempo, tem uma demanda infinita de ... os grupos não estão tão casados ... É uma questão de falar o que é que você acha ... discutir em reunião ...vamos fazer uma complementação... porque também tem que ter uma proximidade... Mas à medida que você sente, você diz, puxa, isso vai ser legal pra continuar em tal grupo... ou me pega e fala :- oh ...estou trabalhando tal coisa , informar qualquer um que você acha que tem haver. Às vezes falta isso de fazer uma ponte... mas às vezes os grupos acontecem à tanto tempo e formam aí esse bolo mas que às vezes a gente acaba não precisando exatamente mais o que está acontecendo exatamente em que momento em que está aquele grupo. Isso é uma coisa urgente que a gente precisa fazer aqui no CRHD pra poder levar o trabalho de uma forma bem sinérgica." (Fernanda)

“...Quanto à reunião, não é um problema do "Grupo Corpo" e sim da reunião ,mais do mesmo... se isso pudesse ser feito com maior freqüência ou intensidade, tem um caminho aí pra aumento da qualidade ...de procedimento, compreensão de sentido do procedimento dentro, da evolução clinica do paciente. Mas isso não é uma coisa diferente, é mais do que já se faz, né! Aliás eu acho que a gente é uma equipe mesmo que seja de uma só pessoa, né, a gente tem vários olhares... e eu tenho que articulá-los, então se a gente não imaginar num campo mais metafórico , menos concreto cada pessoa é uma equipe né, então a gente pode pensar como uma atividade pode ser sinérgica com outra, mas em clinica esse caráter mais 
global ele tem uma presença muito visível. Se ele melhora aqui ele melhora em todo o resto e todo o resto interfere naquilo que você faz..." (Eduardo)

O desejo de maior integração, quer seja do "Grupo Corpo" com a equipe ou entre os grupos como um todo, merece atenção especial e inspira a inúmeras reflexões. No caso do "Grupo Corpo" a sugestão geral para a maior integração dele com a equipe foi a de mudá-lo de dia e colocá-lo em qualquer outro onde a presença dos pacientes não é facultativa. Mas, no caso dos demais grupos da equipe que se realizam em dias da semana favoráveis à presença dos pacientes, também há uma falta de integração.

Em resumo, a maioria dos trabalhadores sente a necessidade de uma maior integração, e procuram um espaço de troca entre os profissionais, quer seja através do aumento da freqüência, intensidade das reuniões de equipe, ou encontros informais entre os profissionais. Ao mesmo tempo justificam a falta de integração e sinergia ao acúmulo de atividades que têm em seus cotidianos. Como então, alcançar maior integração da equipe interdisciplinar? Os profissionais ainda não sabem, mas percebem a necessidade de integração e abrem espaço para reflexão.

Ao retomarmos os preceitos da reforma psiquiátrica, vemos que não há modelos a seguir, mas o exercício de descobrir novos caminhos, estratégias, e talvez aí exista uma vontade da equipe em encontrar uma outra forma de interagir, pois apesar de serem uma equipe interdisciplinar, não está havendo trocas suficientes que absorvam o potencial dos profissionais, que têm significativa experiência com pacientes com transtorno mental, pois a maioria deles está no CRHD desde a inauguração (1996) e já tinham experiência previa na área.

A equipe percebe que sua dinâmica atual não mais atende as necessidades de trocas entre os profissionais, e aponta a necessidade de maior integração e espaço para reflexão. Provavelmente a dinâmica atual esteja relacionada a estratégias já conhecidas, que vem sendo repetida à muito tempo e por isso facilmente praticadas e conseqüentemente difícil de serem mudadas, pois estão todos (ou quase todos) da equipe muito envolvidos e "engrenados" nelas. Essa situação traz as palavras de 
Sarraceno (1996), que representam as idéias de Basaglia, quando diz que ao desejarmos mudanças em nossos pacientes, em nossas estratégias, também precisamos mudar. Podemos dizer então, que a mudança não começa no outro ou no grupo, mas em si mesmo.

Pode ser que esse seja o momento vivido pela equipe: refletir e mudar. Esse momento pode estar representado na "lógica movediça" de Maffesoli (2005).

Segundo a "lógica movediça", ao deixarmos para trás o que nos é familiar e nos dá sensação de segurança (por exemplo, as múltiplas estratégias que cotidianamente são usadas pela equipe) ingressamos em algo novo: o desconhecido. Uma aparente ou inicial insegurança ao lidarmos com o não-lógico e inusitado desconhecido, nos conduz à condição de possibilidade de escolhas, de movimentos a favor daquilo que nos é apresentado naquele momento. Encontrando aquilo que nos é afim, temos novos apoios para nos sustentar e redirecionar os modos de tratar, fazer clínica, viver no mundo. É esse novo "chão", construído pela "lógica movediça", que pode nos dar uma real segurança.

Podemos fazer uma analogia entre a "lógica movediça" e a "areia movediça": duas condições que aparentemente nos colocam numa situação vulnerável e instável, mas que nos propõem a sensação de real segurança ao seguirmos o fluxo daquele momento.

Com Cintra (2006), vemos como realmente funciona a areia movediça, erroneamente mostrada pelo cinema e pela literatura como um "chão" capaz de nos tragar até o fundo onde inevitavelmente morreremos. Um "chão" muito perigoso. Na verdade, o que ocorre na areia movediça é um fluxo ascendente de água, devido a condições peculiares da natureza, estabelecendo uma força de percolação da água (de baixo para cima) que torna nula a resistência da areia, que se transforma numa espécie de areia líquida, fazendo com que alguém sobre ela perca o equilíbrio. Mas, se essa pessoa souber nadar ou boiar na água, também vai conseguir nadar ou boiar na areia movediça, até com mais facilidade, porque a areia tem o dobro da densidade da água, o que permitirá que a pessoa nade com a metade do 
corpo para fora. Portanto, não há força interior que arraste a pessoa para o fundo da areia movediça. A pessoa pode afundar apenas se não "deixar-se ir pelo fluxo do líquido" (Cintra, 2006).

Poderíamos usar metaforicamente o real funcionamento da areia movediça comparado à lógica movediça de Maffesoli, na qual, ilusoriamente, sentimos a possibilidade de sermos "tragados" por algo instável, desconhecido, como se ao tentarmos mudar fossemos fracassar; mas, seguindo o fluxo, deixando os movimentos se orientarem segundo as condições próprias de cada um (terapeuta, paciente) para a vivência da situação inusitada, orientados pelas afinidades, pelo que nos afeta e atrai, a favor do encontro com aquilo que vibra em comum conosco, "sentimo-nos uníssonos" (Maffesoli, 2005). Algo contrário à falsa idéia, do cinema e literatura, de que entrar no tal lugar instável, na "areia movediça", seria um fatal encontro com a morte.

A mudança de paradigma proposta pela "lógica movediça" rompe a rigidez mecanicista constitutiva do processo de "saúde versus doença", deixa para trás a concepção "problema versus solução". Inaugura um novo olhar clínico, voltado para "possibilidades e probabilidades", para um novo sentido no "cuidar", marcado pela transformação dos modos de viver e sentir o sofrimento do paciente, deixando para trás o "curar" e o "resolver". (Rotelli, 1990, p. 30-33).

Assim, conforme vimos, os profissionais são favoráveis ao "Grupo Corpo" e apontam alternativas para uma maior integração. 


\section{CONSIDERAÇÕES FINAIS}

Encerrar a dissertação coloca-me de frente com a realidade de encerrar um ciclo e a vontade de fazer uma breve retrospectiva pessoal e profissional do que foi essa jornada.

Um dentro do outro, tal como Yin e Yang (Wilhelm,1997, p.228), ao mesmo tempo que encerram, os ciclos (que são cartográficos) geram e abrem possibilidades para novos pensamentos, conceitos, práticas e sugestões. É esse meu grande alento, pela minha dificuldade de achar um ponto para encerrar.

A trajetória de percorrer caminhos desconhecidos e vislumbrar um jeito diferente de fazer fisioterapia para pessoas que "aparentemente não têm um comprometimento físico e que tem um transtorno mental " foi uma grande motivação. Misturada ao movimento de busca das minhas inquietações, ousei percorrer nesses últimos anos caminhos profissionais e pessoais de desfilamento, desconstrução e resconstrução. Tal qual os conceitos de autonomia em que acredito e expus na dissertação, também precisei de apoio e acolhimento para arriscar descobrir em mim novas possibilidades e acreditar.

Senti-me inicialmente estrangeira no assunto de saúde mental, tema que não é comum para o fisioterapeuta. Encontrei dificuldades em entender para além dos aspectos classificatórios das psicoses, interessada em saber das possíveis formas em que se expressam os vários sintomas nos pacientes.

Em seguida, percebi que com algumas exceções, os pacientes apresentavam uma oscilação de humor constante durante as sessões, o que alterava a dinâmica do grupo e a participação de todos. Essas manifestações que poderiam ser produção de sintomas, agregadas ao fato da falta de assiduidade dos pacientes, direcionaram-me a repensar as estratégias de atendimento: voltei-me para criar possibilidades para que sentissem confiança, identificação, autonomia e motivação (Rolnik, 1995 ). 
Notei que uma das características da pessoa com transtorno mental grave e de longa duração é que sofre uma ruptura na sua existência, o que ocasiona danos em múltiplas áreas, corporal, social, relações interpessoais, o que faz com que sua dinâmica esteja estreitamente relacionada ao seu contexto social, o que influencia seus graus de vantagens e/ou desvantagens. Isso quer dizer que o ambiente em que ela se encontra pode ampliar ou reduzir os seus potenciais e esforços.

Essas pessoas geralmente necessitam de assistência para desenvolver aspectos do autocuidado, estão fora do mercado de trabalho, muitas vezes longe dos estudos, não conseguem seguir uma rotina: situações que favorecem o isolamento, não exercem a cidadania, "rotulam o sujeito" ao estigma de doente mental e contribuem para uma baixa auto estima observada na grande maioria dos pacientes, o que pode contribuir para uma apatia e falta de iniciativa.

Também notei que algumas vezes havia uma excessiva preocupação dos pacientes e profissionais com as questões mentais e isso colaborava para que se distanciassem das questões físicas do corpo e de suas possibilidades terapêuticas, proporcionando muitas vezes um desconhecimento de outras possibilidades de tratamento ou desconsiderando a presença de dores.

Tentar entender essa complexidade colocou-me mais próxima das pessoas que a vivem, dos profissionais que as tratam e me impulsionou a descobrir novos caminhos terapêuticos.

Parece que essa "mola propulsora" funcionou para que eu encontrasse o que chamei de "fisioterapia ampliada" e "clinica do inusitado" uma forma de ver e tratar pessoas portadoras de transtorno mental grave e de longa duração.

Essa terapêutica começava a "desmontar a relação problemasolução" (Rotelli,1990, p.28), em que o terapeuta se deslocava da lógica tendenciosa de avaliar o que era "bom ou ruim" perseguindo "resultados ótimos" para o paciente na busca de outros modos de tratar ou não tratar, com vistas à transformação do que era apresentado ali, durante a sessão, e 
quuando "a ênfase não é mais colocada no processo de "cura" mas no projeto de "invenção de saúde" (Rotelli, 1990,p. 30).

Como parte dessa "invenção da saúde", estimulávamos uma descentralização de papéis durante as sessões, nas quais os pacientes podiam coordenar várias etapas da sessão, segundo seus desejos e talentos. O respeito e consideração dos desejos e talentos dos pacientes contribuiu para o estabelecimento da confiança e entrega, para um maior compartilhamento da própria atividade entre os profissionais e pacientes, além de colocá-los na condição de aprender como qualquer pessoa, a ampliação das possibilidades de contratualidade e autonomia, visto que podiam manifestar suas vontades, necessidades e tomadas de decisão entre o grupo. Ao poderem contar com o apoio dos profissionais e dos participantes do grupo, conseguiam estabelecer novos ordenamentos, revisão de valores em suas vidas e vivenciarem estados de desalienação e autonomia, o que compactua com a idéia de autonomia de Kinoshita (1996), e como uma possibilidade de "vir-a-ser", advinda da sensação de confiança e coragem de entrega, conceitos mencionados por Rolnik (1995).

Ao iniciarmos a análise dos dados observamos que as entrevistas com os pacientes, com os trabalhadores do CRHD e os dados colhidos dos prontuários eram fontes inesgotáveis de informações, inspirações para novos estudos e que puderam evidenciar aspectos singulares quanto ao significado do "Grupo Corpo" tanto para os pacientes quanto para o projeto de reabilitação dos usuários do CRHD, sob a ótica dos trabalhadores da equipe interdisciplinar, objetivos desse estudo. Também foram inesgotáveis as conversas entre o pesquisador e os autores elencados para esse estudo; vejo ainda a necessidade de adensar esta reflexão e articulação com o referencial teórico apresentado.

Essas situações nos inspiraram a envolver as famílias numa atividade conjunta com os pacientes no grupo, em parceria com outros grupos do CRHD, o que aconteceu em 2006, quando os pacientes ensinaram aos familiares exercícios e uma coreografia. 
Atualmente, final de 2006, o "Grupo Corpo" segue seu trabalho junto aos pacientes e à equipe de reabilitação. Após 2004, não seguiu mais roteiros de atendimento, mas percorreu temas ou propostas sugeridas pelos pacientes agregadas às suas necessidades também percebidas pelos profissionais da equipe. O "Grupo Corpo" está em constante transformação e de modo dinâmico busca novos caminhos e idéias, percorrendo, como dizia Nietzsche, a "celebração da vida". 


\section{REFERÊNCIAS}

Adams L. How exercise can help people with mental health problems. Nurs Times. 1995;91(36):37-9.

Alexander FG, Selesnick ST. História da psiquiatria. $2^{\mathrm{a}}$ ed. São Paulo: IBRASA; 1980.

Amarante PDC, coordenador. Loucos pela vida: a trajetória da reforma psiquiátrica no Brasil. Rio de Janeiro: Fiocruz; 2003

Ballone G. Psicoses. In: PsiqWeb [online]. Disponível em: <http://www.psiqweb.med.br/psicoses.html>. [Acesso em 2 jul. 2005].

Bang C. Um mundo de som e música. In Ruud E. Música e Saúde. São Paulo: Sumus;1991.

Barros S, Egry EY. O louco, a loucura e alienação institucional: o ensino de enfermagem psiquiátrica sub judice. São Paulo: Cabral Editora Universitária; 2001.

Bertazzo I. Cidadão corpo. São Paulo: Sesc Ópera Prima; 1996.

Bertherat T, Abreu ES. O corpo tem suas razoes: antiginástica e consciência de si. São Paulo: Martins Fontes; 2001.

Bertherat T. A toca do Tigre. Trad. de Estela S. Abreu. São Paulo: Martins Fontes; 2002.

Braga MFL. (Re) Inventando a mulher e sua sexualidade: alteridade em tempos de AIDS... Rev CBP-RJ [periódico online]. 2000. Disponível em: http://www.cbp-rj.org.br/rev2000mulher.htm [Acesso em 20 maio 2005]. 
Barrenechea MA. Nietzsche e o corpo. In Lins D, Gadelha S. Nietzsche e Deleuze . Que pode o corpo. Rio de Janeiro: Relume Dumará; 2002.

Canesqui AM. Os estudos de antropologia da saúde/doença no Brasil na década de 1990. Ciênc Saúde Coletiva. 2003;8(1):109-24.

Cardoso CFS. Coleção Textos do Tempo. São Paulo: Papirus; 1997.

Castel R. A ordem psiquiátrica: a idade de ouro do alienismo. Rio de Janeiro: Graal; 1978.

Castro E. A apropriação de si mesmo através da dança [dissertação]. São Paulo: Escola de Artes e Comunicação da USP; 1992.

Conselho Nacional de Saúde. Resolução n. 196, de 10 de outubro de 1996. Diretrizes e normas regulamentadoras de pesquisas em seres humanos. Bioética. 1996;4(2 Supl):15-25.

Davis F. A comunicação não verbal. São Paulo: Sumus; 1979.

Delisa JA, Martin GM, Currie DM. Medicina de reabilitação: passado, presente e futuro. Trad. de Lilia B. Ribeiro e Vilma R. S. Vargas. São Paulo: Manole; 1992.

Donice MG. A análise bioenergética [online]. Disponível em: http://www.saudevidaonline.com.br/index.htm. [Acesso em 10 jun 2006].

Edelman GM. Biologia da consciência: as raízes do pensamento. Lisboa: Instituo Piaget; 1992.

Esper BEM, Neder M. O corpo contemporâneo. In: Anais da Convenção Brasil Latino América; Congresso Brasileiro e Encontro Paranaense de Psicoterapias Corporais; 2004; Foz do Iguaçu, PR [online]. Foz do Iguaçu: 
Centro Reichiano; 2004. Disponível em: http://www. centroreichiano.com.br/artigos/anais/br. [Acesso em 10 mar. 2006].

Faria EL. Idade Média, 1999-2005 [online]. Disponivel em: http://www.nomismatike.hpg.ig.com.br/ldadeMedia.html. [Acesso em 4 set. 2005].

Figueiredo Junior MM. Esquizofrenia e reabilitação psicossocial: perspectivas teóricas e praticas [dissertação]. São Paulo: Faculdade de Medicina da USP; 1996.

Frohne I. Musicoterapia na educação social e na psiquiatria . In Ruud E. Música e Saúde. São Paulo: Sumus; 1991.

Furtado JP. A fisioterapia na saúde mental. Fisioter Mov. 1995;8(1):13-24.

Gaiarsa JA. O corpo e a terra. São Paulo: Ícone; 1991.

Gonzáles Mas R. Tratado de reahabilitación medica. Barcelona: Editorial Científico-Médico; 1965. Tomo 1.

Greiner C. O corpo: pistas para estudos indisciplinares. São Paulo: Annablume; 2005.

Greiner C, Amorim C. Leituras do corpo. São Paulo: Annablume; 2003.

Guirard P. A linguagem do corpo. Trad. de Lólio L. de Oliveira. São Paulo: Ática; 1991.

Haguette MTF. Metodologias qualitativas na sociologia. $3^{\underline{a}}$ ed. Petrópolis: Vozes; 1995. 
Hesso R. Physical activity in the treatment of mental disorders. Scandinavian J Social Med. 1982;29 Suppl:259-64.

Keil I, Tibui M. Diálogos sobre o corpo. Porto Alegre: Escritos; 2004.

Keleman S. Mito e corpo: uma conversa com Joseph Campbell. São Paulo: Sumus; 2001.

Langslet RL. Discurso de abertura. Simpósio "Música e Saúde". In Ruud E. Música e Saúde . São Paulo: Sumus; 1991.

Lins D, Gadelha S. Nietzsche e Deleuze: que pode o corpo. Rio de Janeiro: Relume Dumará; 2002.

Lira GV. Avaliação da ação educativa em saúde na perspectiva compreensiva: o caso da Hanseníase [dissertação]. Fortaleza: Universidade Federal do Ceará; 2003.

Lowen A. Bioenergética. 5a ed. São Paulo: Sumus; 1975.

Lyra B, Santana G. Corpo e mídia. São Paulo: Arte e Ciência; 2003.

Louza Neto MRL, Motta T, Wang Y, Elkis H. Psiquiatria básica. Porto Alegre: Artes Médicas; 1995.

Ludke M, André MEDA. Pesquisa em educação: abordagens qualitativas. São Paulo: EPU; 1986.

Maffesoli M. O mistério da conjunção: ensaios sobre comunicação, corpo e socialidade. Trad. de Juremir M. da Silva. Porto Alegre: Sulina; 2005. 
Marinho LCP, Miolo SB. Ação fisioterápica às necessidades do portador de sofrimento psíquico. Fisioter Mov. 1997;10(2):44-52.

Martinsen EW, Sandvik L, Kolbjornsrud O. Aerobic exercicies in the treatment of non-psychotical mental disorders an exploratory study. Nord Psykiatr Tidss (Oslo).1989;43:521-9.

Minayo MCS. O desafio do conhecimento: pesquisa qualitativa em saúde. São Paulo: Hucitec; 2004.

Monteiro PP. Quem somos nós. Belo Horizonte: Gutemberg; 2004.

Munhoz CPM. Atuação fisioterápica em pacientes com transtornos mentais: terapia corporal e bioenergética. Rev Psiq Clín. 1996;23(3):115-22.

Oliveira IB. "Fora da higiene não há salvação": a disciplinarização do corpo pelo discurso médico no Brasil Republicano. MNEME Rev Humanidades [periódico online]. 2003;4(7):1-12. Disponível em: http://www.seol.com.br/mneme/ [Acesso em 12 ago. 2005].

Oliveira MAF. Do canto (lugar) maldito ao porto (lugar) seguro: representações do manicômio. São Paulo: Selecta; 2000.

Ossona A. A educação pela dança. São Paulo: Sumus; 1988.

Pauli E. Enciclopédia de Filosofia [online]. Florianópolis; 1997. Disponivel em: www.consciencia.org/links.shtml [Acesso em 5 jul. 2005].

Piret S, Béziers MM. A coordenação motora: aspecto mecânico da organização psicomotora do homem. São Paulo: Sumos; 1992.

Perrusi A. Imagens da loucura: representação social da doença mental na psiquiatria. São Paulo: Cortez; 1995. 
Reich W. A análise do caráter. São Paulo: Martins Fontes; 2001.

Ressel LB, Gualda DMR, Gonzalez RMB. Grupo focal como uma estratégia para coletar dados de pesquisa em enfermagem. Intern J Qual Methods. 2002;1(2). Disponível em: http://www.ualberta.ca/ ijqm. [Acesso em 12 ago. 2005].

Rezende H. Cidadania e loucura. Petrópolis: Vozes; 1987.

Riessman CK. Narrative analysis: qualitative research methods. London: Sage; 1993.

Rolnik S. Hall Harthey e a ética da confiança. Cad Subj. 1995;1(3):65-74.

Rotelli F. Psiquiatria negada. In Nicácio MFS. Desinstitucionalização. São Paulo: Hucitec; 1990.

Sachs ML. Running therapy for the depressed client. Top Clin Nurs. $1981 ; 3(2): 77-86$.

Sarraceno B. Reabilitação psicossocial: uma estratégia para a passagem do milênio. In: Pitta A. Reabilitação social no Brasil. $2^{\underline{a}}$ ed. São Paulo: Hucitec; 1996. p. 13-8.

Shestack R. Fisioterapia Prática. Trad. de Patrícia L. V. Pinho. $3^{\underline{a}}$ ed. São Paulo: Manole; 1987.

Silva AM. Elementos para compreender a modernidade do corpo numa sociedade racional. Cad CEDES [periódico online]. 1999;19(48):1-14. Disponível em: http://aaa.unifap.br/adalberto/artigo3.htm. [Acesso em 12 ago. 2005]. 
Silva ATMC, Barros S, Oliveira MAF. Políticas de saúde mental no Brasil: a exclusão/inclusão social como intenção e gesto. Rev Esc Enferm USP. 2002;36(1):4-9.

Silva DGV, Trentini M. Narrativas como técnica de pesquisa em enfermagem. Rev Lat Am Enferm. 2002;10(3):423-32.

Silva MJP. Comunicação tem remédio: a comunicação nas relações interpessoais em saúde. São Paulo: Gente; 1996.

Souchard PHE. "Reeducação e Tradição". Rev Bras RPG. 1996;1(1):28-9.

Souchard PH E. O streching global ativo. Trad. de Sonia Pardelas. São Paulo: Manole; 1996.

Telles I. O livro das transformações. São Paulo: Agora; 2004.

Triviños NSA. Introdução à pesquisa em ciências sociais. São Paulo: Atlas; 1987.

Vasconcelos EM. Complexidade e pesquisa interdisciplinar: epistemologia e metodologia operativa. $2^{\underline{a}}$ ed. Rio de Janeiro: Vozes; 2004.

Veale DMC. Exercice and mental health. Acta Psychiatr Scand. 1987;76(2):113-20.

Wilhelm R. I Ching o livro das mutações. 16 ed. São Paulo: Pensamento; 1997. 


\section{ANEXO I \\ Termo de consentimento para o paciente}

\section{Termo de consentimento livre e esclarecido}

Meu nome é Eliana, fisioterapeuta, e estou realizando uma pesquisa no programa de Pós-Graduação nível mestrado sob a orientação da professora Lúciana de Almeida Colvero da Escola de Enfermagem da USP. O título provisório é: "Os Talentos do Corpo: uma experiência corporal com pacientes com transtorno mental". Esta pesquisa tem o objetivo de saber se as atividades que realizamos no "Grupo Corpo", durante o ano de 2004, contribuíram para o seu tratamento no CRHD. Para isso gostaríamos de convidá-lo a participar de uma entrevista, que será marcada numa data e local que permita o seu comparecimento. Solicitamos também de sua autorização para coletar os dados contidos em seu prontuário, que possam colaborar para o desenvolvimento desta pesquisa.

Para a pesquisa será garantido o seu anonimato. Você tem total liberdade de participar ou de recusar além de poder retirar seu consentimento a qualquer momento da pesquisa, sem que isso implique em penalização ou prejuízo no seu tratamento.

Caso concorde em participar, gostaria da sua permissão para gravar a entrevista.

Os resultados serão divulgados em publicações posteriores ainda assegurando $o$ anonimato dos participantes.

Em caso de dúvida, me prontifico a esclarecer.

Você gostaria de participar?

obrigada.

\section{Pesquisadora}

Eliana C.T. Bomente

Escola de Enfermagem da Universidade de São Paulo Av. Dr. Enéas de Carvalho Aguiar, 419. Fones: 3066-7601 / 3066-7548 
Declaro ter sido esclarecido a respeito do objetivo, da forma de participação e de utilização das informações e quanto à liberdade de recusar ou de interromper, sem ônus de qualquer espécie, minha colaboração durante a investigação que está sendo realizada pela aluna Eliana C.T. Bomente.

Concordo em participar como informante na coleta de dados para essa investigação.

Nome e assinatura

Fone: 


\section{ANEXO II \\ Termo de consentimento para o profissional}

\section{Termo de consentimento livre e esclarecido}

Meu nome é Eliana, fisioterapeuta, e estou realizando uma pesquisa no programa de Pós-Graduação nível mestrado sob a orientação da professora Lúciana de Almeida Colvero da Escola de Enfermagem da USP. O título provisório é: "Os Talentos do Corpo: uma experiência corporal com pacientes com transtorno mental". O presente estudo busca conhecer as contribuições da abordagem corporal para as pessoas com transtorno mental crônico em processo de reabilitação no CRHD, durante o ano de 2004. Para isso gostaríamos de convidá-lo a participar de uma entrevista, que será marcada numa data e local que permita o seu comparecimento. Solicitamos também de sua autorização para coletar os dados contidos em seu prontuário, que possam colaborar para o desenvolvimento desta pesquisa.

Para a pesquisa será garantido o seu anonimato. Você tem total liberdade de participar ou de recusar além de poder retirar seu consentimento a qualquer momento da pesquisa, sem que isso implique em penalização ou prejuízo no seu tratamento.

Caso concorde em participar, gostaria da sua permissão para gravar a entrevista.

Os resultados serão divulgados em publicações posteriores ainda assegurando $o$ anonimato dos participantes.

Em caso de dúvida, me prontifico a esclarecer.

Você gostaria de participar?

obrigada.

\section{Pesquisadora}

Eliana C.Tessitore

Escola de Enfermagem da Universidade de São Paulo Av. Dr. Enéas de Carvalho Aguiar, 419. Fones: 3066-7601 / 3066-7548 
Declaro ter sido esclarecido a respeito do objetivo, da forma de participação e de utilização das informações e quanto à liberdade de recusar ou de interromper, sem ônus de qualquer espécie, minha colaboração durante a investigação que está sendo realizada pela aluna Eliana C.T. Bomente.

Concordo em participar como informante na coleta de dados para essa investigação.

Nome e assinatura

Fone: 


\section{ANEXO III \\ Roteiro da entrevista com o paciente}

\section{I- IDENTIFICAÇÃO}

1.Dados Pessoais

- Nome completo:

- Sexo:

- Idade:

- RGHC:

2. Endereço atual

Rua:

Número:

Bairro:

Cidade:

Estado:

Cep:

Telefone:

3. História de vida

Escolaridade:

Profissão:

Ocupação:

Reside com quem?

\section{II - Questões norteadoras}

1. Para você, o que é o "Grupo Corpo"?

2. O que realizamos nele?

3. Para que serve?

4. O que você achou por ter participado dele?

5. Você acha que ele colaborou para o seu tratamento no CRHD? E para seu dia a dia?

6. Você gostaria de dar suas sugestões para a continuidade deste Grupo?

7. Você recomendaria este Grupo a alguém? Quem? 


\section{ANEXO IV \\ Roteiro da entrevista com o profissional}

\section{I . IDENTIFICAÇÃO}

1. Dados Pessoais

Nome completo:

Sexo: Idade: RGHC:

2. Endereço atual

Rua:

Número:

Bairro:

Cidade:

Estado:

Cep:

Telefone:

3. História de vida

- Formação profissional:

- Data da conclusão do curso:

- Tempo que trabalha com pacientes com transtorno mental:

- Tempo de trabalho no CRHD:

- Outra formação: sim ou não. Se sim qual ou quais?

- Grupos atende pacientes no CRHD

II - Questões norteadoras

1. Para você o que é o "Grupo Corpo"?

2. Para você qual é a proposta do o "Grupo Corpo"?

3. Você percebe alguma contribuição do "Grupo Corpo" durante o desenvolvimento de suas atividades junto aos usuários. Sim - Não. Se sim quais.

4. Você percebe alguma contribuição do "Grupo Corpo" junto aos usuários fora de seu espaço terapêutico - nos espaços informais do CRHD. Sim - Não. Se sim, quais.

5. Para você o "Grupo Corpo" contribui para o projeto de reabilitação do CRHD. Sim - Não. Se sim, diga como.

Você teria sugestões para a continuidade do "Grupo Corpo"? 


\begin{abstract}
ANEXO V
Roteiro dos relatórios dos pacientes no inicio e final da sessão
\end{abstract}

1. Como você se sente nesse momento?

2. Quais suas sensações corporais nesse momento? 


\section{ANEXO VI}

Aprovação do Comitê de Ética 


\section{ANEXO VII}

Aprovação do Comitê de Ética 